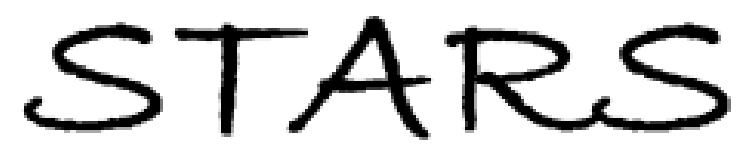

University of Central Florida

STARS

9-1-2016

\title{
Final Report: Cooling Seasonal Energy And Peak Demand Impacts Of Improved Duct Insulation On Fixed-Capacity (SEER 13) And Variable-Capacity (SEER 22) Heat Pumps
}

Florida Solar Energy Center

Charles Withers, Jr.

Florida Solar Energy Center, chuck@fsec.ucf.edu

Part of the Energy Systems Commons

Find similar works at: https://stars.library.ucf.edu/fsec

University of Central Florida Libraries http://library.ucf.edu

This Contract Report is brought to you for free and open access by STARS. It has been accepted for inclusion in FSEC Energy Research Center ${ }^{\circledR}$ by an authorized administrator of STARS. For more information, please contact

STARS@ucf.edu.

\section{STARS Citation}

Florida Solar Energy Center and Withers, Jr., Charles, "Final Report: Cooling Seasonal Energy And Peak Demand Impacts Of Improved Duct Insulation On Fixed-Capacity (SEER 13) And Variable-Capacity (SEER 22) Heat Pumps" (2016). FSEC Energy Research Center®. 109.

https://stars.library.ucf.edu/fsec/109

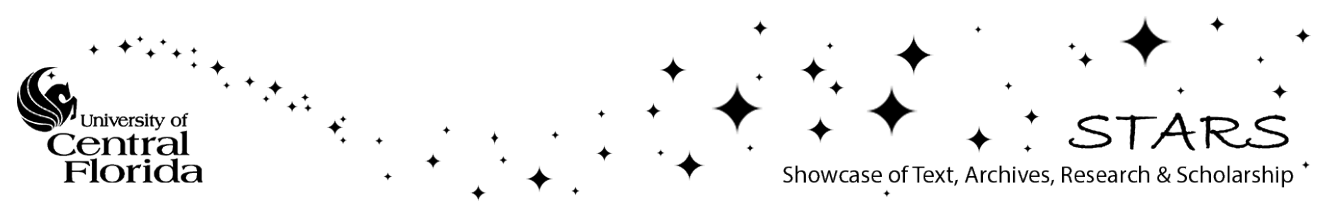




\section{FLORIDA SOLAR ENERGY CENTER \\ Creating Energy Independence}

\section{Final Report: Cooling Seasonal Energy and Peak Demand Impacts of Improved Duct Insulation on Fixed- Capacity (SEER 13) and Variable- Capacity (SEER 22) Heat Pumps}

FSEC-CR-2039-16

Final Report

September 2016

Authors

Charles Withers Jr. James Cummings Bereket Nigusse 


\section{Disclaimer}

The Florida Solar Energy Center/University of Central Florida nor any agency thereof, nor any of their employees, makes any warranty, express or implied, or assumes any legal liability or responsibility for the accuracy, completeness, or usefulness of any information, apparatus, product, or process disclosed, or represents that its use would not infringe privately owned rights. Reference herein to any specific commercial product, process, or service by trade name, trademark, manufacturer, or otherwise does not necessarily constitute or imply its endorsement, recommendation, or favoring by the Florida Solar Energy Center/University of Central Florida or any agency thereof. The views and opinions of authors expressed herein do not necessarily state or reflect those of the Florida Solar Energy Center/University of Central Florida or any agency thereof. 
Final Report: Cooling Seasonal Energy and Peak Demand Impacts of Improved Duct Insulation on Fixed-Capacity (SEER 13) and Variable-Capacity (SEER 22) Heat Pumps

C. Withers, J. Cummings, and B. Nigusse Building America Partnership for Improved Residential Construction 


\section{NOTICE}

This report was prepared as an account of work sponsored by an agency of the United States government. Neither the United States government nor any agency thereof, nor any of their employees, subcontractors, or affiliated partners makes any warranty, express or implied, or assumes any legal liability or responsibility for the accuracy, completeness, or usefulness of any information, apparatus, product, or process disclosed, or represents that its use would not infringe privately owned rights. Reference herein to any specific commercial product, process, or service by trade name, trademark, manufacturer, or otherwise does not necessarily constitute or imply its endorsement, recommendation, or favoring by the United States government or any agency thereof. The views and opinions of authors expressed herein do not necessarily state or reflect those of the United States government or any agency thereof.

Available electronically at SciTech Connect http:/www.osti.gov/scitech

Available for a processing fee to U.S. Department of Energy

and its contractors, in paper, from:

U.S. Department of Energy

Office of Scientific and Technical Information

P.O. Box 62

Oak Ridge, TN 37831-0062

OSTI http://www.osti.gov

Phone: 865.576.8401

Fax: 865.576.5728

Email: reports@osti.gov

Available for sale to the public, in paper, from:

U.S. Department of Commerce

National Technical Information Service

5301 Shawnee Road

Alexandria, VA 22312

NTIS http://www.ntis.gov

Phone: 800.553 .6847 or 703.605 .6000

Fax: 703.605.6900

Email: orders@ntis.gov 


\title{
Final Report: Cooling Seasonal Energy and Peak Demand Impacts of Improved Duct Insulation on Fixed-Capacity (SEER 13) and Variable-Capacity (SEER 22) Heat Pumps
}

\author{
Prepared for: \\ The National Renewable Energy Laboratory \\ On behalf of the U.S. Department of Energy's Building America Program \\ Office of Energy Efficiency and Renewable Energy \\ 15013 Denver West Parkway \\ Golden, CO 80401 \\ NREL Contract No. DE-AC36-08GO28308 \\ Prepared by: \\ C. Withers, J. Cummings, and B. Nigusse \\ Building America Partnership for Improved Residential Construction \\ and the Florida Solar Energy Center \\ 1679 Clearlake Rd \\ Cocoa, Florida, 32922
}

NREL Technical Monitor: Stacey Rothgeb

Prepared under Subcontract No. KNDJ-0-40339-02

September 2016 
The work presented in this report does not represent performance of any product relative to regulated minimum efficiency requirements.

The laboratory and/or field sites used for this work are not certified rating test facilities. The conditions and methods under which products were characterized for this work differ from standard rating conditions, as described.

Because the methods and conditions differ, the reported results are not comparable to rated product performance and should only be used to estimate performance under the measured conditions. 


\section{Contents}

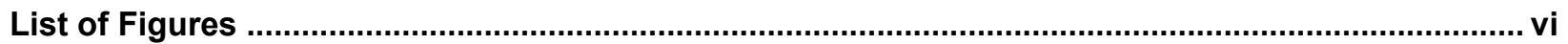

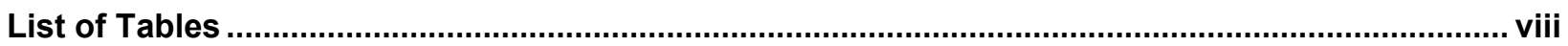

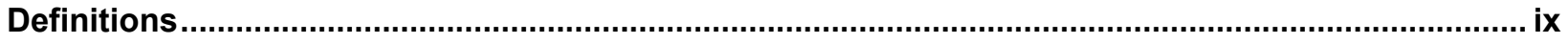

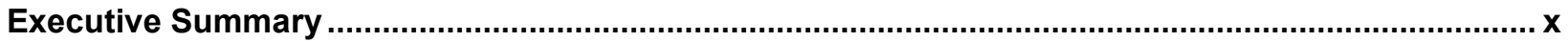

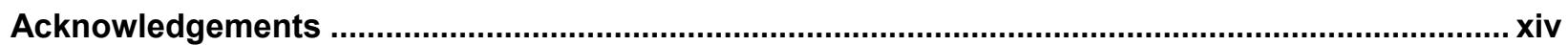

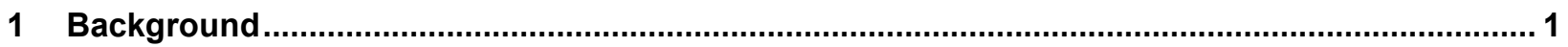

1.1 Two Operation Modes for the Variable-Capacity Heat Pump...........................................4

1.2 How the Variable-Capacity iQ Drive Heat Pump Operates ..............................................4

1.3 Extended System Run Time Causes Increased Duct Losses ...........................................5

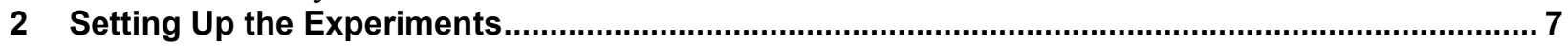

2.1 Data Acquisition and Measurement Equipment ...................................................

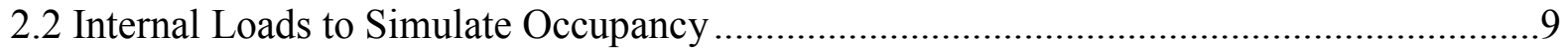

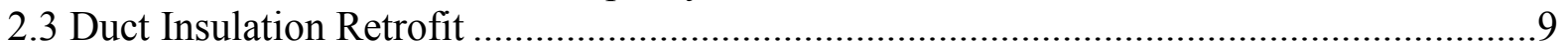

2.3.1 The Pre-retrofit Duct System ........................................................................

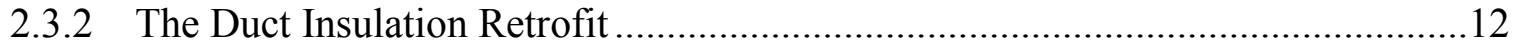

2.4 Determining Pre- and Post-retrofit Supply Duct R-Values .........................................19

2.4.1 Calculation Method to Determine Effective R-Value ........................................20

2.4.2 Calculated Effective R-values....................................................................22

2.5 Experimental Configurations ................................................................................25

3 Indoor and Outdoor Environmental Conditions and System Run Times during the Cooling

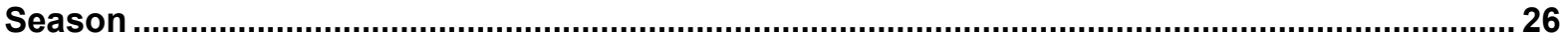

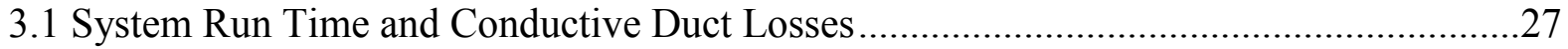

3.2 Indoor Humidity Control .......................................................................................29

4 Seasonal Cooling Energy Impacts of Duct R-value ............................................................ 32

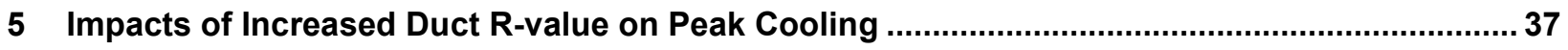

5.1 Discussion of Duct Insulation Impacts on Peak Cooling Demand .................................38

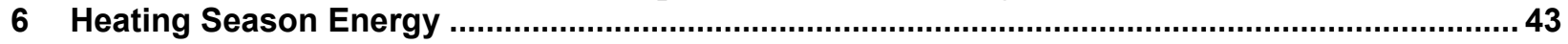

6.1 Discussion of Heating System Performance/Data Problems .........................................44

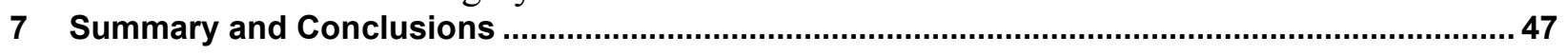

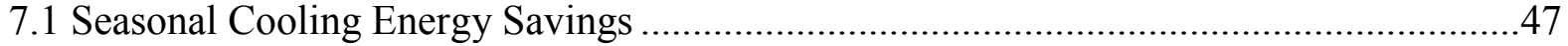

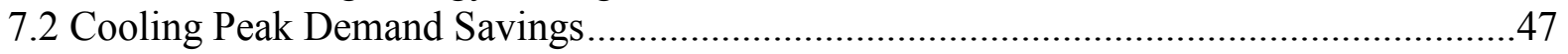

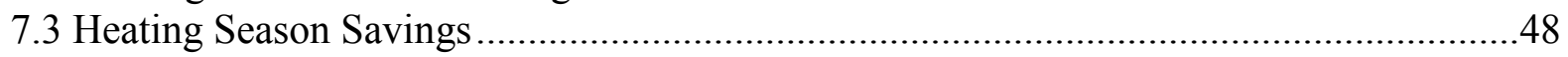

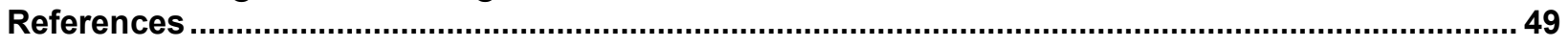

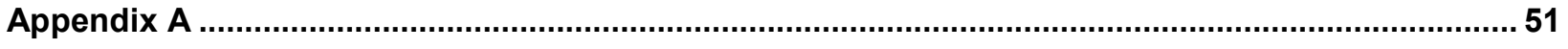

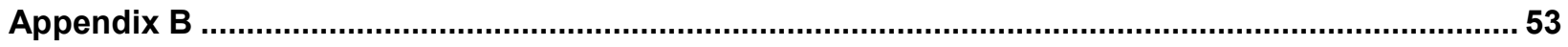




\section{List of Figures}

Figure 1. Measured coefficient of performance (COP) versus capacity fraction for the Nordyne 2ton variable-capacity heat pump. The best-fit line for the $78-83^{\circ} \mathrm{F}$ temperature bin is marked at $63 \%$ average capacity factor, which was typical for its operation in the MH Lab house.

Figure 2. Measured COP versus capacity fraction for a Nordyne 3-ton variable-capacity heat pump; the best-fit line for the $78-83^{\circ} \mathrm{F}$ temperature bin is marked at $42 \%$, which is average capacity factor for the 3-ton system's operation in the MH Lab house.

Figure 3. Layout of the attic ductwork in the MH Lab, showing two supply plenums (P), five supply junction boxes (A through E), flex ducts, which vary in size from 5 to 12 inches in diameter, and 10 supply terminal register drops (1 through 10$)$

Figure 4. Flex duct section 8A partially covered by attic insulation prior to being wrapped with insulation.

Figure 5. Duct section PA located about three feet downstream of supply plenum prior to insulation.

Figure 6. Duct section PA after insulation wrap has been installed. In the red rectangle, the foil facing will be tucked under and cellulose added. In the red circle, the foil facing has been tucked under, and a small amount of cellulose insulation has been added where the duct wrap meets the existing cellulose.

Figure 7. A supply plenum box after insulation wrap was applied. Insulation seams were sealed with reinforced metal tape applied with a squeegee.

Figure 8. Attic and ambient dry-bulb temperatures with $T_{\text {ambient,avg }}=81.6^{\circ} \mathrm{F}, \mathrm{T}_{\text {attic,avg }}=90.5^{\circ} \mathrm{F}$, and near full sunshine, shown as daily composite plot for July 27-August 1, 2013

Figure 9. Composite attic dry-bulb (red) and dew point (blue) temperatures ( ${ }^{\circ} \mathrm{F}$ ) for July 27August 1, 2013 at the MH Lab.

Figure 10. Moisture readings at two duct locations for the period August 30-November 2, $2013 . .17$

Figure 11. Moisture content of the air within cellulose insulation taken from under duct sections PA (samples 1 and 2) and 10A (samples 3 and 4)

Figure 12. Attic, indoor, and supply air temperatures occurring during duct system R-value testing for pre- and post-retrofit periods

Figure 13. Cooling energy use as a function of delta-T (outdoor minus indoor temperature) for the 2-ton SEER 13 and SEER 22 heat pumps before and after duct insulation enhancement ......... 33

Figure 14. Cooling energy use as a function of delta-T for the 2-ton SEER 13 heat pump before and after duct insulation enhancement.

Figure 15. Cooling energy use as a function of delta-T for the 2-ton SEER 22 heat pump in standard control mode (RH control not activated) before and after duct insulation enhancement.

Figure 16. Cooling energy use as a function of delta-T for the 2-ton SEER 22 heat pump with RH control activated at $45 \%$ before and after duct insulation enhancement

Figure 17. Least-squares regression analysis for 2 to 7 PM hourly data from hot summer days for pre- and post-duct insulation upgrade for the SEER 13 system 
Figure 18. Least-squares regression analysis for 2 to 7 PM hourly data from hot summer days for pre- and post-duct insulation upgrade for the SEER 22 system in standard control mode....... 38

Figure 19. Least-squares regression analysis for 2 to 7 PM hourly data from hot summer days for pre- and post-duct insulation upgrade for the SEER 22 system with $45 \%$ RH control activated 38

Figure 20. Least-squares regression analysis for 2 to 7 PM hourly data from hot summer days for pre-duct insulation upgrade for the SEER 13 system. Yellow line is for data at $100 \%$ run time.40

Figure 21. Outdoor and indoor temperatures with 2-ton SEER 13 system run time shown at hourly intervals before duct insulation wrap was added

Figure 22. Outdoor and indoor temperatures with 2-ton SEER 13 system run time shown at hourly intervals after duct insulation wrap was added

Figure 23. Daily heating energy use as a function of delta-T for the SEER 13 and SEER 22 heat pumps

Figure 24. Heating EER for the SEER 22 two-ton heat pump for the pre- and post-retrofit periods. Data points represent 15 -minute periods with $100 \%$ AHU run time. Points falling far above the best-fit lines represent periods when system capacity was ramping down while points falling far below the best-fit lines represented either periods when system capacity was ramping up or when a defrost cycle was occurring.

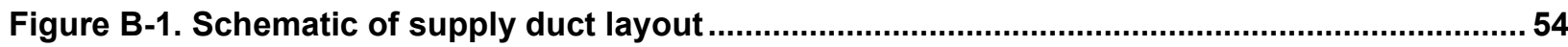

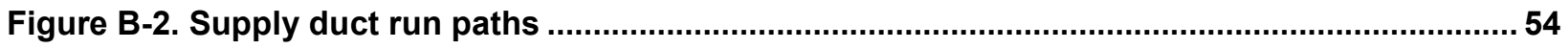

Figure B-3. Buried and unburied ducts thermal network representation ......................................... 56

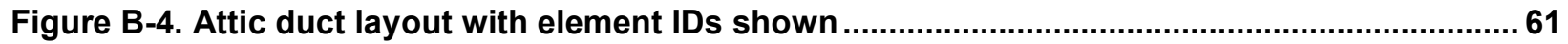

Figure B-5. Resulting calculated effective duct surface to surface R-Values before and after adding insulation wrap to attic ducts

Unless otherwise noted, all figures were created by BA-PIRC. 


\section{List of Tables}

Table ES-1. Energy Consumption for 2-Ton Heat Pumps for Attic Ducts Base Level R-6, and with Enhanced Duct Insulation R-11 as well as with Indoor Duct System. Results Based on Regression Analysis at $77^{\circ} \mathrm{F}$ Indoor and $82^{\circ} \mathrm{F}$ Outdoor Conditions.

Table ES-2. Peak Demand Best-Fit Equation and Coefficients in the Form of $Y=A+B(X)$, for Preand Post-duct Wrap for Three System Configurations, Where $Y$ is the Peak Hour Cooling Electrical Energy Use and $X$ is Delta-T $\left(X=15^{\circ} \mathrm{F}\right.$ for This Example; $92^{\circ} \mathrm{F}$ Outdoors and $77^{\circ} \mathrm{F}$ Indoors) xii

Table 1. Nordyne Variable-Capacity (iQ Drive) Heat Pumps Rated Cooling Performance (Nordyne Elite Training 2009)

Table 2. Lab Testing and Monitoring Equipment Used in the Phase 1 and Phase 3 Experiments..... 8

Table 3. Various Components of the Attic Duct System (from Figure 3) are Labeled. Flex Duct Sections are Identified by Grill Number and Junction Box. Plenum and Supply Junction Boxes are Identified by a Single Letter.

Table 4. Average Outdoor and Indoor Temperature, Indoor RH, and Cooling System Run Time for all Days When Cooling Occurred Including Days When Outdoor Dew Point Temperature was Below $70^{\circ} \mathrm{F}$ Using 2-Ton Heat Pumps.

Table 5. Average Outdoor and Indoor Temperature, Indoor RH, and Cooling System Run Time for All Days When Cooling Occurred and Outdoor Dew Point Temperature was $70^{\circ} \mathrm{F}$ or Higher, Using 2-Ton Heat Pumps.

Table 6. Energy Consumption for 2-Ton Heat Pumps for Attic Ducts Base Level R-6, and with Enhanced Duct Insulation R-11 as well as with Indoor Duct System. Results Based on Regression Analysis at $77^{\circ} \mathrm{F}$ Indoor and $82^{\circ} \mathrm{F}$ Outdoor Conditions.

Table 7. Average Outdoor and Indoor Temperature, Indoor RH, and Cooling System Run Time for Days When Outdoor Dew Point Temperature was $70^{\circ} \mathrm{F}$ or Higher during May 1, 2010, through October 28, 2010, for Phase 1 Using 3-Ton Heat Pumps. The Data Has Been Screened So That the Phase 1 and Phase 3 Data Sets Have Comparable Outdoor Temperatures.

Table 8. Regression Analysis Results and Energy Consumption for 2-Ton Heat Pumps (SEER 13 and SEER 22 Units) with "As Found" (R-6.1) and with Enhanced (R-11.6) Duct Insulation (with and without RH Control Activated for the iQ Drive System) for $5^{\circ} \mathrm{F}$ Delta-T, Which Represents a Typical Summer Day $\left(77^{\circ}\right.$ Indoors and $82^{\circ}$ Outdoors)

Table 9. Peak Demand Best-Fit Equation and Coefficients in the Form of $Y=A+B(X)$, for Pre- and Post-duct Wrap for Three System Configurations, Where $Y$ is the Peak Hour Cooling Electrical Energy Use and $X$ is Delta-T $\left(X=15^{\circ} \mathrm{F}\right.$ for This Example; $92^{\circ} \mathrm{F}$ Outdoors and $77^{\circ}$ Indoors) ...... 39

Table B-1. The Input Elements Used in Calculating the Effective R-value of the Lab Duct System Before and After Adding Insulation to Attic Ducts

Unless otherwise noted, all tables were created by BA-PIRC. 


\section{Definitions}

$\mathrm{AC}$

AHU

ASHRAE

Balance air

COP

DX

ECM

EER

FSEC

HSPF

LMTD

MH Lab

Nmax

$\mathrm{Q}_{25, \text { out }}$

$r^{2}$

RH

RL

SEER

SEER 13; S13

SEER 22; S22

SEER 22 (45\%)

SHR

SL

$\mathrm{T}_{\text {ambient }}$

$\mathrm{T}_{\mathrm{ambient}, \mathrm{dp}}$
Air conditioning

Air handling unit

American Society of Heating, Refrigerating and Air-Conditioning Engineers

Air drawn into a house when mechanical systems create negative pressure in the house (e.g., an exhaust fan depressurizes the house and balance air is drawn in to replace the exhausted air stream).

Coefficient of performance- - heating or cooling energy produced divided by the electrical energy input

Direct-expansion

Electronically-commutated motor

Energy efficiency ratio-Btus of cooling produced per Wh of electrical energy consumed at specific test conditions

Florida Solar Energy Center

Heating seasonal performance factor

Log mean temperature difference

Manufactured Housing Laboratory (on FSEC campus)

The cycling rate of a space conditioning system, affected by thermostat characteristics, and expressed in number of cycles per hour (or other units of time) when the space conditioning system is operating at $50 \%$ load factor

Duct airtightness expressed as air leakage ( $\mathrm{cfm})$ from the duct system to locations outside the air boundary of the conditioned space

Coefficient of determination

Relative humidity

Return leakage

Seasonal energy efficiency ratio

Fixed-capacity heat pump with cooling efficiency rating of SEER 13

Variable-capacity heat pump with cooling efficiency rating of SEER 22

SEER 22 heat pump when operated with RH control set to $45 \%$

Sensible Heat Ratio; fraction of cooling energy applied to lowering the dry-bulb temperature of the room air

Supply leakage

Ambient air temperature; this is dry-bulb temperature

Ambient dew point temperature 


\section{Executive Summary}

A new generation of full variable-capacity, central, ducted air-conditioning (AC) and heat pump units has come on the market, and they promise to deliver increased cooling (and heating) efficiency. They are controlled differently than standard single-capacity (fixed-capacity) systems. Instead of cycling on at full capacity and then cycling off when the thermostat is satisfied, they can vary their capacity over a wide range (approximately $40 \%$ to $118 \%$ of nominal full capacity), thus staying "on" for up to twice as many hours per day compared to fixedcapacity systems of the same nominal capacity. The heating and cooling capacity is varied by adjusting the indoor fan air flow rate, compressor, and refrigerant flow rate as well as the outdoor unit fan air flow rate. Note that two-stage AC or heat pump systems were not evaluated in this research effort. The term $d$ well is used to refer to the amount of time distributed air spends inside ductwork during space-conditioning cycles. Longer run times mean greater dwell time and therefore greater exposure to conductive gains and losses.

Two factors impact the efficiency of variable-capacity systems relative to fixed-capacity systems. First, variable-capacity systems operate at higher efficiencies at their lower capacity ranges; thus, under low load the variable-capacity systems operate at high efficiency, whereas the fixed-capacity systems cycle on and off, incurring so-called cycling losses. Previous testing has shown that a specific manufacturer-oversized (3-ton) variable-capacity system yielded more energy savings compared to "right-sized" (2-ton) system in controlled house lab testing. Second, conditioned air dwells in the ductwork (often located in the attic) $60 \%$ to $100 \%$ longer in variable-capacity systems relative to fixed-capacity systems. This causes some additional conductive losses for variable-capacity systems compared to fixed-capacity systems when ducts are located outside of the conditioned space. Much of the work in this report was to better understand the magnitude of this effect.

Previous phase 1,2, and 3 research identified that duct conductive losses to an attic environment imposed greater relative energy losses for the variable-capacity systems compared to the fixedcapacity systems (Cummings and Withers 2011) because of the longer dwell time of conditioned air in the ducts. The earlier experiments isolated the "dwell air" effect by comparing the performance of the variable and fixed-capacity systems with ducts located in the attic and ducts located inside the living space. The purpose of the Phase 4 experiments reported here was to see if duct R-value enhancement would benefit the overall operating efficiency of the variablecapacity system relatively more than the fixed-capacity system.

The current Phase 4 experiments (the primary focus of this report) found that this was a secondary effect. In Phase 4, the R-value of the attic duct system was increased from 6.1 to 11.6 by applying a foil-faced insulation product. The relative energy performance of the fixedcapacity and variable-capacity systems was examined with this higher efficiency attic duct system. Regression analysis was used to determine daily cooling energy use as a function of temperature differential between outdoors and indoors. Table ES-1 shows that at a daily average delta- $\mathrm{T}$ of $5^{\circ} \mathrm{F}\left(82^{\circ} \mathrm{F}\right.$ outdoors and $77^{\circ} \mathrm{F}$ indoors $)$, cooling energy savings from the duct insulation upgrade was $6.4 \%$ for the fixed-capacity SEER 13 system, $6.9 \%$ for the variable-capacity SEER 22 system (in standard control mode), and $8.2 \%$ for the variable-capacity SEER 22 system in relative humidity $(\mathrm{RH})$ control mode set to $45 \% \mathrm{RH}$ (RH45). These percentages are relative to the higher and lower energy use of the fixed- and variable-capacity systems, respectively. This is 
a way of isolating the dwell air effect, but it does not give a sense of the absolute magnitude and importance of the effect.

Table ES-1. Energy Consumption for 2-Ton Heat Pumps for Attic Ducts Base Level R-6 and with Enhanced Duct Insulation R-11 as well as with Indoor Duct System. Results Are Based on Regression Analysis at $77^{\circ} \mathrm{F}$ Indoor and $82^{\circ} \mathrm{F}$ Outdoor Conditions.

\begin{tabular}{|c|c|c|c|c|c|c|c|c|}
\hline $\begin{array}{l}\text { Heat Pump } \\
\text { System }\end{array}$ & $\begin{array}{c}\text { Duct } \\
\text { R-value }\end{array}$ & $\begin{array}{c}\text { Energy } \\
(\mathrm{kWh} / \mathrm{d})\end{array}$ & $\begin{array}{c}\text { Saved } \\
\text { kwh/d R6 } \\
\text { to R11 } \\
\text { attic }\end{array}$ & $\begin{array}{c}\text { \% Energy } \\
\text { Savings R6 } \\
\text { to R11 } \\
\text { Attic }\end{array}$ & $\begin{array}{c}\text { Saved } \\
\text { kwh/d R6 } \\
\text { Attic to } \\
\text { Indoor }\end{array}$ & $\begin{array}{c}\text { \% Energy } \\
\text { Savings R6 } \\
\text { Attic to } \\
\text { Indoor }\end{array}$ & \begin{tabular}{|c} 
Saved \\
kwh/d \\
R11 Attic \\
to Indoor
\end{tabular} & $\begin{array}{l}\text { \% Energy } \\
\text { Savings } \\
\text { R11 Attic } \\
\text { to Indoor }\end{array}$ \\
\hline SEER 13 attic & 6 & 23.83 & & & & & & \\
\hline SEER 13 attic & 11 & 22.30 & 1.54 & $6.4 \%$ & & & & \\
\hline $\begin{array}{l}\text { SEER } 13 \\
\text { indoor }\end{array}$ & 6 & 20.89 & & & 2.94 & $12.3 \%$ & 1.41 & $6.3 \%$ \\
\hline SEER 22 attic & 6 & 16.57 & & & & & & \\
\hline SEER 22 attic & 11 & 15.42 & 1.15 & $6.9 \%$ & & & & \\
\hline $\begin{array}{l}\text { SEER } 22 \\
\text { indoor }\end{array}$ & 6 & $\mathrm{~N} / \mathrm{A}$ & & & & & & \\
\hline $\begin{array}{c}\text { SEER } 22 \\
\text { (RH45) attic }\end{array}$ & 6 & 19.71 & & & & & & \\
\hline $\begin{array}{c}\text { SEER } 22 \\
\text { (RH45) attic }\end{array}$ & 11 & 18.10 & 1.61 & $8.2 \%$ & & & & \\
\hline $\begin{array}{l}\text { SEER } 22 \\
\text { (RH45) } \\
\text { indoor }\end{array}$ & 6 & 16.2 & & & 3.51 & $17.8 \%$ & 1.90 & $10.5 \%$ \\
\hline
\end{tabular}

Observing the (kwh/day) columns in Table ES-1 and normalizing the percentage calculations to the cooling energy used by the SEER 13 fixed-capacity unit with R6 ducts in the attic (the base case), we see that the absolute effect of dwell air for fixed- versus variable-capacity equipment ranges from about $2.4 \%$ to $-1.6 \%(0.57$ to $-0.39 \mathrm{kWh} /$ day $)$. Assuming a cost of electricity of $\$ 0.15 / \mathrm{kwh}$ and an 8-month, 24-hour/day cooling season, the difference in "dwell air" effect between the variable- and fixed-capacity systems amounts to roughly $\$ 20 /$ year.

Peak cooling demand savings from the duct insulation upgrade was also examined. Regression analysis found peak demand reductions of $56 \mathrm{~W}, 285 \mathrm{~W}$, and $206 \mathrm{~W}$ for the SEER 13, SEER 22, and SEER 22 (45\%) system configurations, respectively, for 15 degrees delta- $\mathrm{T}\left(\mathrm{T}_{\mathrm{ambient}}-\right.$ $\left.\mathrm{T}_{\text {indoors }}\right)$. On average, peak demand reduction was $182 \mathrm{~W}$ for the three test configurations. 
Table ES-2. Peak Demand Best-Fit Equation and Coefficients in the Form of $Y=A+B(X)$, for Preand Post-duct Wrap for Three System Configurations Where $Y$ Is the Peak Hour Cooling Electrical Energy Use and $X$ is Delta-T ( $X=15^{\circ} \mathrm{F}$ for This Example; $92^{\circ} \mathrm{F}$ Outdoors and $77^{\circ} \mathrm{F}$ Indoors)

\begin{tabular}{|c|c|c|c|c|c|c|}
\hline & $\begin{array}{c}\text { SEER } \\
13 \\
\text { Pre- }\end{array}$ & $\begin{array}{l}\text { SEER } \\
13 \\
\text { Post- }\end{array}$ & $\begin{array}{c}\text { SEER } \\
22 \\
\text { Pre- }\end{array}$ & $\begin{array}{c}\text { SEER } \\
22 \\
\text { Post- }\end{array}$ & $\begin{array}{c}\text { SEER } 22 \\
\text { (RH45) } \\
\text { Pre- }\end{array}$ & $\begin{array}{c}\text { SEER } \\
22 \\
\text { (RH45) } \\
\text { Post- }\end{array}$ \\
\hline (A) kW & 0.4898 & 0.5774 & 0.5308 & 0.2875 & 0.5854 & 0.5308 \\
\hline (B) $k W-{ }^{\circ} F$ & 0.0954 & 0.0858 & 0.0891 & 0.0863 & 0.0787 & 0.0686 \\
\hline 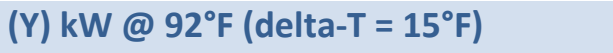 & 1.9208 & 1.8644 & 1.8673 & 1.5820 & 1.7659 & 1.5598 \\
\hline Savings post- versus pre-retrofit (kW) & & 0.0564 & & 0.2853 & & 0.2061 \\
\hline Savings post- versus pre-retrofit (\%) & & $2.9 \%$ & & $15.3 \%$ & & $11.7 \%$ \\
\hline
\end{tabular}

Observing the fourth row in Table ES-2, and normalizing the percentage savings calculations to the SEER 13 base case energy usage at $92^{\circ} \mathrm{F}$, the absolute effect of dwell air for the variablecapacity unit relative to the fixed-capacity unit ranges from $11.9 \%$ to $7.8 \%$ ((S22savings$0.0564) / 1.9208)$. This indicates more importance for the dwell air effect at peak operating conditions than for the seasonal analysis; however, this result is uncertain. The uncertainty is because in the pre-retrofit phase there were some periods when the fixed-capacity unit could not meet the peak load. This impact would tend to make the savings from adding duct insulation to the fixed-capacity system look smaller and the dwell air effect for the variable-capacity system look relatively larger.

The most important conclusions from this study are:

- The biggest savings come from using SEER 22 variable-capacity equipment instead of SEER 13 fixed-capacity equipment ( $20 \%$ to $30 \%$ of the base case cooling energy consumption).

- The next biggest savings regardless of the SEER rating or dwell air issue comes from adding additional insulation to the ducts or, even better, moving the ducts inside the conditioned space (12\% to $15 \%$ of the base case cooling energy consumption).

- The dwell air issue appears to be a second-order effect.

- The "right-sizing" of variable-capacity equipment is quite different than that for fixedcapacity equipment. Some oversizing is beneficial; however, the oversizing must be limited such that cycling losses under low loads are not large enough to negate efficiency gains from longer run times just above the minimum capacity point of the equipment. It is critical that the lowest available capacity of a variable-capacity unit does not exceed the peak design cooling and heating load.

Some counterintuitive results in this study would need further investigation to confirm or reject. These include: 
- The finding that fixed-capacity equipment controlled humidity better in the living space than did variable-speed equipment.

- The finding that larger sized equipment (3 ton instead of 2 ton) controlled humidity in the living space better for both the SEER 13 and SEER 22 units.

The study was originally intended to include heating as well as cooling. Some heating season data was collected; however, late-developing failures of the SEER 22 variable-capacity system combined with a very mild heating season prevented sufficient meaningful heating season data from being collected. 


\section{Acknowledgements}

The authors would like to express thanks to Florida Solar Energy Center (FSEC) staff: David Hoak for the high level of technical support and daily maintenance of the lab facility, internal load systems, data acquisition system, heat pump systems, and day-to-day management of the Manufactured Housing Laboratory (MH Lab) and the SEER 21 experiments, all of which were critical to successful experimental outcomes, and Eric Martin for his continued support and encouragement in this work. 


\section{Background}

Various manufacturers have introduced new lines of variable-capacity, central ducted airconditioning (AC) and heat pump systems. Nordyne offers the "iQ Drive" system, which is marketed through a number of brand names. The Nordyne product was selected for this study because it was the first available variable-capacity, central ducted system product line, and was available for purchase at the start of earlier phases of this project. The Nordyne iQ Drive systems have achieved very high efficiency ratings. The straight cool units have energy-efficiency ratings in the range of seasonal energy efficiency ratio (SEER) 22 to 24.5. The heat pump units have efficiency ratings in the range of SEER 21 to 22. Carrier and Lennox have also introduced variable-capacity, central ducted heat pumps. The Carrier units have capacity ranging from $40 \%$ to $100 \%$ of nominal. The Lennox units have capacity ranging from $35 \%$ to $100 \%$ of nominal. For these experiments, a 2-ton Nordyne variable-capacity SEER 22 unit has been tested in a side-byside configuration with a 2-ton fixed-capacity SEER 13 unit. SEER 13 is currently the lowest efficiency central ducted residential cooling system that is permitted in new installations, thus we can compare an ultra-efficient system to the lowest available efficiency system.

The 2-ton iQ Drive heat pump used in these experiments has nominal 23,000 Btu/h cooling capacity and 22,600 Btu/h nominal heating capacity. At lowest cooling capacity, the 2-ton unit produces a rated $11,300 \mathrm{Btu} / \mathrm{h}$ (0.94 tons) of cooling. At highest cooling capacity, this unit produces $26,900 \mathrm{Btu} / \mathrm{h}$ (2.24 tons) of cooling. The cooling capacity of this heat pump then varies by a factor of 2.4 , from $42 \%$ to $100 \%$ of maximum capacity (Table 1 ).

Table 1. Nordyne Variable-Capacity (iQ Drive) Heat Pumps Rated Cooling Performance (Nordyne Elite Training 2009)

\begin{tabular}{|c|c|c|c|c|c|c|}
\hline $\begin{array}{l}\text { Outdoor Unit } \\
\text { Model Number } \\
\text { FT4BI }\end{array}$ & Indoor Unit & $\begin{array}{l}\text { Range } \\
\text { Cooling } \\
\text { Capacity } \\
\text { @ } 95^{\circ} \text { OD } \\
\text { Btu/h }\end{array}$ & $\begin{array}{l}\text { EER@ } \\
\text { Nomina } \\
1 \\
\text { Capacit } \\
\text { y }\end{array}$ & SEER & $\begin{array}{l}\text { Nominal } \\
\text { Capacity } \\
\text { Btu/h }\end{array}$ & $\begin{array}{l}\text { Air Flow } \\
\text { Range } \\
\text { SCFM }\end{array}$ \\
\hline $024 \mathrm{~K}$ & $\begin{array}{l}\text { B4VM-E24K- } \\
\text { B }\end{array}$ & $11,300-26,900$ & 14.6 & 22 & 23,000 & $500-950$ \\
\hline $036 \mathrm{~K}$ & $\begin{array}{l}\text { B4VM-E36K- } \\
\text { B }\end{array}$ & $14,200-40,700$ & 13.0 & 21 & 35,000 & $680-1110$ \\
\hline $048 \mathrm{~K}$ & $\begin{array}{l}\text { B4VM-E48K- } \\
\text { C }\end{array}$ & $14,300-48,000$ & 12.5 & 21 & 44,500 & $725-1800$ \\
\hline
\end{tabular}

Note: Energy efficiency ratio, EER

Unlike traditional cooling systems, which cycle on and off either on at full capacity or off, the iQ Drive system modulates capacity across a wide range. For the 2-ton system, the rated range is $49 \%$ to $117 \%$ of nominal (Table 1). For the larger 3-ton system (tested in earlier experiments), 
the rated range is $41 \%$ to $116 \%$ of nominal. The authors use the term rated range because in actual operation, the capacity range is smaller than this. The cooling capacities that define the rated range are determined by the manufacturer at outdoor conditions of $95^{\circ} \mathrm{F}$ with return air of $80^{\circ} \mathrm{F} \mathrm{db} / 67^{\circ} \mathrm{F} \mathrm{wb}$. In actual everyday operation, however, lowest capacity typically occurs when ambient conditions are lower than $95^{\circ} \mathrm{F}$ (more commonly about $82^{\circ} \mathrm{F}$ ), so capacity will be considerably higher than the rated values during normal operation.

Capacity is modulated based on the degree of deviation of room temperature from set point. In cooling mode, the "steps" of cooling range from one to eleven over a thermostat range from two degrees below set point to three degrees above set point. Heating capacity is controlled over a six-degree band from three degrees above set point to three degrees below set point.

The iQ Drive heat pump achieves very high energy efficiency when operating at a small fraction of its total capacity because the evaporator and condenser coils are considerably oversized, allowing for efficient heat exchange. An additional factor improves efficiency - the compressor operates more efficiently when operating at lower speeds (as low as $15 \mathrm{~Hz}$ ). As a result of these two effects, cooling energy efficiency is about $43 \%$ higher when operating at minimum capacity compared to full nominal capacity $(85 \%$ of maximum capacity $=$ full nominal capacity) for ambient temperature in the range of $78-83^{\circ} \mathrm{F}$ (Figure 1). Cooling energy efficiency is about $64 \%$ higher when operating at minimum capacity compared to maximum capacity for ambient temperature in the range of $78-83^{\circ} \mathrm{F}$ (return air was typically at $\sim 74^{\circ} \mathrm{F} / 55 \%$ relative humidity (RH) throughout the experiments).

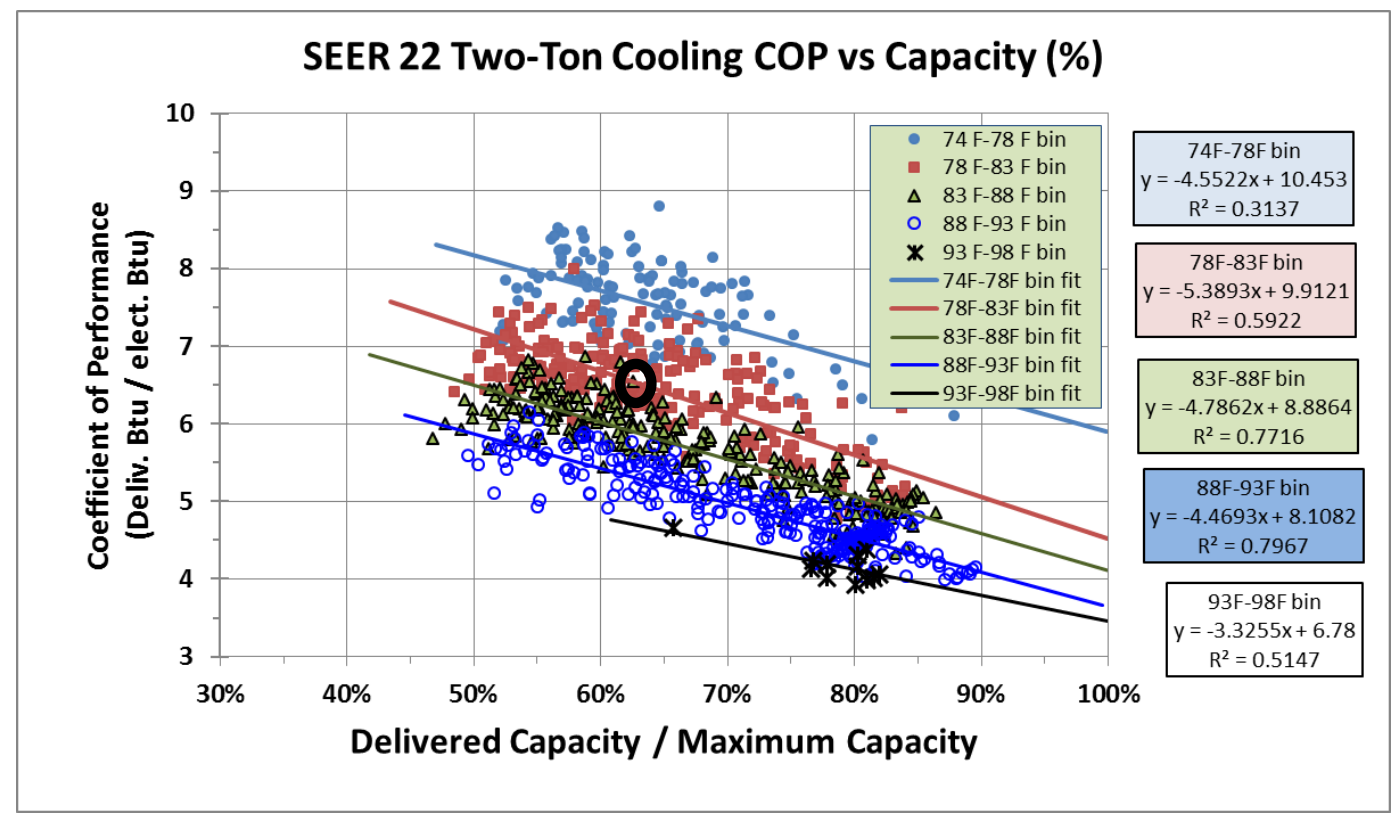

Figure 1. Measured coefficient of performance (COP) versus capacity fraction for the Nordyne 2ton variable-capacity heat pump. The best-fit line for the $78-83^{\circ} \mathrm{F}$ temperature bin is marked at $63 \%$ average capacity factor, which was typical for its operation in the MH Lab house.

This pattern of higher efficiency at lower capacity fraction is true for each of the five outdoor temperature bins of Figure 1. Note that these performance data points do not reflect efficiency losses associated with cycling or conductive duct losses because they represent $100 \%$ run time periods, and delivered capacity is measured from entry to exit of the air handling unit (AHU). 
Similar patterns of cooling energy efficiency occur for the larger 3-ton iQ Drive heat pump used in earlier Manufactured Housing Laboratory (MH Lab) experiments (Figure 2).

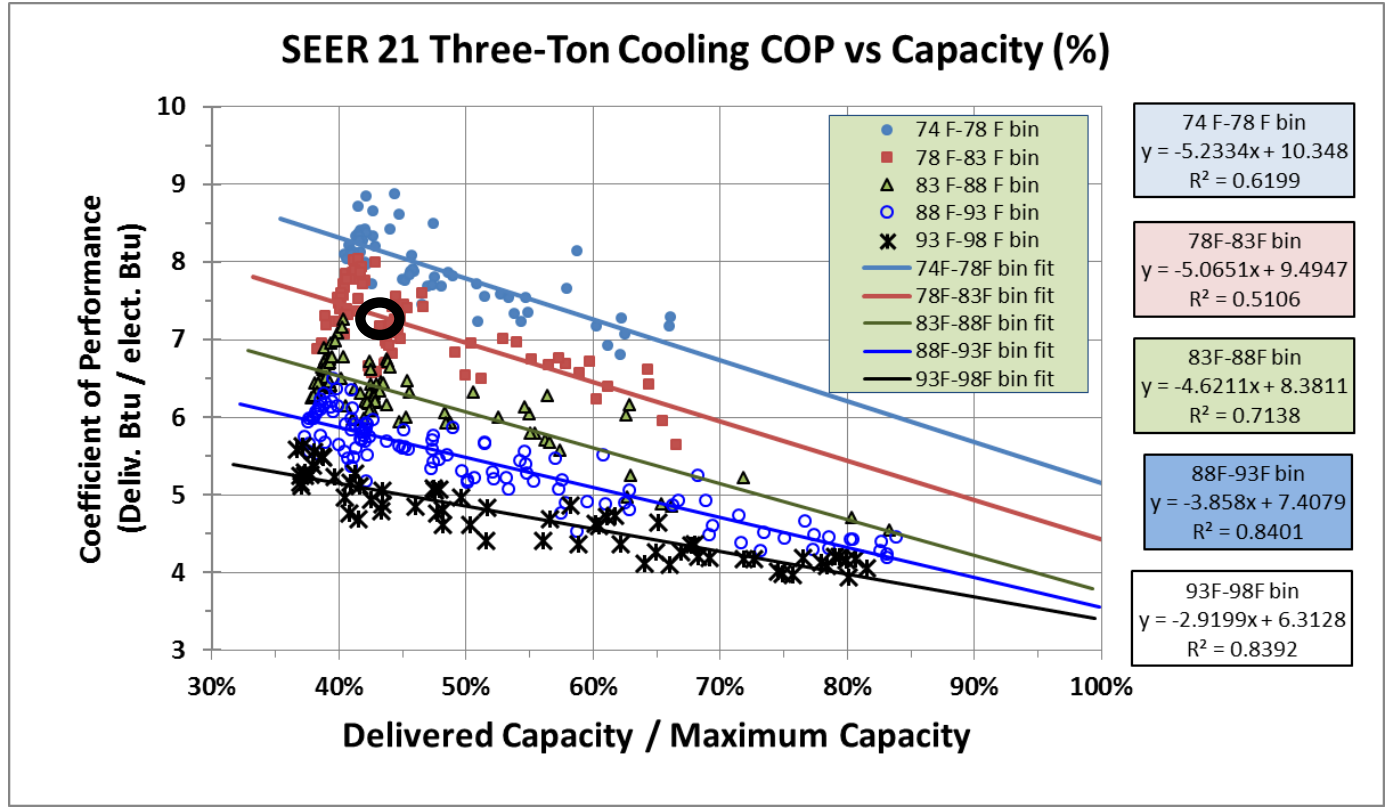

Figure 2. Measured COP versus capacity fraction for a Nordyne 3-ton variable-capacity heat pump; the best-fit line for the $78-83^{\circ} \mathrm{F}$ temperature bin is marked at $42 \%$, which is average capacity factor for the 3-ton system's operation in the MH Lab house.

The design cooling load of the MH Lab is about 23,000 Btu/h when using the attic duct system. When using the attic ductwork, the 2-ton variable-capacity system is then oversized by about $10 \%$, which means that it can be considered "right-sized". The correct heating or cooling capacity, sometimes referred to as "right-sizing", is determined by a Manual J calculation established by the Air Conditioning Contractors of America (ACCA), which currently permits equipment to be oversized up to 15 percent greater than the heating/cooling load calculation. The experiments presented in this report were performed using the ductwork located in the MH Lab attic.

Throughout most of the day, the heat pump does not turn off, but shifts to a lower capacity. This high efficiency heat pump technology achieves high SEER values by fundamentally altering the equipment design and the way the equipment operates, and these changes lead to long run times that have potential impacts on duct system conductive losses. Extended system run time was observed for an oversized (3-ton) variable-capacity system in earlier experiments and also for the 2 -ton system used in the current experiments. System operation times are generally $70-100 \%$ longer for the variable-capacity system compared to the comparably-sized, fixed-capacity systems.

- While the fixed-capacity SEER 13 2-ton unit operated about 50-55\% of the time on a typical Florida summer day, the 2-ton variable-capacity SEER 22 unit operated about $88 \%$ of the time on similar days (this percent will, of course, vary depending on the loadto-capacity ratio for any given individual home). For the 2-ton systems, then, run time is 
therefore about $70 \%$ longer for the variable-capacity system versus the fixed-capacity system.

- While the fixed-capacity SEER 13 3-ton unit operated about 36\% of the time on typical Florida summer days, the 3-ton variable-capacity SEER 21 unit operated about $70 \%$ of the time on similar days. For the 3-ton systems, then, run time is therefore about $94 \%$ longer for the variable-capacity system versus the fixed-capacity system.

As a consequence of the extended system run times, the variable-capacity system causes cold air to remain in the ductwork a large majority of the time. Therefore, conductive heat gains/losses would be expected to be greater than with a traditional fixed-capacity system. In fact, earlier research with the 3-ton heat pumps found that operation with attic ducts (in an attic with typical asphalt shingle roof) caused a 13\% increase in cooling energy use for the SEER 13 system and a $20 \%$ increase in cooling energy use for the SEER 21 system, in each case compared to indoor ducts, confirming that expectation.

\subsection{Two Operation Modes for the Variable-Capacity Heat Pump}

The iQ Drive system has two operation modes, standard control and humidity control. In standard control mode, the average air flow rate of the AHU is relatively high when the compressor is operating at low capacity (manufacturer rating of $530 \mathrm{cfm} / \mathrm{ton}$; Table 1). This elevated air flow rate would suggest, in itself, an outcome of elevated indoor RH. A competing influence, however, is the small number of on/off cycles per day. On balance, operation of the Nordyne 2-ton variable-capacity system in standard control mode produced $53.1 \%$ average indoor $\mathrm{RH}$ for all days with $\mathrm{T}_{\mathrm{ambient}, \mathrm{dp}}>70^{\circ} \mathrm{F}$. When operated in the alternative $\mathrm{RH}$ control mode, indoor RH averaged $50.7 \%$.

\subsection{How the Variable-Capacity iQ Drive Heat Pump Operates}

The Nordyne 2-ton variable-capacity system allows three elements of the cooling system to vary: AHU fan speed, compressor speed, and condenser fan speed. AHU and compressor speed varies from 15 to $60 \mathrm{~Hz}$. On an average summer day, the typical air flow range of the 2-ton iQ Drive (SEER 22) AHU is 570 to $950 \mathrm{cfm}$ in standard control mode and 170 to $880 \mathrm{cfm}$ in RH control mode. The condenser fan speed also varies, but it is not clear how it is controlled. The thermostat provides proportional capacity control that calls for specific steps of heating or cooling proportional to the difference between the room temperature and the set point. There are a total of 11 steps of cooling, but steps 10 and 11 only occur when the room temperature is 3 degrees or more above set point (Nordyne Elite Training 2009). Cooling operation occurs mostly between steps $1-8$, where step 8 is $100 \%$ of nominal rated capacity.

As discussed earlier, the Nordyne variable-capacity heat pump has two cooling modes: standard control (no RH control set point) and RH control (user selectable RH set point). In standard mode, compressor capacity declines in response to reduction in cooling load. This decline in cooling load is detected based on room air temperature deviation from set point. As room temperature falls below the set point (in cooling mode), the unit does not (at first) turn off, but rather the compressor slows until it reaches lowest capacity ( $\sim 50 \%$ of nominal). The AHU fan speed declines as well, but does not fall below about $570 \mathrm{cfm}$ for the 2-ton (about $60 \%$ of full flow) when operating at minimum capacity. Because the AHU fan uses an electronicallycommutated motor (ECM), the energy consumption of the fan is much lower than a standard shaded-pole motor, particularly when operating at fractional speed. 
In humidity control mode, compressor capacity declines in response to reduction in cooling load, but AHU fan speed declines proportionally even more. While AHU air flow (at minimum capacity) for the 2-ton system is on the order of $570 \mathrm{cfm}$ in standard mode (about $628 \mathrm{cfm} / \mathrm{ton}$ ), it declines to as low as $150 \mathrm{cfm}$ in RH control mode (about $160 \mathrm{cfm} / \mathrm{ton}$ ). The transition to low air flow in the RH control mode (with cooling capacity at minimum, which can vary from 11,300 $\mathrm{Btu} / \mathrm{h}$ at $95^{\circ} \mathrm{F}$ to $17,800 \mathrm{Btu} / \mathrm{h}$ at $75^{\circ} \mathrm{F}$ ) occurs gradually over a period of about 10 minutes. The AHU fan is programmed to slow by $5 \%$ of the full speed of the active cooling step every 30 seconds. This downward trend occurs until the fan speed reaches $40 \%$ of full rated speed for the cooling capacity level at which the system is currently operating, but is not allowed to push evaporator coil temperature below $37^{\circ} \mathrm{F}$. As the air flow rate declines, the supply air temperature also declines, falling steadily to $55^{\circ} \mathrm{F}, 50^{\circ} \mathrm{F}, 45^{\circ} \mathrm{F}$, and even to $37^{\circ} \mathrm{F}$. At these lower air flow rates and lower supply air temperatures, SHR drops sharply. If the coil temperature reaches $37^{\circ} \mathrm{F}$, a low temperature limit is triggered (to prevent icing of the coil) and the fan air flow rate jumps suddenly to about $530 \mathrm{cfm}$ (system capacity typically still at minimum), raising the supply air temperature to near $60^{\circ} \mathrm{F}$ within a period of about one minute. After running at this higher fan speed for a short period of time, it reverts again to RH control mode with gradually slowing fan speed and declining supply air temperatures. The entire cycle often takes about 15 to 20 minutes from start to finish and will repeat itself many times throughout the day as long as indoor RH (measured by the humidity sensor in the thermostat) is above the user-selectable RH set point. The RH control mode will allow cooling operation to continue until the indoor temperature declines to 2 degrees below the set point.

The desired RH set point can be selected in 5-percentage point increments (e.g., 55\%, 50\%, 45\%, etc.). While the iQ Drive system will try to achieve the desired RH level, it cannot necessarily achieve or maintain the RH set point during any given time period. For example, in our Phase 1 experiments (3-ton system), the RH control set point was set to $45 \%$, but the resulting 24 -hour monitored indoor $\mathrm{RH}$ was about $52 \%$ on average (this was about 2 percentage points lower than what was produced by the standard control mode). The iQ Drive thermostat has an on-board humidity sensor. As long as the room RH (as sensed by the thermostat) is above the RH set point, the iQ Drive control algorithms will lower AHU fan speed to produce a colder coil and reduced SHR. Furthermore, the RH control set point will not activate the cooling system; it will simply optimize latent performance when space cooling is called for based on the thermostat dry bulb temperature setting. Therefore, the iQ Drive system will not control indoor RH during the hours of the day when the system has cycled off.

In heating mode, the iQ Drive heat pump varies capacity and AHU fan speed in much the same manner as the standard cooling mode. Instead of cycling off, compressor speed and capacity decline as the room air temperature rises relative to the thermostat set point. AHU fan speed also declines, but not as precipitously as the compressor speed and capacity. Heating has 12 steps of heat delivery where the system goes to step 11 if the room temperature drops to more than 4 degrees below set point. If the heat pump cannot satisfy demand after 10 minutes at step 11 (106\% of rated capacity), then step 12 is called for, which enables electric strip auxiliary heating or hydronic coil, neither of which was installed on the system used in these experiments.

\subsection{Extended System Run Time Causes Increased Duct Losses}

The issue of greater duct conductive losses had been previously identified for variable-capacity space systems. Andrews (2002), when addressing variable-capacity heating systems, pointed out 
that installation of a "modulating furnace in a conventional duct system" may result in substantial increase in energy losses due to the longer dwell time of supply air within the ducts." The same principal would apply to capacity modulation provided by variable-capacity heat pumps in both cooling and heating modes. The purpose of the experiments presented in this report is to test the hypothesis that a higher efficiency air distribution system yields greater improvement in overall system efficiency for a variable-capacity system relative to a fixedcapacity system and that this difference is big enough to justify additional cost for mitigation measures. The term $d$ well is used in this report to refer to the amount of time distributed air spends inside ductwork during space conditioning cycles. Longer run times mean greater dwell time and therefore a greater period of time of exposure to conductive gains and losses. 


\section{Setting Up the Experiments}

An experimental facility called the MH Lab, located on the Florida Solar Energy Center (FSEC) campus in Cocoa, Florida, was selected to carry out these experiments. The MH Lab is a 1,600 $\mathrm{ft}^{2}$ double-wide manufactured home with a crawl space, a vented attic, three bedrooms, and two bathrooms. The house was manufactured in January 2002. Two Nordyne 2-ton heat pumps, one a SEER 13 fixed-capacity system and the other a SEER 22 iQ Drive variable-capacity system, were installed in the lab and connected to a duct system located primarily in the attic. (The lab also has an interior duct system, but it was not used in these experiments.) Return air ductwork, which consists of a short plenum/filter assembly, is located completely within the conditioned space adjacent to the AHUs. The duct leakage from outside the conditioned space, known as $\mathrm{Q}_{25, \text { out }}$,for the return ductwork was therefore $0.0 \mathrm{cfm}$. A small portion of the supply ductwork is located in the conditioned utility room. The vast majority of supply ductwork, which has nominal R-6 insulation, is located in the attic. Measurements of airtightness and duct operating pressure found that operational supply duct leakage to outdoors (attic) was on the order of $5 \mathrm{cfm}$, or about $0.5 \%$ of system flow. Midway through these experiments, insulation levels of the attic ducts were upgraded. A discussion of the duct insulation retrofits is presented in Section 2.3.

\subsection{Data Acquisition and Measurement Equipment}

A data acquisition system was installed to record a variety of information regarding heat pump operation, energy consumption of various items within the house (including internally-generated sensible and latent loads), and indoor and outdoor conditions. Internal loads, typical of a family of three persons, were generated and monitored. Temperature and RH of air flowing into and out of the heat pump system are recorded only when the heat pump is operating (conditionally). A list of test equipment and monitoring sensors is presented in Table 2. 
Table 2. Lab Testing and Monitoring Equipment Used in the Phase 1 and Phase 3 Experiments

\begin{tabular}{|c|c|}
\hline Measurement & Equipment \\
\hline Data collection & $\begin{array}{c}\text { Campbell Scientific CR10 with (2) AM416 } \\
\text { multiplexers and (1)SW8A pulse expansion } \\
\text { module }\end{array}$ \\
\hline $\begin{array}{l}\text { Pressure differentials (air flow sensors, air } \\
\text { distribution pressures) }\end{array}$ & DG-2 digital pressure gauge with analog output \\
\hline Return system air flow (in situ calibration) & Shortridge Velgrid \\
\hline Duct leak air flow (in situ calibration) & Continental Fan Manufacturing Iris Damper \\
\hline Air flow calibration & TSI Model 8390 Bench Top Wind Tunnel \\
\hline $\begin{array}{l}\text { Supply grill air flow } \\
\text { temperature }\end{array}$ & $\begin{array}{l}\text { Energy Conservatory FlowBlaster } \\
\text { Type T thermocouple }\end{array}$ \\
\hline $\begin{array}{l}\text { RH (return, supply, blended duct leak, indoor, } \\
\text { outdoor, attic) }\end{array}$ & Vaisala HM34 and HMP50 \\
\hline AC condensate & $\begin{array}{l}\text { Texas Electronic TR-4 and TR-525I tipping } \\
\text { buckets }\end{array}$ \\
\hline $\begin{array}{l}\text { Energy (whole house, } \mathrm{AHU} \text {, condenser unit, DHW, } \\
\text { oven, refrigerator, dishwasher, heat lamp circuit) }\end{array}$ & $\begin{array}{l}\text { Continental Wattnode and Ohio Semitronics Inc. } \\
\text { energy transducers with current transformers } \\
\text { from } 5 \text { to } 200 \text { amps }\end{array}$ \\
\hline DHW water consumption & Kent C700 Flow Meter \\
\hline Latent delivery & FMI Lab Pump Jr. model RHSY \\
\hline Building envelope air leakage & $\begin{array}{l}\text { Minneapolis Blower Door System with DG-700 } \\
\text { digital gauge }\end{array}$ \\
\hline Duct system air leakage & Minneapolis DuctBlaster System with DG-700 \\
\hline Automation internal loads & $\begin{array}{l}\text { Insteon based load switches controlled by ISY-99i } \\
\text { Automation controller }\end{array}$ \\
\hline Duct surface moisture presence & $\begin{array}{l}\text { Detec Moisture Detection Tape (MDT) part of the } \\
\text { Detec PermaScan-C System }\end{array}$ \\
\hline
\end{tabular}

- Temperatures were recorded conditionally (conditionally means data is collected when the system is operating) at the entry to the return plenum (which is in the conditioned space and is less than 2 feet long), the discharge from the AHU, and at five supply registers (the latter for only the attic duct system). Temperatures are recorded entering the condenser coil (outdoor unit) when the system is operating. 
- Temperatures were also recorded unconditionally (continuously) at various indoor locations, in the attic, in the crawl space, and at various locations on the roof system.

- RH was recorded conditionally at the entrance to the return and the discharge from the AHU.

- RH was also recorded at various indoor locations, in the attic, in the crawl space, and outdoors, all unconditionally (continuously).

- The air flow rates of the two systems were recorded at the entrance to the return.

- Power meters were installed to record energy use for the house, the heat pump outdoor units, the heat pump AHUs, the refrigerator, the domestic hot water heater, the oven, air circulation fans, heat lamps that simulate internal loads, and the dishwasher.

- Condensate draining from the AHU was measured by a pair of tipping buckets (installed in series), which provide redundant measurement of moisture removed by the cooling coils.

- Weather conditions of air temperature, $\mathrm{RH}$, rainfall, wind speed/direction, and solar radiation (on the horizontal) were recorded.

\subsection{Internal Loads to Simulate Occupancy}

The MH Lab is an unoccupied home. In occupied homes, the activities of occupants and appliances generate heat, which adds to the cooling load and subtracts from the heating load. This added heat is in the form of both sensible heat and latent heat. Internal sensible and latent loads were implemented using guidance from the Building America Research Benchmark Definition (Hendron 2008). An automation system was installed to control the production of internal loads (both sensible and latent) to simulate occupancy of a three-person family. A detailed discussion of internally-generated loads and occupant activities is presented in Appendix A of the Phase 1 report (Cummings and Withers 2011), which contains schedules of occupant activities and internal loads.

\subsection{Duct Insulation Retrofit}

This report presents the results of adding insulation to the existing attic duct system of the $\mathrm{MH}$ Lab. The following discussion describes the existing attic duct system and the modifications that were done to increase the thermal resistance of the ducts.

\subsubsection{The Pre-retrofit Duct System}

The pre-retrofit duct system consisted of the following:

- The return air is located entirely within the conditioned mechanical room.

- About $11 \%$ of the total supply ductwork surface area is located in the conditioned mechanical room.

- The remaining supply ductwork, all of which is located in the attic, consists of 2 main trunks and 10 supply branches serving 10 supply registers, primarily consisting of R-6 flex duct with some plenum/junction boxes (Figure 3). 


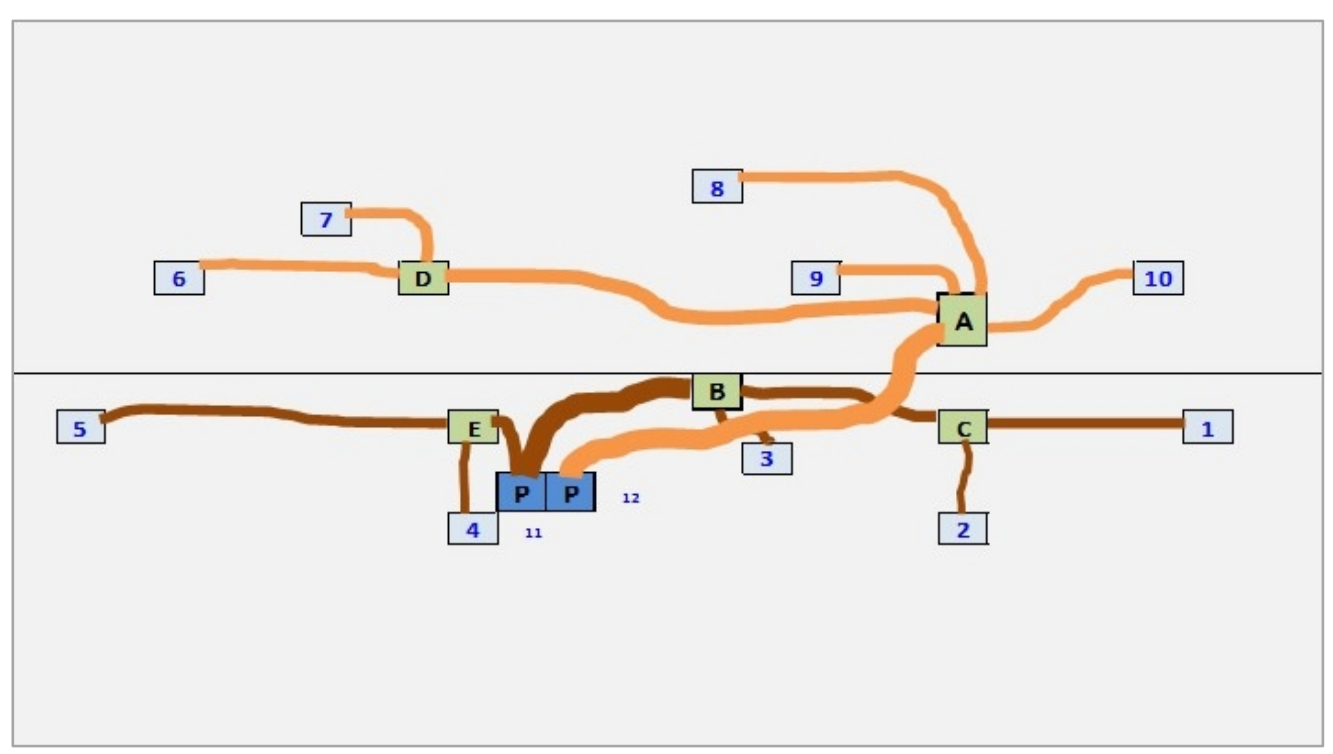

Figure 3. Layout of the attic ductwork in the MH Lab, showing two supply plenums (P), five supply junction boxes (A through E), flex ducts, which vary in size from 5 to 12 inches in diameter, and 10 supply terminal register drops (1 through 10$)$

Table 3 lists the diameter, length, and surface area of the flex duct, which have inner diameters that range from 5 to 12 inches.

- The combined surface area of the flex ducts, prior to retrofit modifications, was $447 \mathrm{ft}^{2}$.

- There are six R-6 fibrous board plenum/junction boxes in the attic, which have a combined surface area of $28 \mathrm{ft}^{2}$.

$\circ$ The main east supply plenum has a surface area (within the attic) of $11 \mathrm{ft}^{2}$.

$\circ$ The west plenum is very short and is almost entirely in conditioned space. The small top amount in the attic has been accounted for in the duct section PB.

- The five junction boxes have a combined surface area of $17 \mathrm{ft}^{2}$. 
Table 3. Various Components of the Attic Duct System (from Figure 3) are Labeled. Flex Duct Sections are Identified by Grill Number and Junction Box. Plenum and Supply Junction Boxes are Identified by a Single Letter.

\begin{tabular}{|c|c|c|c|c|}
\hline Type & Duct Description & $\begin{array}{l}\text { Duct Section } \\
\text { I.D. }\end{array}$ & $\begin{array}{l}\text { Round Duct Inner } \\
\text { Diameter (Inches) }\end{array}$ & $\begin{array}{c}\text { Surface Area } \\
\left(\mathrm{ft}^{2}\right)\end{array}$ \\
\hline Flex & SE bedroom & $1 \mathrm{C}$ & 6 & 18.8 \\
\hline Flex & Hall bath & $2 \mathrm{C}$ & 5 & 6.3 \\
\hline Flex & Kitchen & $3 B$ & 5 & 7.3 \\
\hline Flex & Utility room & $4 \mathrm{E}$ & 5 & 10.5 \\
\hline Flex & Master bath & $5 \mathrm{E}$ & 6 & 45.9 \\
\hline Flex & Master bedroom & $6 D$ & 8 & 35.3 \\
\hline Flex & Living room & $7 D$ & 6 & 9.4 \\
\hline Flex & Front entry & $8 \mathrm{~A}$ & 6 & 37.7 \\
\hline Flex & Dining room & $9 A$ & 5 & 13.6 \\
\hline Flex & NE bedroom & $10 \mathrm{~A}$ & 5 & 9.4 \\
\hline Flex & Plenum to junction $\mathrm{B}$ & PB & 12 & 43.2 \\
\hline Flex & Plenum to junction $A$ & PA & 12 & 84.4 \\
\hline Flex & $\begin{array}{c}\text { Junction } B \text { to junction } \\
\text { C }\end{array}$ & $\mathrm{BC}$ & 8 & 31.7 \\
\hline Flex & Plenum to junction $\mathrm{E}$ & PE & 8 & 10.1 \\
\hline Flex & $\begin{array}{c}\text { Junction } A \text { to junction } \\
\text { D }\end{array}$ & $A D$ & 10 & 83.4 \\
\hline Fibrous board & East plenum & $P$ & & 11.1 \\
\hline Fibrous board & Junction box $A$ & A & & 5.1 \\
\hline Fibrous board & Junction box $B$ & B & & 3.7 \\
\hline Fibrous board & Junction box C & C & & 1.2 \\
\hline Fibrous board & Junction box D & D & & 4.8 \\
\hline Fibrous board & Junction box $\mathrm{E}$ & $E$ & & 2.5 \\
\hline
\end{tabular}

The surface area of the entire attic supply duct system was $475 \mathrm{ft}^{2}$, indicating a duct-toconditioned floor area ratio of 0.297 . This is in line with a study performed by Andrews in 2002. He found that 10 homes with average conditioned floor area of $1,502 \mathrm{ft}^{2}$ had an average of 470 
$\mathrm{ft}^{2}$ of supply duct surface area for the 11 heating systems. Supply duct-to-floor area ratios ranged from 0.24 to 0.38 for these 11 systems, with an average ratio of 0.31 .

A substantial portion of the surface area of the lab house duct system was in contact with the cellulose attic floor insulation. A detailed inspection of the attic ducts found that at least some portion of every duct was in contact with the blown cellulose insulation. Based on visual inspection, it is estimated that about $20 \%$ of the total duct surface area is in contact with the loose-fill cellulose. The attic was insulated with an average of about 9 inches of blown cellulose, which was as deep as 12 inches in a few areas. In a number of places, flex ducts had settled into the existing attic insulation to where $5 \%-25 \%$ of the lower portion of the duct was surrounded by cellulose insulation. A few small sections of duct (about 1\% of total duct area) were found to be lightly covered by attic insulation, as shown in Figure 4. Small portions of kitchen branch duct 3B and master bath duct 5E were buried (see Figure 3 and Table 3 for duct section I.D.s).

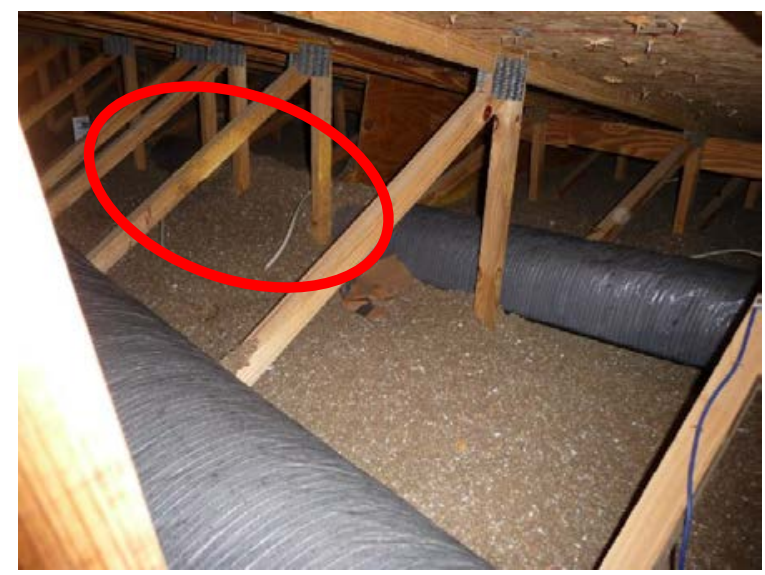

Figure 4. Flex duct section 8A partially covered by attic insulation prior to being wrapped with insulation

\subsubsection{The Duct Insulation Retrofit}

The duct insulation retrofit consisted of the following:

- Foil-faced duct insulation wrap was installed on the exterior of the existing duct system. It was desired that the duct system would remain unaltered, except for R-value and emissivity characteristics, so that air flow rates and distribution patterns would remain unaltered. Therefore, the retrofit was implemented in such a way that the ducts would remain in the same place and maintain the same shape that they had prior to retrofit. The interior liner of the ductwork would then have the same surface area before and after retrofit.

- The duct wrap has foil facing and 2.2 inches of fiberglass batt, with a rated R-value of 7.4 when installed uncompressed (2.2" thickness). It is also rated to have an R-value of 6 if compressed to 1.65 ". It is estimated that no compression of the batts occurred except in a few locations where the ducts passed through trusses or were in close contact with other ducts. These compressed areas are estimated to be about $2 \%$ of total duct system surface area. The insulation wrap foil facing has a rated water vapor permeance of 0.02 perms. 
- The duct wrap was not installed around the entire circumference of the ducts, but rather was applied only to the portion of the ducts that were exposed directly to the attic air. The approximately $20 \%$ of ductwork that was "buried" in (in contact with) the attic floor cellulose loose-fill remained largely unaltered. This approach was used in order to reduce the chances of moisture condensing on the ducts and dripping onto the ceiling.

- Duct wrap sections were cut in lengths that were as long as possible to minimize the number of seams. Seams were taped with metal tape, when possible, to minimize condensation potential.

- Figure 5 shows a section of the twelve-inch inner diameter main duct branch PA before the insulation blanket was added. It can be seen that the flex duct rests on top of the attic insulation. The foil-faced insulation batts were then draped over the existing ducts and trimmed so that they came down to where the exterior side walls of the original ducts met the loose-fill cellulose insulation located on the floor of the attic. The lower extremity of the wrap was then tucked slightly into the cellulose floor insulation. To complete the installation, a small amount of cellulose was mounded on the outside of the wrap (against the duct wrap foil) to hold the wrap in place reasonably tight against the duct. The stages of duct wrap installation are shown in Figure 6. The insulation wrap has been added and a portion of cellulose insulation added at the new insulation edge. The cellulose edge was generally triangular in shape and 2 inches high with a base of about 2-3 inches. This small amount of extra cellulose insulation was brought into the attic specifically for this purpose.

- Insulation wrap was also applied around plenum and junction fibrous board boxes. Figure 7 shows a supply plenum after insulation was added. The seams were taped using scrimreinforced metal tape applied with a squeegee.

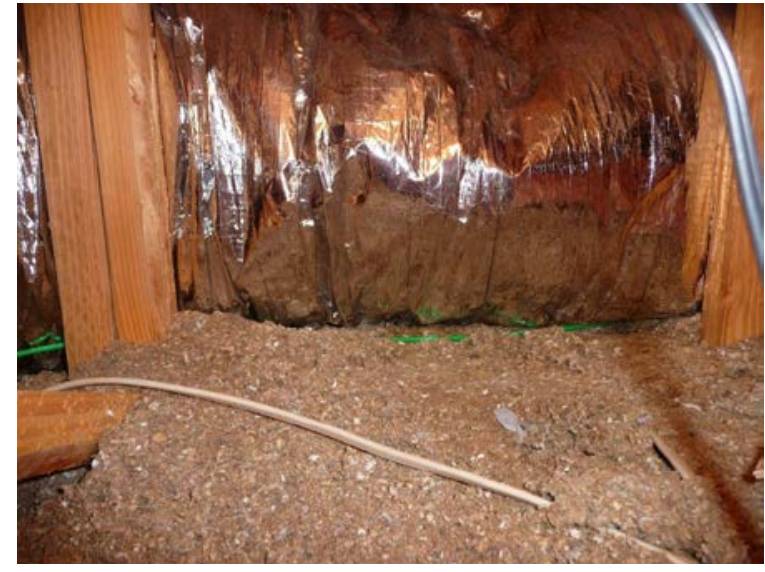

Figure 5. Duct section PA located about three feet downstream of supply plenum prior to insulation 


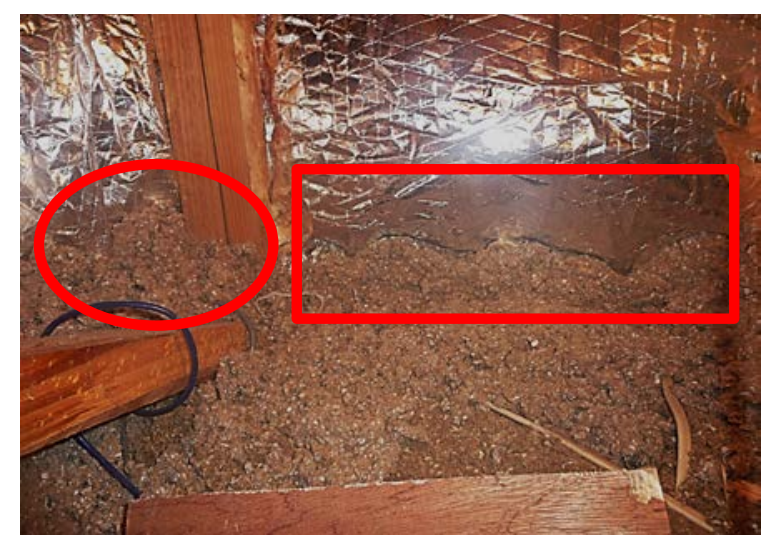

Figure 6. Duct section PA after insulation wrap has been installed. In the red rectangle, the foil facing will be tucked under and cellulose added. In the red circle, the foil facing has been tucked under, and a small amount of cellulose insulation has been added where the duct wrap meets the existing cellulose.

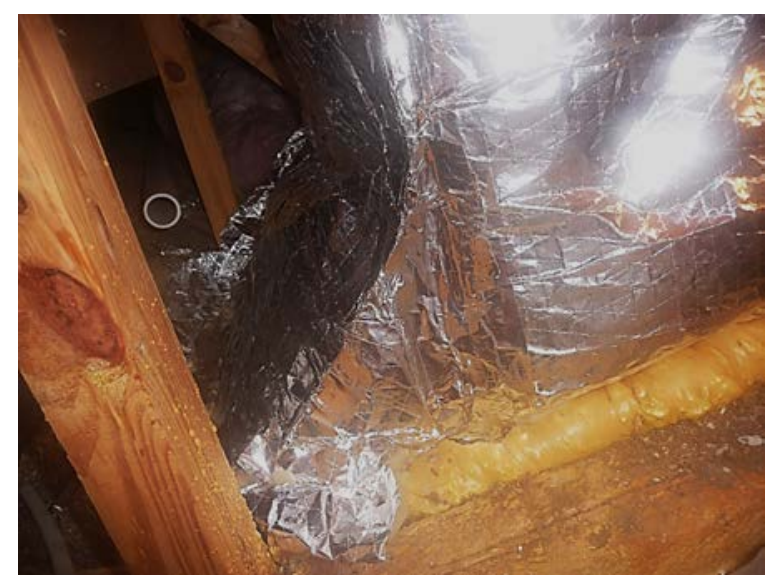

Figure 7. A supply plenum box after insulation wrap was applied. Insulation seams were sealed with reinforced metal tape applied with a squeegee.

- The general concept underlying this duct wrap installation approach was as follows:

- The research team was aware of considerable potential for condensation on at least portions of cold supply-air duct surfaces throughout the summer if the foilfaced duct insulation added could not be effectively sealed around each duct.

- The very small attic and very tight space between truss members did not allow ample working space to guarantee effective seals around the ducts.

- A compromise was made to insulate most of the duct surface area, but not cover the bottom portion where the duct would be coldest or where water could be trapped.

The research team expected that moisture (in the form of water vapor in the attic air) would migrate into the space between the duct wrap foil and the outer jacket of the existing ducts. Because of the duct wrap, the outer jacket of the existing duct would become cooler than it had previously been so that moisture condensation would be quite likely. Figure 8 shows the daily pattern of attic temperature compared to the outdoor temperature during hot summer period. Figure 9 shows the daily pattern of attic temperature and attic air dewpoint. The average daily 
attic dew point temperatures are in the range of $70^{\circ}-80^{\circ} \mathrm{F}$ in Figure 9 and are at least $70^{\circ} \mathrm{F}$ almost all the time for about 5 months per year in climate regions 1 and 2 .

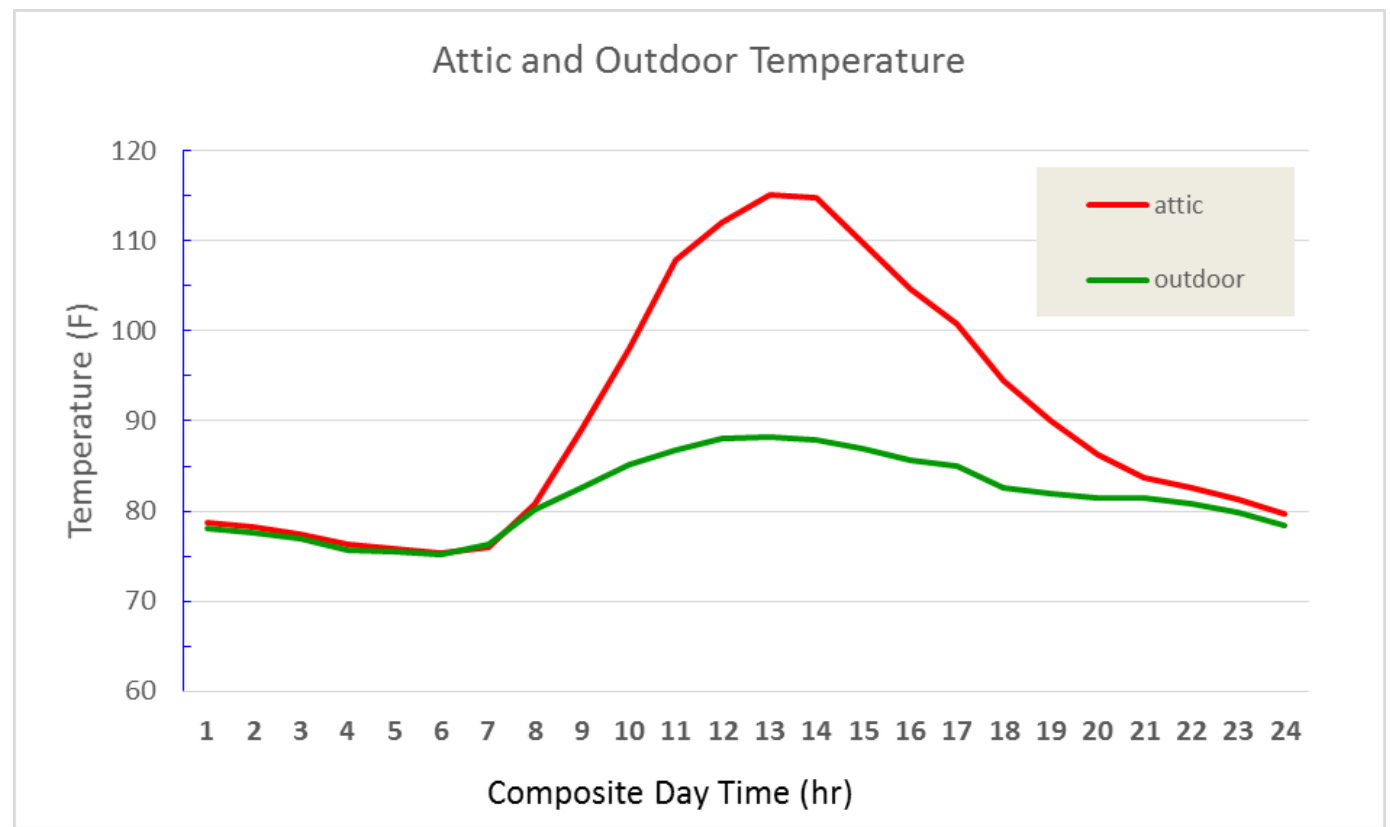

Figure 8. Attic and ambient dry-bulb temperatures with $\mathrm{T}_{\text {ambient,avg }}=81.6^{\circ} \mathrm{F}, \mathrm{T}_{\text {attic,avg }}=90.5^{\circ} \mathrm{F}$, and near full sunshine, shown as daily composite plot for July 27-August 1, 2013

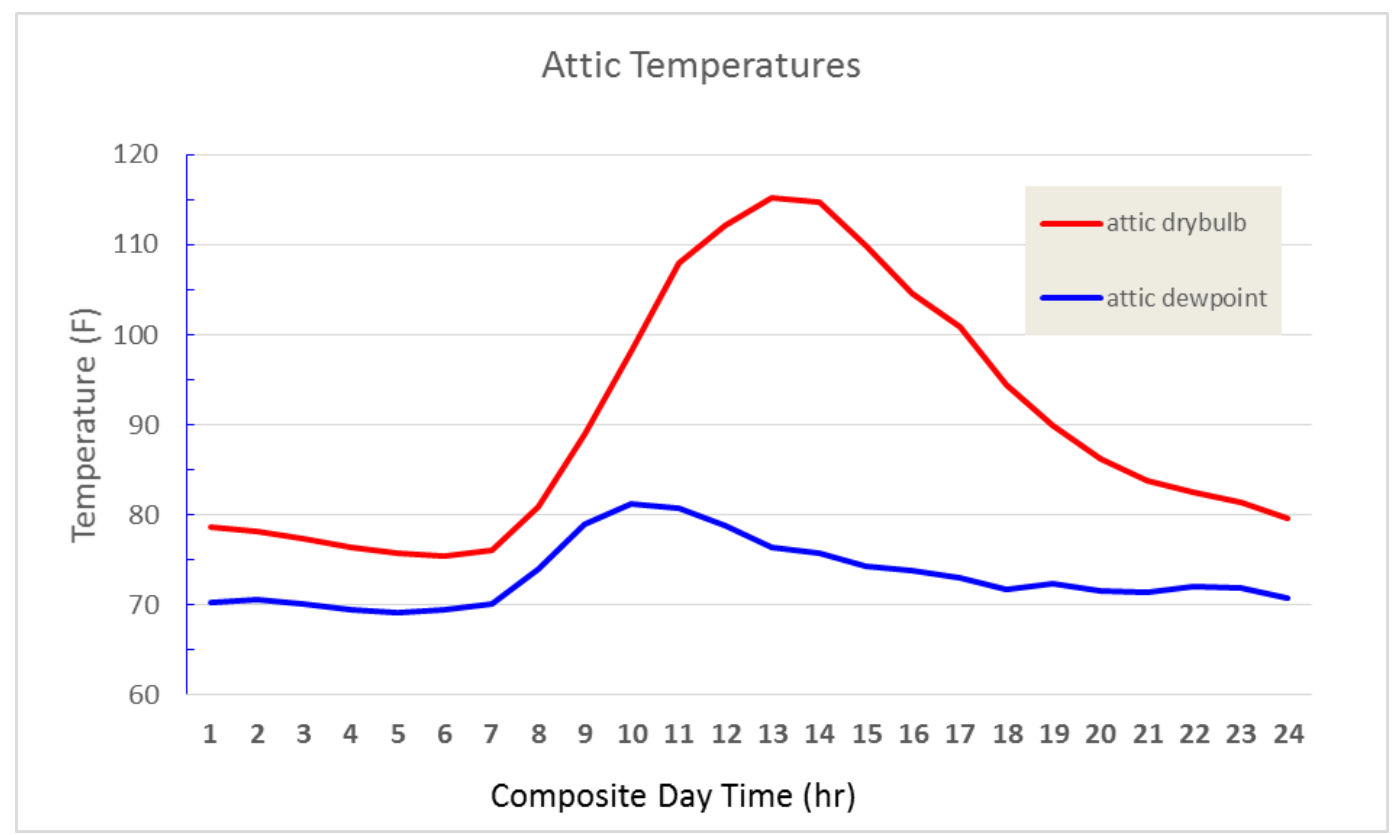

Figure 9. Composite attic dry-bulb (red) and dew point (blue) temperatures ( $\left.{ }^{\circ} \mathrm{F}\right)$ for July $27-$ August 1, 2013 at the MH Lab

In order to avoid this moisture migration, it would have been necessary to wrap the entire circumference of the duct and carefully tape the longitudinal and horizontal seams of the duct wrap, so that essentially no moisture could find its way into the space between the foil and duct outer jacket. Very tight attic space conditions greatly limited mobility and the ability to 
manipulate materials within the attic. The highest clearance in the attic starts at about 3 feet in the middle of the attic and tapers down with a 3 in 12 roof pitch. A few sections of duct had also been squeezed between truss members where adding more insulation would have caused more compression. Duct wrap seams were positioned at the truss sections and could not be taped.

Furthermore, fully wrapping and taping the duct insulation wrap would likely have caused some alteration of the location and shape of the flex ducts, producing some nonconformity between the pre- and post-retrofit duct system.

The research team anticipated that moisture condensation would occur on some areas of the newly-insulated ducts at least some of the time. It was expected that if moisture condensed on the outer jacket of the existing ducts, it would drain down to where the (original) duct outer jacket met the attic floor cellulose insulation. Furthermore, it was our expectation and hope that any condensed moisture in contact with the loose fill cellulose would be wicked away from the contact area through the cellulose material to areas with good drying potential.

To help keep track of this process, moisture sensors were positioned on the bottom of ductwork at two locations. The first duct surface moisture measurement location was on duct section PA (see Figure 3 ) within 3 feet of the main supply plenum. The second location was under section $10 \mathrm{~A}$ about 26 feet downstream from the supply plenum. This provided measurement at a worstcase moisture potential and moderate moisture potential location.

The moisture sensors used were only components of a complete moisture detection system offered by Detec, which is designed to provide early warning of water intrusion into roofing assemblies. The company does not typically sell only the moisture detection tape component of the whole detection system, but was willing to provide it to a nonprofit organization. When connected to a low 5-volt source, the sensor indicates a relative level of moisture based on electrical resistance. The voltage measurement was recorded using the lab data acquisition system. This same principle is commonly used in other moisture meters (James 1988). The sensor material measured the voltage drop in millivolts across two metallic strips imbedded onto a thin porous fabric substrate that was adhered to the duct surface. These same moisture sensors have been successfully used in another project that evaluated the condensation potential of attic ducts covered by blown cellulose insulation (Chasar and Withers 2013).

Moisture readings were observed on a regular basis to see moisture accumulation trends. The ceilings of the lab house located beneath supply ducts were visually inspected several times per week, with the observer standing within the conditioned space. An infrared camera and a handheld moisture meter were also used on occasion to look for indications of increased moisture content in the ceiling. No evidence of moisture accumulation was observed at any ceiling location in the MH Lab throughout the experiments. No indication of microbial growth or any other discoloration was observed on the ceilings.

Moisture sensor readings for the two duct locations are shown in Figure 10 for the period from August 30, 2013-November 2, 2013. The readings are in millivolts (mV) with Figure 10 showing a red horizontal reference line at $800 \mathrm{mV}$ where the duct surface would have liquid water condensing on it at that location. The lower black horizontal reference line is at about a level where the surface has not yet condensed water, but the surface humidity would be about 
$90 \% \mathrm{RH}$ or greater (high surface $\mathrm{RH}$ ). One of the sensors detected relatively high and continuous moisture content on the duct surface and in the immediately adjacent loose-fill cellulose insulation during this entire period. The other showed a pattern of reduced moisture condensation as ambient (outdoor and attic) dew point temperatures declined during the autumn period.

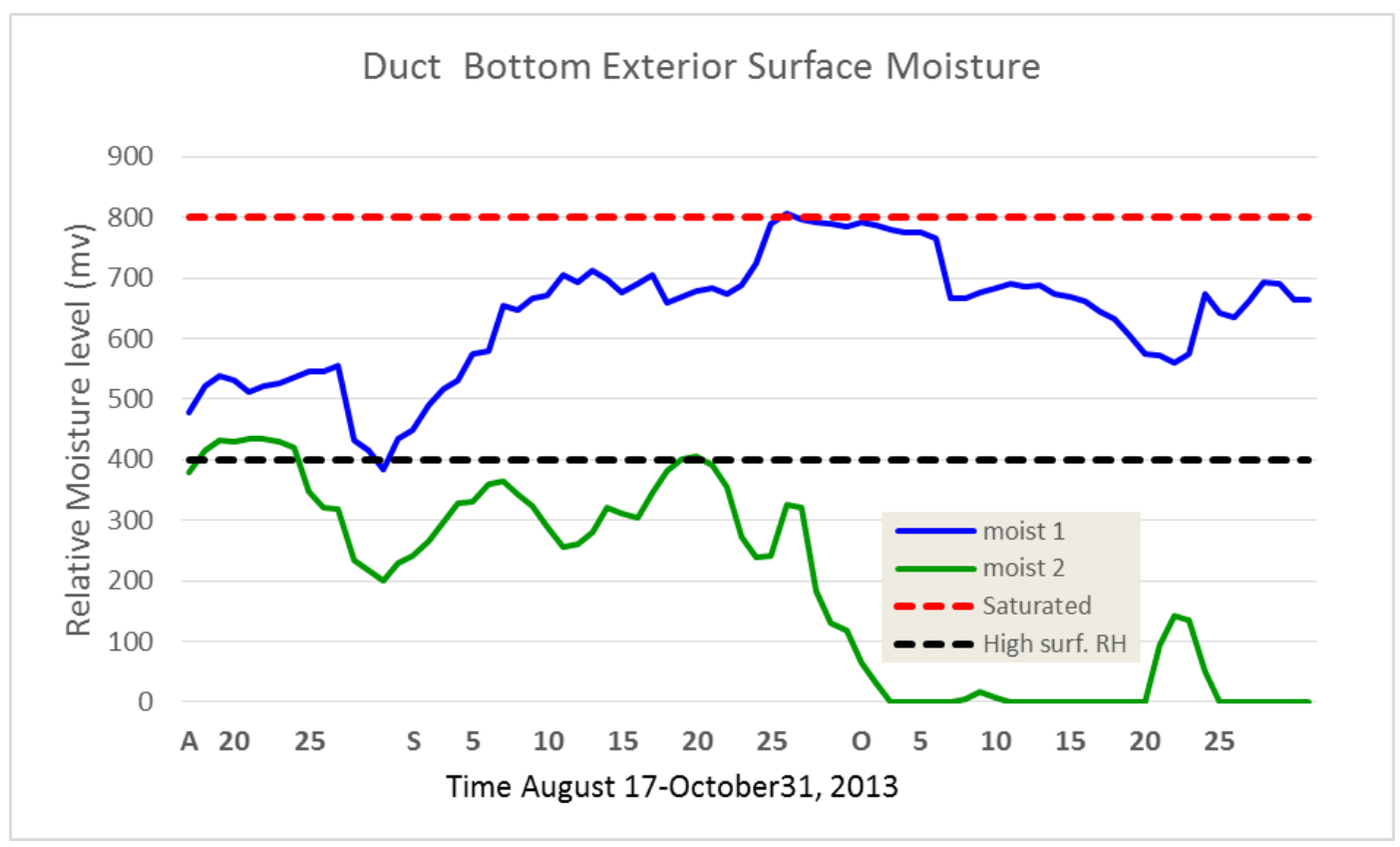

Figure 10. Moisture readings at two duct locations for the period August 30-November 2, 2013

On one occasion during a post-retrofit summer period, visual inspection - including sampling of the cellulose insulation by tactile contact - was performed in the attic. It was found that the first $1 / 8$ inch of cellulose immediately below the duct was wet to the touch at duct section PA near the supply plenum. Liquid moisture could be extracted by squeezing a sample. However, within 2 inches below the duct, the cellulose was essentially dry. When pulling one's hand from within the attic floor insulation more than 2 inches below the duct, it was found that fingers coming from the lower level of cellulose (closer to the ceiling gypsum board) were covered by dry dusty cellulose product that would be consistent with the cellulose loose-fill being dry.

Insulation moisture was also evaluated by measurement of air moisture content within collected samples of insulation. One set of insulation samples was collected from the two areas where the moisture sensors were located. Sample 1 was collected at the first sensor location 3 feet from the plenum and included the first inch of cellulose insulation directly below the duct PA. Sample 2 was collected from insulation material located about 1 inch above the ceiling gypsum board or about 8 inches beneath Sample 1. Sample 3 was taken from the more remote location immediately under duct section 10A about 26 feet downstream from the plenum. Sample 4 was collected from insulation material located about 1 inch above the ceiling gypsum board or about 8 inches beneath Sample 3. Figure 11 shows the moisture content (humidity ratio) of air contained within the insulation. The samples were collected and measured as follows:

1. New sealed heavy duty "zip-lock" bags were taken into the attic and sample location marked on bag. 
2. An insulation sample was collected; the bag was then immediately opened, a sample was placed inside, and the bag was immediately sealed.

3. The sample was brought out of the attic and allowed to come to a steady state condition with room temperature while still within the sealed bag.

4. A Vaisala HM34 probe was carefully inserted into a tight port in the bag where the air temperature and $\mathrm{RH}$ were measured.

5. The temperature and $\mathrm{RH}$ measurements were then converted to air moisture content (gr/lb; Figure 11).

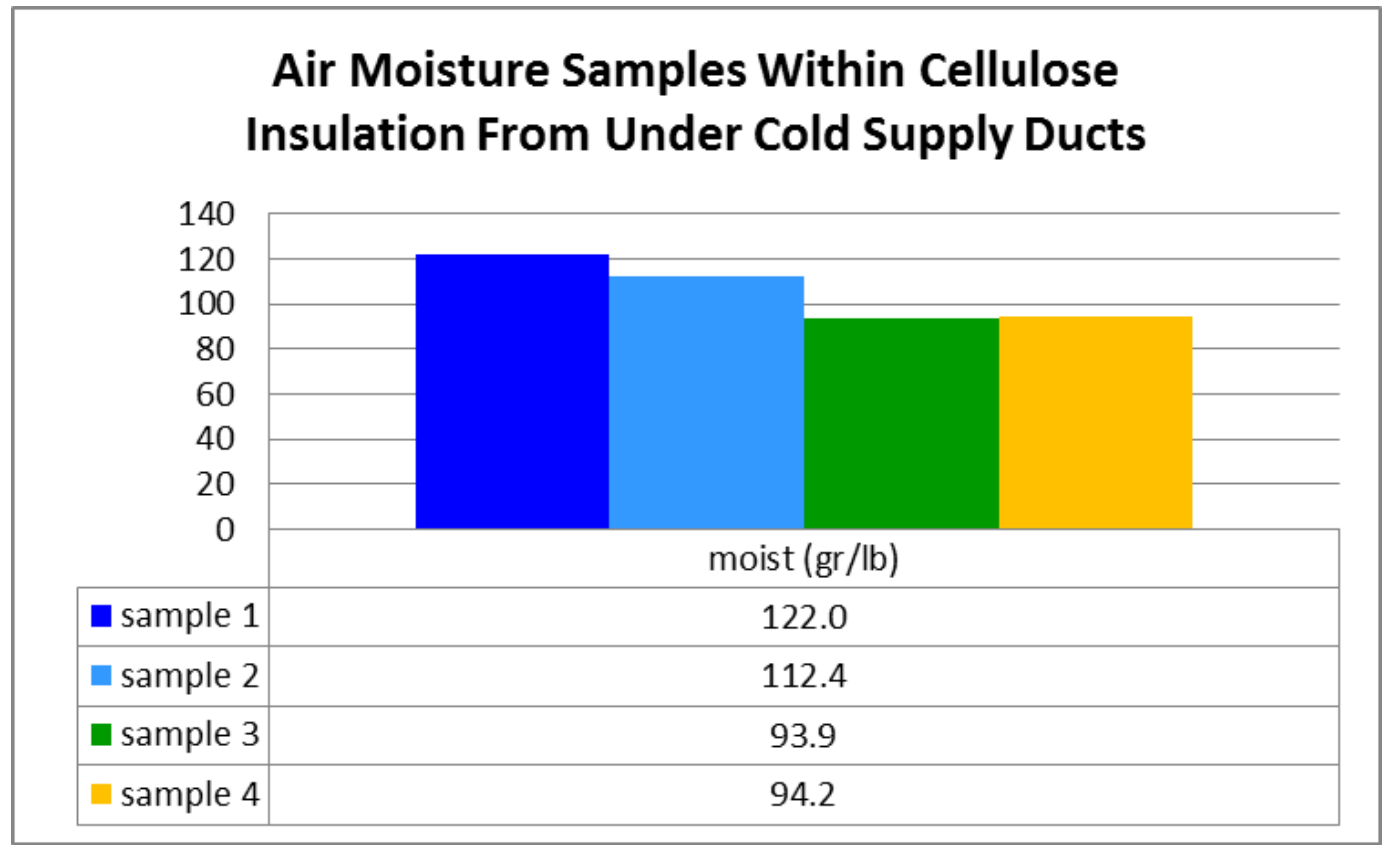

Figure 11. Moisture content of the air within cellulose insulation taken from under duct sections PA (samples 1 and 2) and 10A (samples 3 and 4)

While this does not provide a direct measurement of insulation moisture content, it does show a general trend that agrees with the visual and tactile inspection. Based on these measurements, the authors draw the following conclusions:

- The insulation immediately below the plenum had air moisture content about $30 \%$ higher than in the insulation immediately under the ducts located 26 feet downstream.

- The insulation about 9" below the plenum (near the gypsum ceiling) had an air moisture content about $20 \%$ higher than in the insulation about 9" below the duct located 26 feet downstream.

The research team has concluded that the cellulose insulation located on the floor of the attic has the ability to absorb moisture, wick moisture, transfer moisture in the form of water vapor to inter-fiber spaces, and eventually transfer water vapor to the attic air, and through this process avoid moisture accumulation problems. It could also be stated that moisture was accumulating on the outer surface of the original ducts and that this moisture was accumulating and penetrating into the upper layers of the cellulose loose-fill, but it did not become a (significant) problem (after several months of hot and humid weather) because the cellulose was sufficiently thick and 
had effectively dispersed the moisture back to the attic air space. It was able to dry to the attic because the attic was hot due to dark asphalt composite shingle on a wood deck. Effective drying may not have occurred if the roof surface had a high reflectivity such as white metal or high mass such as tile.

By contrast, it is anticipated that if the attic floor insulation had consisted of a lower density material such as fiberglass, there would be less capillary action. Materials having less capillary forces or moisture capacitance than cellulose would tend to favor more downward movement of collected moisture more readily as gravitational forces are able to overcome capillary forces. If the rate of condensation overcomes the rate of drying within the insulation material, water will move downward through the insulation towards the gypsum board of the ceiling below where water staining and mold growth are more likely to occur. It would be useful to perform experiments to compare the relative moisture outcomes when using fiberglass versus cellulose loose-fill attic floor insulation.

Duct moisture condensation would have an effect on R-value because of wetting of duct insulation material. Inspections during the pre-retrofit period had found that there was a small portion of wet cellulose at the same location near plenum PA previously discussed (sample 1 Figure 11). Based on limited inspection, the research team concluded that post-retrofit period had not resulted in any noticeable increase in duct surface condensation. It seems likely that the effect of damp insulation was small since it was limited to a small isolated area near the cold plenum. Therefore, the impact of damp insulation upon the difference between pre- and postretrofit periods are expected to have been negligible.

\subsection{Determining Pre- and Post-retrofit Supply Duct R-Values}

The supply duct system consists of flex ducts combined with supply plenums and junction boxes formed from fibrous duct board.

The following discussion applies to the supply ducts of the system referred to as the "attic duct system". The R-value of the return ducts is not under consideration because they were located completely within the conditioned utility room.

The project statement of work called for increasing the existing nominal R-6 ductwork to R-10+. There was no certainty that the actual effective R-value of the original ducts was in fact R-6, so the research team determined that our target was to increase actual effective R-value by $67 \%$ or more. At first thought, it would appear that the research team implemented a retrofit that would easily meet this target level of duct insulation enhancement. On the face of it, adding R-7 duct wrap to R-6 ducts would produce an R-13 duct system. However, the reality is more complex. The fact that an estimated $20 \%$ of the duct surface area was (and is) in contact with the loose-fill cellulose insulation on the attic floor, changes the situation significantly. Furthermore, the fact that the research team added R-7 wrap only to the approximate $80 \%$ of the duct surface area that is exposed to the attic air adds further complication.

Dry-bulb temperatures were measured (monitored) at the discharge of the supply plenum (as the air entered the ductwork located in the attic) and at each of the supply registers. A heat transfer model, discussed in detail in Appendix B, was implemented within a spreadsheet to determine the actual, effective duct system R-value for the pre-and post-retrofit duct systems based on the 
measured duct air temperature data. To complete these calculations, duct surface areas within the attic were measured as well as air flow rates for each branch of the duct system. Temperature rise was measured from the discharge of the supply plenum to each of the 10 supply registers using a Campbell Scientific datalogger and type-T thermocouple wire. Temperature was not, however, known at each junction of the distribution system. R-value was calculated based on data for summer day periods when the variable-capacity (SEER 22) system was forced to operate at a fixed-intermediate capacity and when attic conditions were fairly stable at near peak temperature for an extended period ( 1 hour or longer). Both air temperature and mean radiant temperature are taken into account in the R-value calculations. The measured data taken during steady state operation of the cooling system is available in Table B-1 of Appendix B.

\subsubsection{Calculation Method to Determine Effective R-Value}

The approach used to calculate the effective R-value of the supply ducts is based on measured data. The following measured data are required as input to the model:

- Supply air flow rate at the discharge of the AHU and of each diffuser

- Supply air temperature at the discharge of the AHU, which is also the entrance to the supply duct system

- Supply air temperature at the discharge of each of the 10 supply air diffusers

- Attic air temperature and air temperature inside the ducts (the latter was interpolated based on air temperatures at AHU discharge and supply register discharge)

- Duct exterior jacket surface areas and geometry including inside and outside duct diameters.

Measured air and surface temperatures are shown in Figure 12. Since longer runs of duct having more exposed surface area result in greater heat gain and more rise in measured supply register air temperature, the average representative supply air rise was weighted or normalized based on each representative duct section surface area. Each supply temperature was weighted by the relative proportion of duct surface represented by each section. The weighted average rise in supply air temperature from AHU to grills was $8.2^{\circ} \mathrm{F}$ before and $5.5^{\circ} \mathrm{F}$ after retrofit. Simply based on the decreased rise in grill temperatures, conductive heat gains to the ducts declined by $33 \%$ (during sunny hot period). However, given that the attic was about $2^{\circ} \mathrm{F}$ warmer during the post-retrofit period, the decline in conductive heat gain was actually greater than $33 \%$, as detailed in the following discussion. 


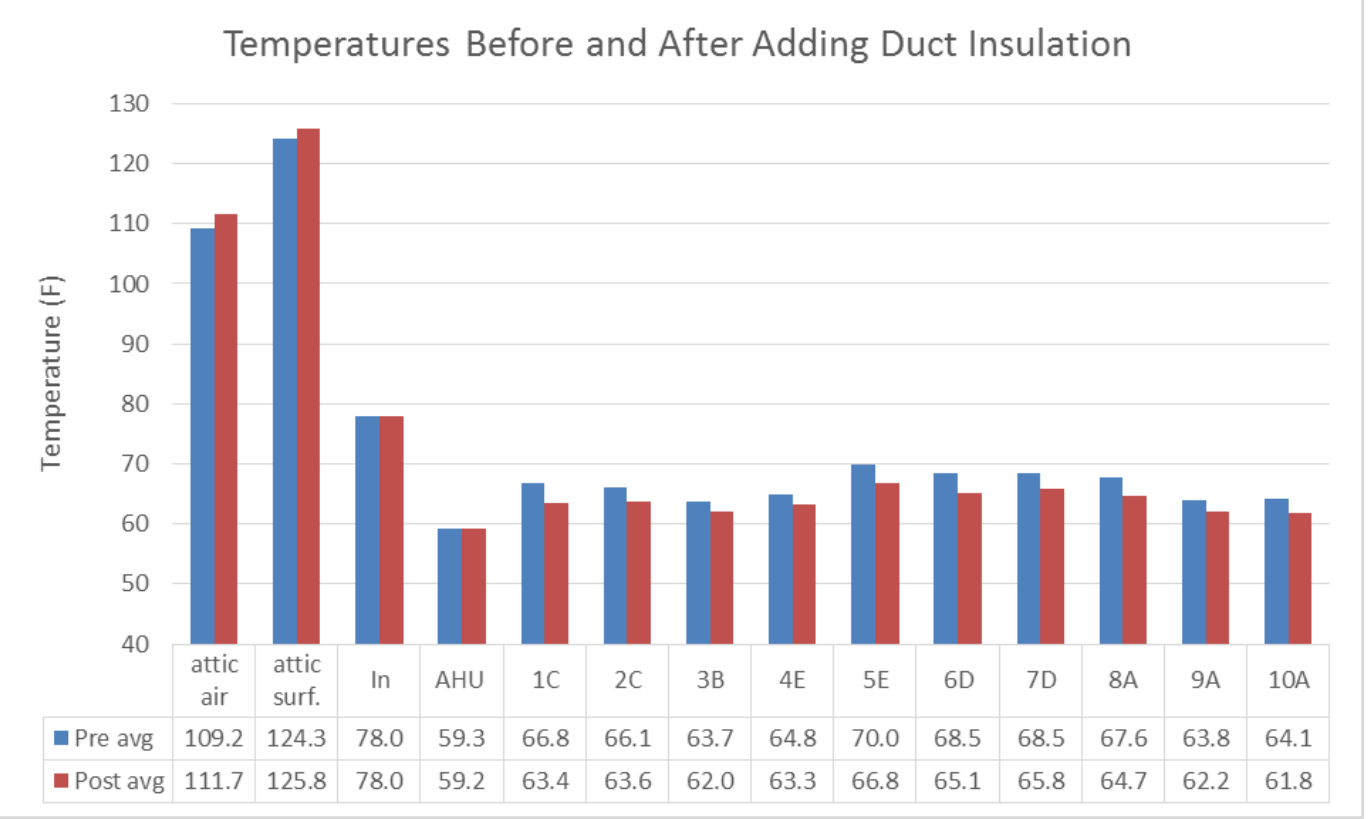

Figure 12. Attic, indoor, and supply air temperatures occurring during duct system R-value testing for pre- and post-retrofit periods

Consider the following temperatures for pre-retrofit:

- If we take the average supply air temperature in the duct system to be $63.4^{\circ} \mathrm{F}$ prior to retrofit and the combined attic air and surface temperatures to be $116.8^{\circ} \mathrm{F}$ prior to retrofit, then delta- $\mathrm{T}$ between attic and inside the duct is $53.4^{\circ} \mathrm{F}$ for the test prior to retrofit. Note that we have assumed equal weighting of attic air and surface temperatures as the basis for the combined attic temperature.

Consider the following temperatures for post-retrofit:

- If we take the average supply air temperature in the duct system to be $62.0^{\circ} \mathrm{F}$ after retrofit and the combined attic air and surface temperatures to be $118.8^{\circ} \mathrm{F}$ after retrofit, then delta- $\mathrm{T}$ between attic and inside the duct is $56.8^{\circ} \mathrm{F}$ for the test after retrofit.

- Delta-T between attic and inside the duct is then $6.4 \%$ greater in the post-retrofit period. If the pre-retrofit delta-T were $6.4 \%$ greater (making it comparable to the post-retrofit period), then the temperature rise from AHU discharge to average supply register discharge would have increased to $8.7^{\circ} \mathrm{F}$. Based on this adjustment for higher post attic temperatures, conductive heat gains declined by $37 \%$ as a result of the duct insulation retrofit.

The effective duct R-value is the R-value evaluated of the duct system installed as-is and is measured from the inner air duct liner surface to the outer exterior insulation jacket surface. Except where noted otherwise, the outermost insulation exterior surface area was used in our model prediction. Two different effective duct R-values have been calculated: 1) air-to-air and 2) surface-to-surface. The former includes the inside and outside film resistances and the latter does not. The air-to-air effective R-value is calculated first. This calculation is based on total duct heat transfer rate and area-weighted log mean temperature difference (LMTD) between the supply air 
stream and the environment temperature. The total heat transfer rate is calculated from air flow rates and rise in measured supply air temperatures from AHU discharge to registers.

The surface-to-surface duct R-value is backed out from the air-to-air R-value using duct inside and outside average air film resistance. The duct inside air film thermal resistance is estimated from a forced-flow convective heat transfer coefficient, and the duct outside air film thermal resistance is based on a combined resistance of free convection and radiation heat transfer coefficients from the duct outside surface to the environment. This procedure requires that the various temperatures and flow rates are measured under steady state conditions.

The following assumptions were made in the formulation of the procedure for effective R-value calculation:

- Steady state duct heat transfer

- The experimental data was collected during mid-afternoon periods when attic conditions would be reasonably stable, and the cooling capacity of the heat pump was set so that indoor (and return air) conditions would also remain fairly stable with continuous cooling input.

- No supply duct air leakage

- Actual supply duct air leakage was about $0.5 \%$ of system flow.

- Thermal mass of the ductwork is ignored, which is a safe assumption since the measured data occurred during periods of continuous, fixed-capacity cooling.

- The attic space temperature is considered to be the average of all attic temperatures measured in four different quadrants (NE, SE, SW, NW). There are four measurements representing the air temperature and four other measurements representing the attic surface temperature.

Details of the duct R-value calculation methodology are presented in Appendix B.

\subsubsection{Calculated Effective R-values}

\subsubsection{Pre-retrofit}

Pre-retrofit duct insulation R-values have been calculated (simulated) based on the temperature rise from the discharge of the AHU to the 10 supply registers, the temperature of the attic (air and radiant surfaces) and duct air, duct surface area, and duct air flow rates. The effective operational R-value of the attic supply ducts (as found) prior to retrofit was determined to be 6.1. Note that this is the effective operational R-value of the attic duct system including the existing flex ducts, the existing fibrous duct board boxes, and the approximately $20 \%$ of duct surface area in contact with attic floor cellulose insulation. Effective R-value of round duct has been found to vary from the nominal value based on diameter (Palmiter and Kruse 2006). The surface-areaweighted average inner duct diameter in the lab house attic is about 9.4 inches. After interpolating the R-value between 9 and 10 inches for a 9.4 inch duct diameter, the determined duct R-6.1 is only 2.8\% higher than R-value reported by Palmiter and Kruse in 2006. Given the inefficiencies of the installation such as duct insulation compression and other realities of actual flex duct installation compared to rated conditions, it is surprising that the values are this close. 
The portions of duct settled into the attic insulation are essentially responsible for improving the effective operational duct R-value.

For purposes of this study, the overall effective R-value of the attic supply ducts (including flex ducts, fibrous duct board boxes, and duct portions that are in contact with the attic floor loose-fill insulation) has been determined to be 6.1. It is, however, of some interest to disaggregate the operational R-value of the original nominal R-6 ducts, most of which are flex ducts, when the influence of attic floor insulation contact is removed. Another way to express this is to ask: what might the effective R-value be if there was no contact with attic insulation?

An estimate of the effective operational R-value of the original ducts (in the absence of contact with attic floor insulation) can be made, based on the formula:

$$
\mathrm{U} \text {-value }=\left(\mathrm{AF}_{1} \times 1 / \mathrm{R}_{1}\right)+\left(\mathrm{AF}_{2} \times 1 / \mathrm{R}_{2}\right)
$$

where

- $\mathrm{AF}_{1}=$ area fraction exposed to the attic air $(=0.8)$

- $\mathrm{AF}_{2}=$ area fraction in contact with attic insulation $(=0.2)$

- $\quad \mathrm{R}=\mathrm{R}$-value of duct as $1 / \mathrm{U}$.

Based on observation, $\mathrm{AF}_{1}$ is estimated to be $80 \%$ and $\mathrm{AF}_{2}$ is estimated to be $20 \%$. For these calculations, it is necessary to assign an R-value to the portion of the ductwork "buried" in the attic floor insulation. Work by Shapiro, Magee, and Zoeller (2013) reports effective R-values for partially buried round duct with nominal R-6 insulation at various duct diameters. In their work, effective R-values are shown at 8-inch inner diameter (effective R-10.2) and 10-inch diameter (R-11.4). These values indicate a drop by about $\mathrm{R}-0.6$ per inch.

$$
\text { Calculation: }(\mathrm{R}-11.4-\mathrm{R}-10.2) /(10 \text { in. }-8 \text { in })=\mathrm{R}-1.2 / 2 \text { in. }=\mathrm{R}-0.6 / \text { in. }
$$

Based on R-0.6 degradation per inch, as duct inner diameter decreases from 10 inches to 9.4 inches, effective R-value of the buried portion of duct is determined to be about R-11.0.

Next, using the derived overall duct R-value of $6.1(\mathrm{U}=0.164)$ and buried portion R-value of 11.0, the R-value for portions of the ducts exposed to attic air $\left(R_{1}\right)$ can be determined.

- $1 / 6.1=0.8 \times 1 / \mathrm{R}_{1}+0.2 \times 1 / 11.0$

- $0.164=0.8 / \mathrm{R}_{1}+0.018$

- $\mathrm{R}_{1}=0.8 / 0.146$

- $\mathrm{R}_{1}=5.48$ (R-5.48 is then the calculated R-value of the combination flex duct and fibrous duct board system prior to the retrofit that was not in contact with the attic floor insulation) 
Pre-retrofit duct R-value summary:

- The $20 \%$ of ducts that were in contact with attic floor insulation were determined to have an R-value of 11.0 when including the R-value boost that results from contact with the attic floor insulation.

- The $80 \%$ of the ducts that were not in contact with the attic floor insulation were calculated to have an effective R-value of 5.5.

- We conclude, therefore, that contact with the attic floor insulation has provided an Rvalue boost to the original ducts of 5.5.

- The overall pre-retrofit attic duct system R-value, including the R-value enhancement from duct contact with the attic floor insulation, was determined to be 6.1.

\subsubsection{Post-retrofit}

Post-retrofit duct insulation R-values have been calculated (simulated) based on the temperature rise from the AHU discharge to the 10 supply registers, the temperature of the attic (air and radiant surfaces) and duct air, duct surface area, and duct air flow rates. The effective operational R-value of the attic supply ducts, after implementation of the insulation wrap retrofit and including contact with the attic floor insulation, was determined to be 11.6 (both pre- and postretrofit effective R-values were calculated based on methodology shown in Appendix B). Again making the assumption that the average R-value boost that is imparted to the $20 \%$ of the ducts in contact with this cellulose insulation is R-5.5, we can calculate that the operational supply duct $\mathrm{R}$-value for the $80 \%$ of ductwork that is in contact with attic air (and now with the added duct wrap) is 11.8 . The R-value for the $20 \%$ of ductwork that is in contact with attic floor insulation remains at 11.0 , as it was prior to the retrofit.

We conclude, then that addition of R-7 foil-faced batt insulation to the $80 \%$ of duct surface area that was in contact with the attic air (the $20 \%$ in contact with the attic floor insulation remained largely unaltered) increased average duct system R-value from 6.1 to 11.6 , a $90 \%$ increase in Rvalue.

Post-retrofit duct R-value summary:

- The $20 \%$ of ducts that were in contact with attic floor insulation remained essentially unchanged from the pre-retrofit status. It therefore is determined to have an effective Rvalue of 11.0 including the R-value boost that results from contact with the attic floor insulation.

- The $80 \%$ of ductwork not in contact with the attic floor insulation increased from an effective R-5.5 to 11.8 as a result of adding the nominal R-7 duct wrap.

- The overall post-retrofit attic duct system R-value, including the R-value enhancement from adding the R-7 duct wrap and from duct contact with the attic floor insulation, was determined to be 11.6.

- The overall duct system effective R-value, including all effects, increased by $92 \%$ from 6.06 to 11.62 as a result of adding the R-7 duct wrap to an estimated $80 \%$ of the existing duct system exterior surface area. 


\subsection{Experimental Configurations}

The energy and peak demand savings that result from improved duct insulation are presented in Sections 3 through 6 of this report. The pre-duct insulation retrofit data was collected during what was called the Phase 3 experiments (2-ton heat pumps with "as-found" ducts). The postduct insulation retrofit data was collected during what was called the Phase 4 experiments (2-ton heat pumps with enhanced duct R-value). All experimental configurations were carried out using the attic duct system with the 2-ton fixed-capacity SEER 13 and the 2-ton variable-capacity SEER 22 heat pumps. Data is available for both the cooling and heating seasons, though the heating season data is substantially limited, especially for the pre-retrofit period because of relatively mild winter weather.

In the Phase 3 experiments, three cooling configurations were examined using the original attic ducts, all with 2-ton heat pumps:

- SEER 13 unit with attic ducts

- SEER 22 unit with attic ducts

- SEER 22 unit with attic ducts and RH control set to $45 \%$.

In the Phase 3 experiments, two heating configurations were examined using the original attic ducts, all with 2-ton heat pumps:

- SEER 13 unit with attic ducts

- SEER 22 unit with attic ducts.

In Phase 4, a total of three experimental cooling configurations were examined using attic ducts with enhanced insulation, all with 2-ton heat pumps:

- SEER 13 unit with attic ducts

- SEER 22 unit with attic ducts.

- SEER 22 unit with attic ducts and RH control set to $45 \%$.

In Phase 4, a total of two experimental heating configurations were examined using attic ducts with enhanced insulation, all with 2-ton heat pumps:

- SEER 13 unit with attic ducts

- SEER 22 unit with attic ducts.

Note that the term SEER 22 (45\%), which will be used throughout this report, refers to cooling operation of the variable-capacity system in humidity control mode with RH control set to $45 \%$. 


\section{Indoor and Outdoor Environmental Conditions and System Run Times during the Cooling Season}

Tables 4 and 5 summarize indoor and outdoor environmental conditions, and system run time, during the pre- and post-insulation retrofit periods. The data in Table 4 is for all days in which significant cooling occurred for the pre-retrofit (May 25, 2012 through July 22, 2013) and postretrofit (July 27, 2013 through February 12, 2014) periods including a substantial number of days that would not be considered typical hot and humid summer weather.

Table 4. Average Outdoor and Indoor Temperature, Indoor RH, and Cooling System Run Time for all Days When Cooling Occurred Including Days When Outdoor Dew Point Temperature was Below $70^{\circ} \mathrm{F}$ Using 2-Ton Heat Pumps

\begin{tabular}{|c|c|c|c|c|c|c|}
\hline & \multicolumn{3}{|c|}{ Pre-retrofit } & \multicolumn{3}{|c|}{ Post-retrofit } \\
\hline & S13 & S22 & S22 (45) & S13 & S22 & S22 (45) \\
\hline $\begin{array}{l}\text { Average outdoor dry-bulb temperature } \\
\left({ }^{\circ} \mathrm{F}\right)\end{array}$ & 70.7 & 76.9 & 72.6 & 75.3 & 75.9 & 73.9 \\
\hline $\begin{array}{l}\text { Average outdoor dew point temperature } \\
\left({ }^{\circ} \mathrm{F}\right)\end{array}$ & 62.0 & 68.1 & 63.0 & 65.9 & 66.2 & 65.3 \\
\hline Average indoor temperature $\left({ }^{\circ} \mathrm{F}\right)$ & 77.4 & 76.6 & 76.3 & 76.4 & 76.2 & 75.9 \\
\hline Delta-temperature (out-in; ${ }^{\circ} \mathrm{F}$ ) & -4.1 & 0.2 & -3.9 & -1.1 & -0.3 & -2.0 \\
\hline Indoor RH & 51.1 & 55.4 & 51.7 & 50.6 & 56.1 & 53.4 \\
\hline Cooling system run time (\%) & 31.3 & 69.2 & 55.8 & 37.8 & 62.1 & 57.8 \\
\hline Number of days & 30 & 37 & 52 & 49 & 50 & 58 \\
\hline
\end{tabular}

The data in Table 5 is for all days in which cooling occurred for the pre-retrofit (May 25, 2012 through July 22, 2013) and post-retrofit (July 27, 2013 through February 12, 2014) periods, but only for days when the outdoor dew point temperature was $70^{\circ} \mathrm{F}$ or higher (in other words, for days that can be considered primarily hot and humid). 
Table 5. Average Outdoor and Indoor Temperature, Indoor RH, and Cooling System Run Time for All Days When Cooling Occurred and Outdoor Dew Point Temperature was $70^{\circ} \mathrm{F}$ or Higher, Using 2-Ton Heat Pumps

\begin{tabular}{l|c|c|c|c|c|c|}
\hline & \multicolumn{3}{|c|}{ Pre-retrofit } & \multicolumn{3}{c}{ Post-retrofit } \\
\hline & S13 & S22 & S22 (45) & S13 & S22 & S22 (45) \\
\hline $\begin{array}{l}\text { Average outdoor dry-bulb temperature } \\
\left({ }^{\circ} \mathrm{F}\right)\end{array}$ & 78.1 & 79.6 & 78.8 & 82.0 & 81.4 & 80.4 \\
\hline $\begin{array}{l}\text { Average outdoor dew point temperature } \\
\left({ }^{\circ} \mathrm{F}\right)\end{array}$ & 73.1 & 71.0 & 70.8 & 72.6 & 71.3 & 71.5 \\
\hline \begin{tabular}{l} 
Average indoor temperature ( $\left.{ }^{\circ} \mathrm{F}\right)$ \\
\hline Delta-temperature (out-in; $\left.{ }^{\circ} \mathrm{F}\right)$
\end{tabular} & 77.9 & 76.6 & 76.6 & 76.7 & 76.5 & 76.5 \\
\hline \begin{tabular}{l} 
Indoor RH \\
\hline Cooling system run time (\%)
\end{tabular} & -0.1 & 3.1 & 2.0 & 5.3 & 4.9 & 3.9 \\
\hline Number of days & 42.6 & 80.4 & 80.5 & 55.8 & 80.7 & 84.0 \\
\hline
\end{tabular}

\subsection{System Run Time and Conductive Duct Losses}

Earlier Phase 1 experiments (2009-2010) found that a 3-ton variable-capacity heat pump (SEER 21 ) operated about $94 \%$ more hours per day compared to the fixed-capacity heat pump of the same nominal capacity on a typical summer day $(70 \%$ run time versus $36 \%$ run time; Cummings and Withers 2011). The greater run time occurs because the variable-capacity system spends a large majority of its time at or near minimum capacity. The fixed-capacity system, of course, operates only at full capacity and simply cycles off when the space temperature set point has been satisfied. The variable-capacity 2 -ton system tested in these latest experiments had approximately $70 \%$ greater run time compared to the comparably sized fixed-capacity system ( $88 \%$ run time versus $52 \%$ run time for daily outdoor average temperature at $82^{\circ} \mathrm{F}$ ).

Because of the longer supply air dwell time (in the attic ducts), conductive losses are greater for variable-capacity systems. Phase 1 research (comparing fixed-capacity and variable-capacity 3ton heat pumps) identified that switching from an indoor duct system to an attic duct system caused a $13 \%$ increase in cooling energy use for the fixed-capacity system versus $21 \%$ for the variable-capacity system (essentially all of these losses were related to conduction through the duct walls since duct air leakage was less than $1 \%$ of system air flow).

Table 6 presents energy savings for the typical summer day $\left(82^{\circ} \mathrm{F}\right.$ outdoors and $77^{\circ} \mathrm{F}$ indoors $)$ for various 2-ton heat pumps, duct systems, and operation modes (RH control or not). Table 6 uses data from this current project, Phase 4 as well as the prior project Phase 3. Phase 3 research (Cummings, Withers, and Kono 2014) (comparing fixed-capacity and variable-capacity 2-ton heat pumps) identified that switching from an indoor duct system to an attic duct system caused a $14.0 \%$ increase in cooling energy use for the fixed-capacity system (calculation $=1 /(1-0.123)$ ) versus $21.7 \%$ for the variable-capacity system (calculation $=1 /(1-0.178)$ ). In each case, the 
losses associated with using the attic ducts have been determined by comparison to operation with the indoor ducts. Placing the supply ducts inside the conditioned space eliminated all of these losses.

Table 6. Energy Consumption for 2-Ton Heat Pumps for Attic Ducts Base Level R-6, and with Enhanced Duct Insulation R-11 as well as with Indoor Duct System. Results Based on Regression Analysis at $77^{\circ} \mathrm{F}$ Indoor and $82^{\circ} \mathrm{F}$ Outdoor Conditions.

\begin{tabular}{|c|c|c|c|c|c|c|c|c|}
\hline $\begin{array}{l}\text { Heat Pump } \\
\text { System }\end{array}$ & $\begin{array}{l}\text { Duct } \\
\text { R-value }\end{array}$ & $\begin{array}{c}\text { Energy } \\
\text { (kWh/d) }\end{array}$ & $\begin{array}{c}\text { Saved } \\
\text { kwh/d R6 } \\
\text { to R11 } \\
\text { attic }\end{array}$ & $\begin{array}{c}\text { \% Energy } \\
\text { Savings R6 } \\
\text { to R11 } \\
\text { Attic }\end{array}$ & $\begin{array}{c}\text { Saved } \\
\text { kwh/d R6 } \\
\text { Attic to } \\
\text { Indoor }\end{array}$ & $\begin{array}{l}\text { \% Energy } \\
\text { Savings R6 } \\
\text { Attic to } \\
\text { Indoor }\end{array}$ & $\begin{array}{l}\text { Saved } \\
\text { kwh/d } \\
\text { R11 Attic } \\
\text { to Indoor }\end{array}$ & $\begin{array}{l}\text { \% Energy } \\
\text { Savings } \\
\text { R11 Attic } \\
\text { to Indoor }\end{array}$ \\
\hline SEER 13 attic & 6 & 23.83 & & & & & & \\
\hline SEER 13 attic & 11 & 22.30 & 1.54 & $6.4 \%$ & & & & \\
\hline $\begin{array}{l}\text { SEER } 13 \\
\text { indoor }\end{array}$ & 6 & 20.89 & & & 2.94 & $12.3 \%$ & 1.41 & $6.3 \%$ \\
\hline SEER 22 attic & 6 & 16.57 & & & & & & \\
\hline SEER 22 attic & 11 & 15.42 & 1.15 & $6.9 \%$ & & & & \\
\hline $\begin{array}{l}\text { SEER } 22 \\
\text { indoor }\end{array}$ & 6 & $\mathrm{~N} / \mathrm{A}$ & & & & & & \\
\hline $\begin{array}{c}\text { SEER } 22 \\
\text { (RH45) attic }\end{array}$ & 6 & 19.71 & & & & & & \\
\hline $\begin{array}{c}\text { SEER } 22 \\
\text { (RH45) attic }\end{array}$ & 11 & 18.10 & 1.61 & $8.2 \%$ & & & & \\
\hline $\begin{array}{c}\text { SEER } 22 \\
\text { (RH45) } \\
\text { indoor }\end{array}$ & 6 & 16.2 & & & 3.51 & $17.8 \%$ & 1.90 & $10.5 \%$ \\
\hline
\end{tabular}

Given that running cold supply air through the original R-6 attic ducts generated losses on the order of $12 \%$ to $22 \%$ of total available cooling (for the 2 -ton fixed- and variable-capacity systems, respectively), it is reasonable that a thermally improved duct system would yield reduced losses and improved system operating efficiency. Furthermore, it is also reasonable that increased duct R-values would disproportionately improve the performance of variable-capacity systems because those systems produce longer dwell time of conditioned air within the ducts. And in fact that is the case. Savings from using the indoor ducts (compared to using the attic ducts) are $45 \%$ greater for the variable-capacity system compared to the fixed-capacity system (calculation: $(17.8 \%-12.3 \%) / 12.3 \%$ x $100=44.7 \%)$.

These percentages are relative to the higher and lower loads of the fixed and variable-capacity systems respectively. This is a way of isolating the dwell air effect, but does not give a sense of the absolute magnitude and importance of the effect. Observing the ( $\mathrm{kwh} /$ day) columns in Table 
6 and normalizing the percentage calculations to the cooling energy used by the SEER 13 fixedcapacity unit with R6 ducts in the attic, we see that the absolute effect of dwell air for fixed versus variable-capacity equipment ranges from about $2.4 \%$ to $-1.6 \%(0.57$ to $-0.39 \mathrm{kwh} / \mathrm{day})$. In one case the effect is reversed and adding insulation to the SEER 13 system actually saved more energy than adding insulation to the SEER 22 system. For example in Table 6, in the column labeled "Saved kwh/day R6 Attic to Indoor" the SEER 22 (RH45) system saves $3.51 \mathrm{kwh} /$ day and the SEER 13 saves $2.94 \mathrm{kwh} /$ day. The disproportionately greater dwell air effect for the SEER 22 system is $3.51-2.94=0.57 \mathrm{kwh} /$ day. $0.57 / 23.83 \times 100=2.4 \%$. This is the maximum dwell air effect observed from Table 6 . Assuming a cost of electricity of $\$ 0.15 / \mathrm{kwh}$ and an 8 month (24 hour/day) cooling season, the difference in "dwell air" effect between the variable and fixed-capacity systems amounts to a maximum of about $\$ 20 /$ year. The savings going from a SEER 13 to a SEER 22 apparatus is much greater (4.9 to $7.3 \mathrm{kwh} /$ day) $(20 \%$ to $30 \%)$, and the next greatest effect is going from an R6 duct in the attic to an R6 duct within the conditioned space (2.94 to $3.51 \mathrm{kwh} /$ day) (12\% to $15 \%)$.

The primary research questions to be answered by these experiments are: 1) "How much improvement in system seasonal energy efficiency occurs when duct insulation R-value is increased (from about 6 to 11), for the fixed-capacity and variable-capacity systems?" and 2) "How much reduction in peak demand results when duct insulation R-values are increased (from about 6 to 11), for the fixed-capacity and variable-capacity systems?" Before addressing these two questions in Section 4, a discussion of RH impacts of the tested systems is presented.

\subsection{Indoor Humidity Control}

It is believed by some in the building science community that standard direct-expansion (DX) cooling systems do not effectively control indoor RH. Data presented in Tables 4 and 5, which summarize data for the full cooling season and for hot and humid weather only, respectively, suggest otherwise. Table 5 (for hot and humid weather), for example, shows that the 2-ton SEER 13 fixed-capacity system produced indoor RH that for combined pre- and post-insulation retrofit periods averaged just below 50\%. Data in Table 4 (that includes many days with lower dry-bulb and dew point temperatures) show that the same 2-ton SEER 13 fixed-capacity system produced indoor RH that, for combined pre- and post-insulation retrofit periods, averaged just below 51\%.

Interestingly, indoor RH control was even better during earlier (Phase 1) experiments when 3-ton fixed-capacity and variable-capacity systems were in use. Data in Table 7 (for hot and humid weather periods for Phase 1; source Cummings and Withers 2011) shows that the 3-ton SEER 13 fixed-capacity system produced indoor RH that, for operation with attic and indoor ductwork, averaged just above $47 \%$. 
Table 7. Average Outdoor and Indoor Temperature, Indoor RH, and Cooling System Run Time for Days When Outdoor Dew Point Temperature was $70^{\circ} \mathrm{F}$ or Higher during May 1, 2010, through October 28, 2010, for Phase 1 Using 3-Ton Heat Pumps. The Data Has Been Screened So That the Phase 1 and Phase 3 Data Sets Have Comparable Outdoor Temperatures.

\begin{tabular}{|c|c|c|c|c|c|c|}
\hline & $\begin{array}{l}\text { S13 } \\
\text { Attic }\end{array}$ & $\begin{array}{l}\text { S21 } \\
\text { Attic }\end{array}$ & $\begin{array}{c}\text { S21 } \\
\text { (RH45) } \\
\text { Attic }\end{array}$ & $\begin{array}{l}\text { S13 } \\
\text { Indoor }\end{array}$ & $\begin{array}{l}\text { S21 } \\
\text { Indoor }\end{array}$ & $\begin{array}{c}\text { S21 } \\
\text { (RH45) } \\
\text { Indoor }\end{array}$ \\
\hline $\begin{array}{l}\text { Average outdoor dry-bulb } \\
\text { temperature }\left({ }^{\circ} \mathrm{F}\right)\end{array}$ & 80.7 & 80.5 & 81.0 & 83.1 & 81.3 & 81.3 \\
\hline $\begin{array}{l}\text { Average outdoor dew point } \\
\text { temperature }\left({ }^{\circ} \mathrm{F}\right)\end{array}$ & 72.2 & 71.9 & 71.5 & 73.1 & 71.9 & 72.1 \\
\hline Average indoor temperature $\left({ }^{\circ} \mathrm{F}\right)$ & 77.1 & 76.5 & 77.1 & 77.8 & 76.6 & 76.6 \\
\hline Delta-temperature (out-in; ${ }^{\circ} \mathrm{F}$ ) & 3.2 & 3.5 & 3.6 & 5.1 & 4.1 & 4.0 \\
\hline Indoor RH & 46.7 & 50.5 & 48.1 & 47.7 & 52.6 & 51.1 \\
\hline Cooling system run time (\%) & $35.0 \%$ & $65.4 \%$ & $67.5 \%$ & $33.7 \%$ & $60.2 \%$ & $64.7 \%$ \\
\hline
\end{tabular}

It is also of interest to note that this 3-ton fixed-capacity system, which was oversized by $60-90 \%$ (depending on which duct system was in use), achieved lower indoor RH than the "right-sized" (2-ton) fixed-capacity system (about $47 \%$ for the 3 -ton and $50.5 \%$ for the 2 -ton). This data presents a strong challenge to two beliefs: 1) that DX systems do not effectively control indoor $\mathrm{RH}$ during hot and humid weather and 2) that oversizing of DX systems yields poor indoor $\mathrm{RH}$ control.

Note that while the lab house had no mechanically-induced ventilation during the current Phase 3 and 4 experiments (or during the earlier Phase 1 experiments with the 3-ton heat pumps), the $\mathrm{MH}$ Lab had a very leaky envelope with an ACH50 of 10.2 and an estimated average natural air infiltration rate of 0.26 ach or $58 \mathrm{cfm}$, which is only slightly lower than the current American Society of Heating, Refrigerating and Air-Conditioning Engineers (ASHRAE) Standard 62.2 recommended ventilation rate.

Some in the building science community also believe that variable-capacity systems cannot provide effective indoor RH control. Data presented in Tables 4 and 5 indicate that this belief may not be warranted. Table 5 (for hot and humid weather), for example, shows that the 2-ton SEER 22 variable-capacity system produced indoor $\mathrm{RH}$ that for pre- and post-insulation retrofit periods averaged about 55\% (note that all of the indoor $\mathrm{RH}$ values specified in this section are an average for the entire day and for days with $\mathrm{T}_{\text {ambient,dp }}>70^{\circ} \mathrm{F}$ ). While $55 \%$ indoor $\mathrm{RH}$ is somewhat elevated relative to a desired target, when the system was placed into RH control mode (with $45 \%$ set point), average indoor $\mathrm{RH}$ declined to about $51.5 \%$.

Additional insight into RH control is obtained by looking at earlier Phase 2 results, when 3-ton fixed-capacity and variable-capacity systems were tested with substantial duct leaks $(8 \%$ return leakage (RL), 8\% supply leakage (SL), and combined 8\% RL and SL (Cummings and Withers 
2013). When the mechanically-induced duct leaks were added to the natural infiltration, the daily average air exchange between indoors and outdoors was about 0.4 ach or $90 \mathrm{cfm}$. While not meeting all aspects of the ASHRAE 62.2 ventilation requirements, this infiltration rate is actually greater on the average summer day than the Standard 62.2 requirements, and therefore useful for assessing indoor RH control. The Phase 2 results found that the oversized, fixed-capacity 3-ton system produced about $50 \%$ RH with the various duct leaks in operation.

With a variety of duct leaks in operation, the variable-capacity SEER 21 3-ton system in normal control mode produced an average of $55 \% \mathrm{RH}$, which can be considered a marginal level of humidity control. However, when operated in RH control mode (45\% set point), the unit produced 52\% RH with either supply leaks or return leaks operating, averaged over the entire day. Furthermore, the authors examined the Nordyne system's RH control operation and concluded that substantial improvement in RH control could be achieved with modest alterations in $\mathrm{cfm} /$ ton relationships and with limited impact on system operating efficiency.

Summary of indoor RH results:

- The 2-ton and 3-ton fixed-capacity systems discussed in this report provide excellent indoor RH control throughout the long cooling season in central Florida.

- When duct leaks of $8 \%$ system air flow operate, the oversized fixed-capacity systems continue to provide very adequate indoor RH (about 50\%).

- The 2- and 3-ton variable-capacity systems tested in these experiments produced average indoor RH in the range of 55\% and 51.5, respectively, when in standard control mode. When set to RH control mode with $45 \%$ set point, average indoor RH was $52 \%$ and $49.6 \%$ for the 2-ton and 3-ton units, respectively.

- Even when 8\% duct leaks were introduced, the substantially oversized 3-ton system produced seasonal average indoor RH of $52 \%$. 


\section{Seasonal Cooling Energy Impacts of Duct R-value}

Nominal R-7 duct wrap was added to the existing attic duct system in the MH Lab in the third week of July 2013. Based on results reported in Section 2.4 of this document, overall effective duct R-value for the duct system as operated increased from 6.1 to 11.6. Analysis has been performed to characterize the relative cooling energy consumption $(\mathrm{kWh} / \mathrm{day})$ versus delta- $\mathrm{T}$ ( $\left.\mathrm{T}_{\text {ambient }}-\mathrm{T}_{\text {indoors }}\right)$ of the 2-ton SEER 13 and SEER 22 units for the periods before and after the duct insulation upgrade. Various plots and tables are presented in this section to compare daily cooling energy use versus daily average delta-T for a total of 6 space-cooling test configurations. A least-squares, best-fit regression analysis was used to characterize daily cooling energy as a function of outdoor air minus indoor air temperature (delta-T). Figure 13 shows daily cooling energy use versus average daily delta-T for all six test configurations along with the resulting least-squares, second order polynomial best-fit lines. Also shown in Figure 13 are the best-fit polynomial equations and coefficient of determination $r^{2}$. Table 8 presents the same results in tabular form: cooling energy consumption of the fixed- and variable-capacity heat pumps for before and after the duct insulation upgrade including absolute and percent savings with indoors at $77^{\circ} \mathrm{F}$ and outdoors at $82^{\circ} \mathrm{F}$ (a typical summer day). 


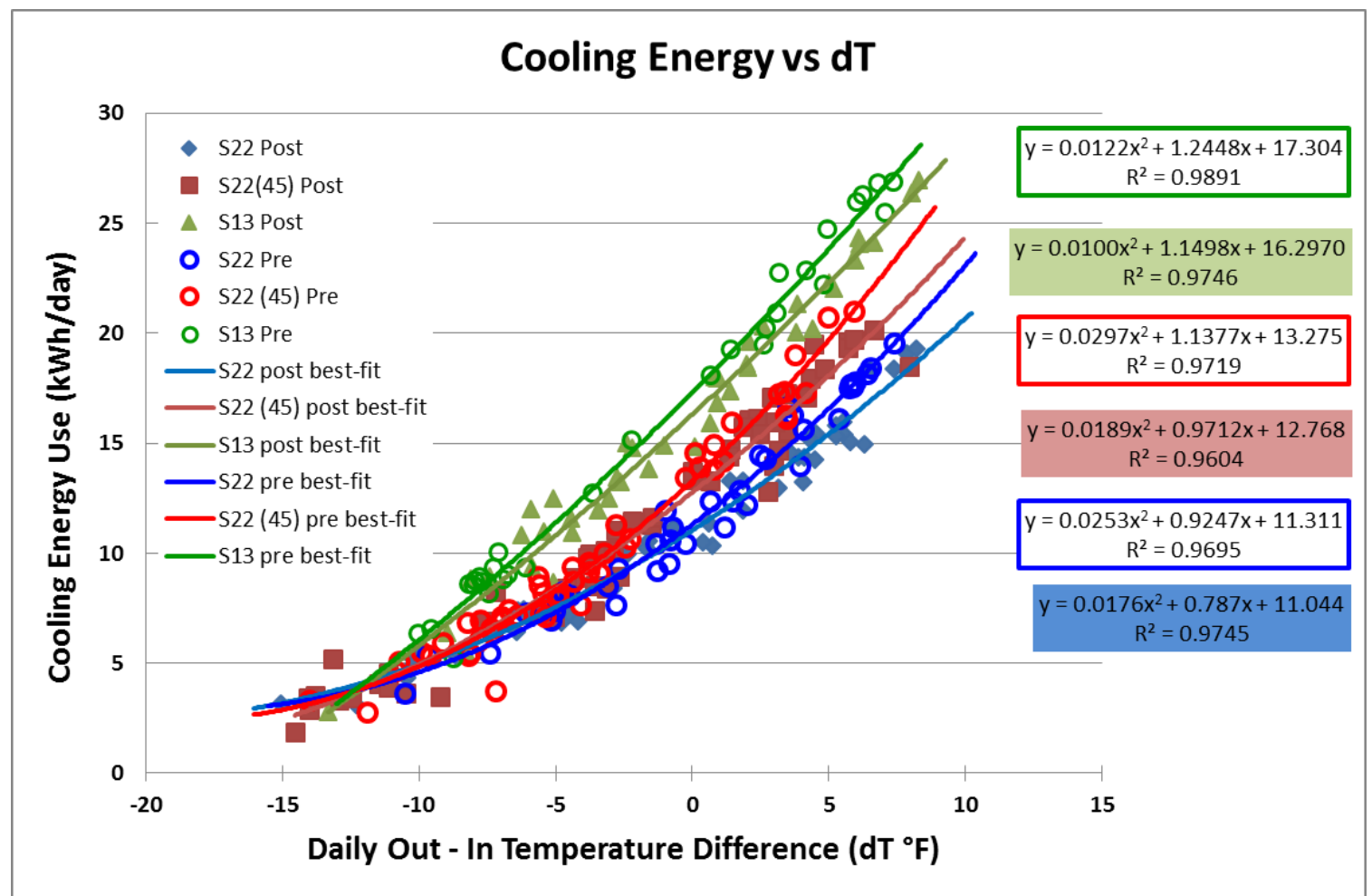

Figure 13. Cooling energy use as a function of delta-T (outdoor minus indoor temperature) for the 2-ton SEER 13 and SEER 22 heat pumps before and after duct insulation enhancement

Table 8. Regression Analysis Results and Energy Consumption for 2-Ton Heat Pumps (SEER 13 and SEER 22 Units) with "As Found" (R-6.1) and with Enhanced (R-11.6) Duct Insulation (with and without RH Control Activated for the iQ Drive System) for $5^{\circ} \mathrm{F}$ Delta-T, Which Represents a Typical Summer Day $\left(77^{\circ}\right.$ Indoors and $82^{\circ}$ Outdoors)

\begin{tabular}{c|c|c|c|c|c|c|c|c}
\hline $\begin{array}{c}\text { Heat Pump } \\
\text { System }\end{array}$ & $\begin{array}{c}\text { Duct } \\
\mathbf{R}- \\
\text { Value }\end{array}$ & $\mathbf{r}^{2}$ & $\mathbf{x}^{2}$ & $\mathbf{x}$ & Intercept & $\begin{array}{c}\text { Energy Use } \\
\text { at 5 }{ }^{\circ} \text { Delta- } \\
\mathbf{T}(\mathbf{k W h} / \mathbf{d})\end{array}$ & $\begin{array}{c}\text { \% Energy } \\
\text { Saved } \\
\mathbf{k w h} / \mathbf{d}\end{array}$ & $\begin{array}{c}\text { Suvings from } \\
\text { Duct Insulation } \\
\text { Upgrade }\end{array}$ \\
\hline SEER 13 & 6 & 0.99 & 0.0122 & 1.2448 & 17.304 & 23.83 & & \\
\hline SEER 13 & 11 & 0.97 & 0.0100 & 1.1498 & 16.297 & 22.30 & 1.54 & $6.4 \%$ \\
\hline SEER 22 & 6 & 0.97 & 0.0253 & 0.9247 & 11.311 & 16.57 & & \\
\hline SEER 22 & 11 & 0.97 & 0.0176 & 0.7870 & 11.044 & 15.42 & 1.15 & $6.9 \%$ \\
\hline SEER 22 (RH45) & 6 & 0.97 & 0.0297 & 1.1377 & 13.275 & 19.71 & & \\
\hline SEER 22 (RH45) & 11 & 0.96 & 0.0189 & 0.9712 & 12.768 & 18.10 & 1.61 & $8.2 \%$ \\
\hline
\end{tabular}

The following three figures (Figures 14 through 16) present the same cooling energy plots contained in Figure 13, but compare each individual system and configuration for pre- and postduct insulation enhancement. 


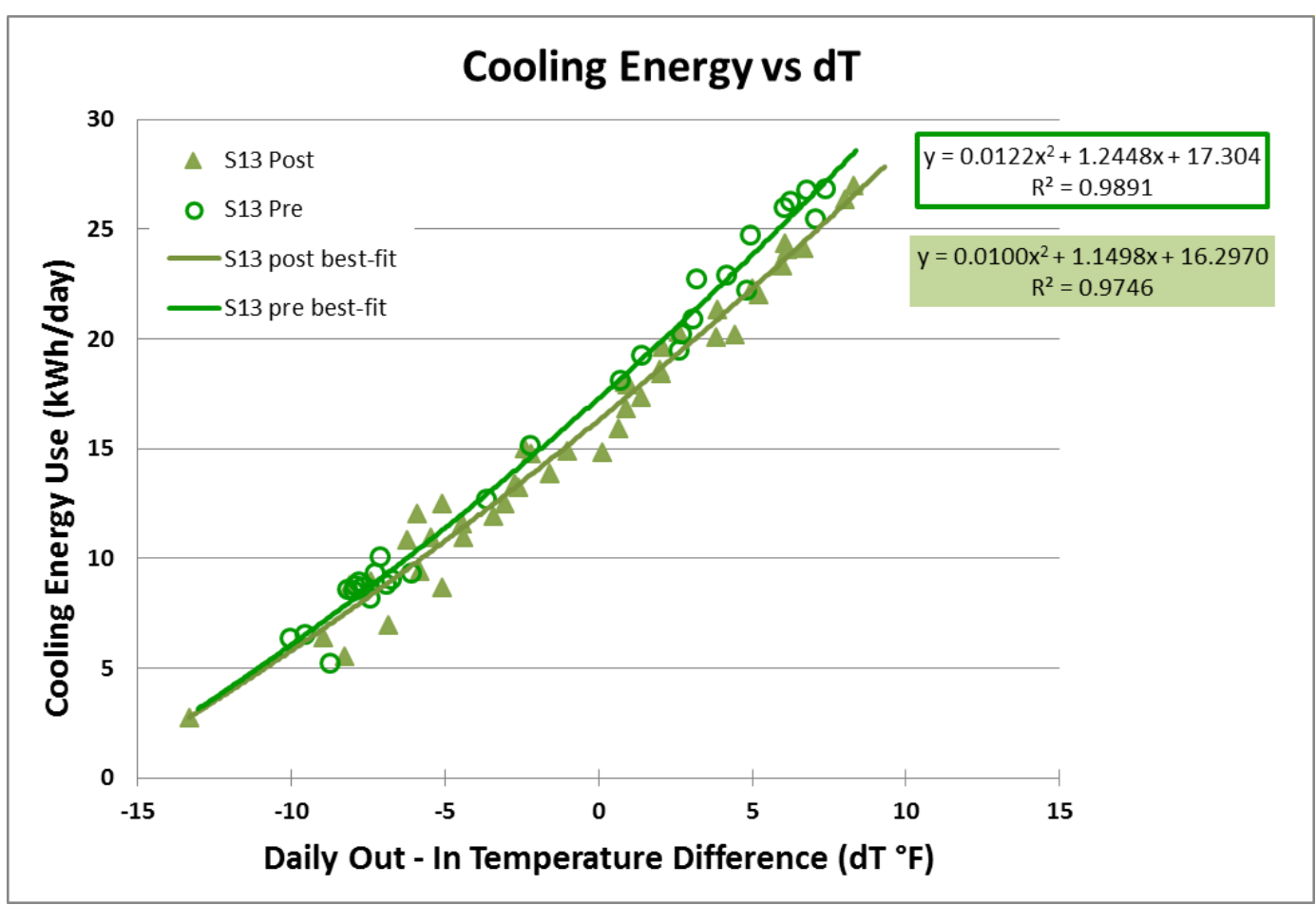

Figure 14. Cooling energy use as a function of delta-T for the 2-ton SEER 13 heat pump before and after duct insulation enhancement

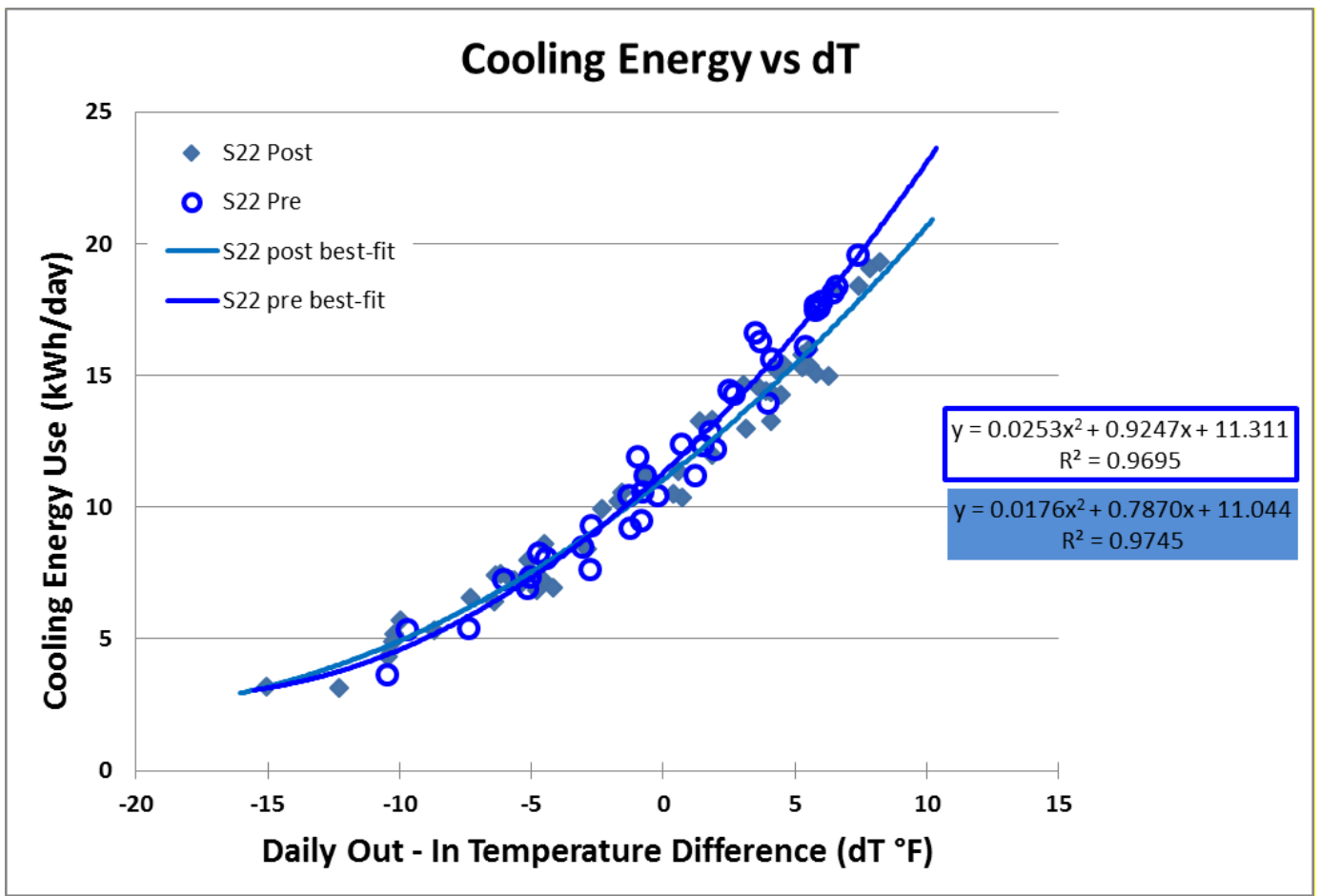

Figure 15. Cooling energy use as a function of delta-T for the 2-ton SEER 22 heat pump in standard control mode (RH control not activated) before and after duct insulation enhancement 


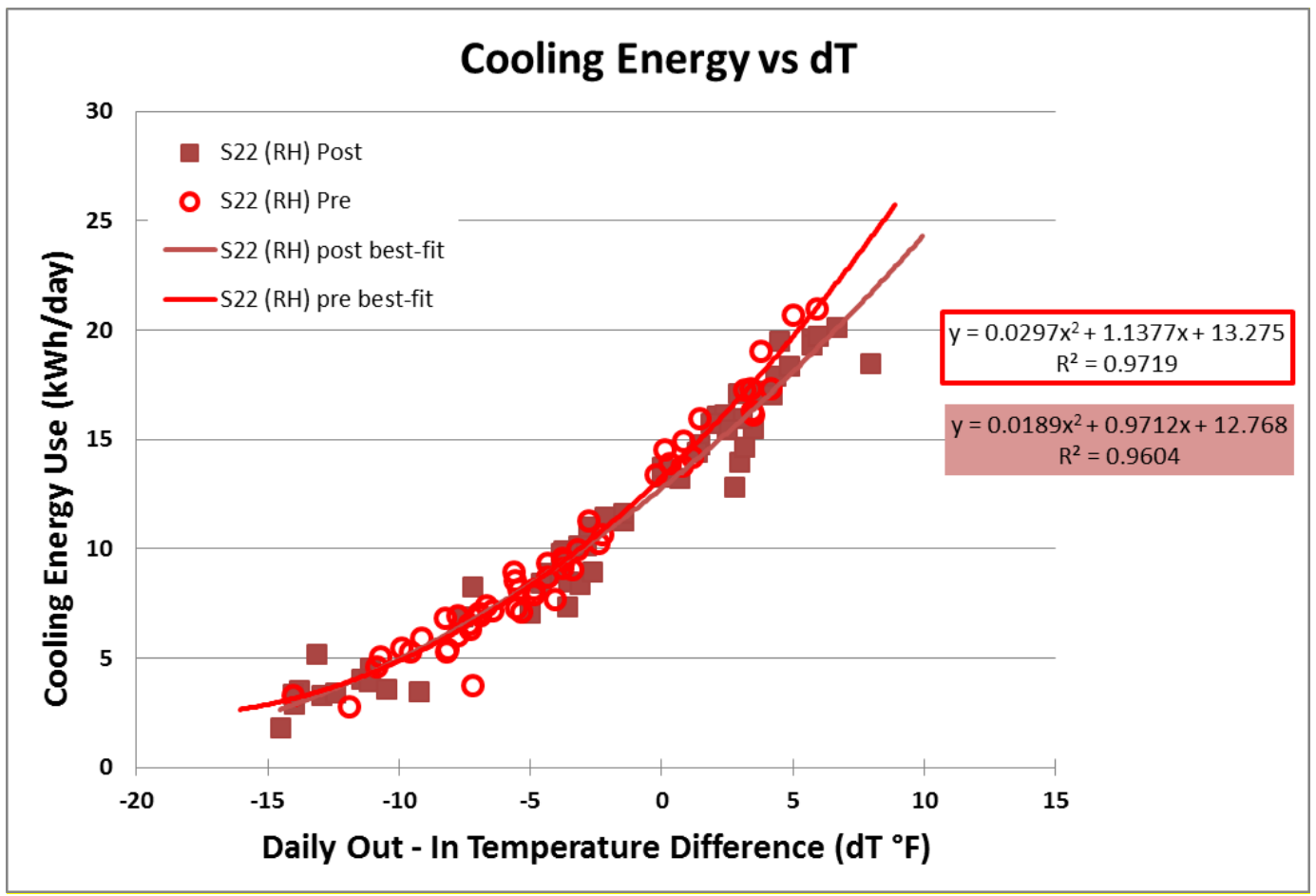

Figure 16. Cooling energy use as a function of delta-T for the 2-ton SEER 22 heat pump with RH control activated at $45 \%$ before and after duct insulation enhancement

It was, of course, expected that cooling energy savings would result from the addition of duct insulation to the existing attic duct system in the MH Lab. In fact, cooling energy savings were found for each of the three before and after comparisons (SEER 13 pre and post, SEER 22 pre and post, and SEER 22 (RH45) pre and post). On average, cooling energy savings for a typical summer day, with $82^{\circ} \mathrm{F}$ outdoors and $77^{\circ} \mathrm{F}$ indoors, was $7.2 \%$.

It was also expected that cooling energy savings from improving the duct system R-value would be greater for the SEER 22 system compared to the SEER 13 system. The reason for this expectation relates to substantially greater run time (and cold air dwell time in the ducts) for the SEER 22 system compared to the SEER 13 system. And in fact, cooling energy savings for the typical summer day were higher (on a percent basis) for the variable-capacity system compared to the fixed-capacity system. Table 8 shows that savings were $6.4 \%$ for the fixed-capacity system while the savings were $7.5 \%$, on average, for the two operational configurations (standard and RH control) for the SEER 22 system. Earlier work (Cummings, Withers, and Kono 2014) compared the energy impact of moving attic ducts into the interior conditioned space and the results reinforce the basis for more savings for variable- capacity systems compared to fixedcapacity. Moving duct from the attic to indoors is the best-case for eliminating attic conductive load compared to minimizing conductive loads by adding more duct insulation to attic ducts. Duct leakage was not a factor in this specific evaluation as the attic duct leakage was less than $1 \%$ of system total flow. Moving attic ducts into conditioned space showed a similar savings trend where savings were higher for SEER22 variable-capacity system vs the SEER 13 fixedcapacity. These results were shown earlier in Table 6 where R6 ducts moved from attic to indoor had $12.3 \%$ savings for SEER13 and 17.8\% savings for SEER22. The savings drop if attic ducts have R11 and are changed to R6 indoor duct to 6.3\% SEER 13 and 10.5\% SEER 22. 
These percentages are relative to the higher and lower loads of the fixed and variable-capacity systems respectively. This is a way of isolating the dwell air effect, but does not give a sense of the absolute magnitude and importance of the effect. Observing the (kwh/day) columns in Table 6 and normalizing the percentage calculations to the cooling energy used by the SEER 13 fixedcapacity unit with R6 ducts in the attic, we see that the absolute effect of dwell air for fixedversus variable-capacity equipment ranges from about $2.4 \%$ to $-1.6 \%(0.57$ to $-0.39 \mathrm{kwh} / \mathrm{d})$. In one case the effect is reversed and adding insulation to the SEER 13 system actually saved more energy than adding insulation to the SEER 22 system. For example in Table 6, in the column labeled "Saved kwh/d R6 Attic to Indoor" the SEER 22 (RH45) system saves $3.51 \mathrm{kwh} /$ day and the SEER 13 saves $2.94 \mathrm{kwh} /$ day. The disproportionately greater dwell air effect for the SEER 22 system is $3.51-2.94=0.57 \mathrm{kwh} /$ day. $0.57 / 23.83 \times 100=2.4 \%$. This is the maximum effect observed from Table 6 . Assuming a cost of electricity of $\$ 0.15 / \mathrm{kwh}$ and an 8 month (24 hour/day) cooling season, the difference in "dwell air" effect between the variable and fixedcapacity systems amounts to a maximum of about \$20/year. The savings going from a SEER 13 to a SEER 22 apparatus is much greater (4.9 to $7.3 \mathrm{kwh} /$ day) (20\% to $30 \%)$, and the next greatest effect is going from an R6 duct in the attic to an R6 duct within the conditioned space (2.94 to $3.51 \mathrm{kwh} /$ day) (12\% to $15 \%)$. 


\section{Impacts of Increased Duct R-value on Peak Cooling}

Analysis has been performed to identify peak cooling demand that occurred before and after the attic duct insulation upgrade from R-6.1 to R-11.6. Regression analysis has been employed to determine peak electrical demand as a function of duct system R-value. Monitored hourly cooling energy use from the hours of 2 PM to 7 PM from a group of six or more hotter-thanaverage available summer days were selected for each of the experimental configurations. Cooling energy consumption for each of the selected hours has been plotted versus the outdoorminus-indoor temperature differential for that hour. Figures 17-19 show the regression analysis results for SEER 13, SEER 22, and SEER 22 (RH45\%), respectively.

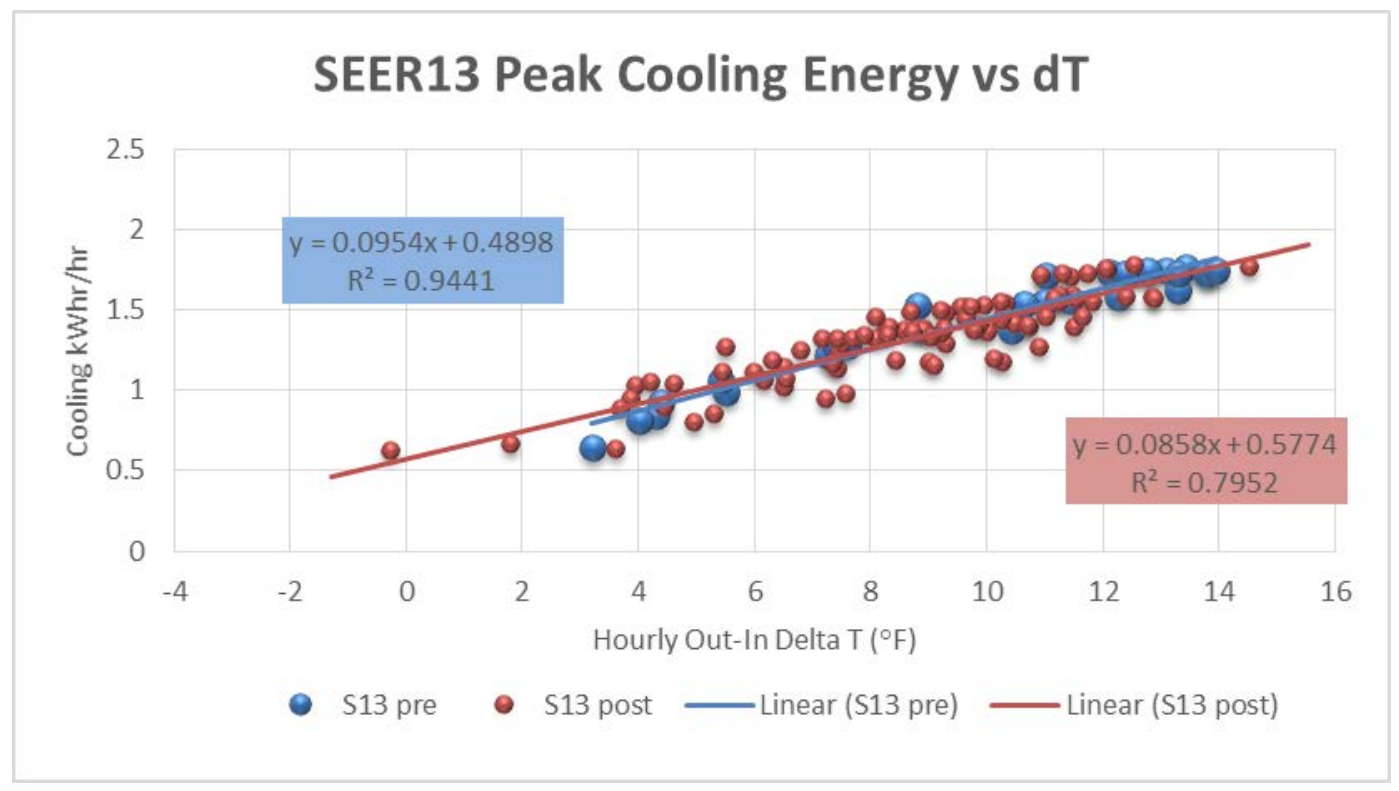

Figure 17. Least-squares regression analysis for 2 to 7 PM hourly data from hot summer days for pre- and post-duct insulation upgrade for the SEER 13 system 


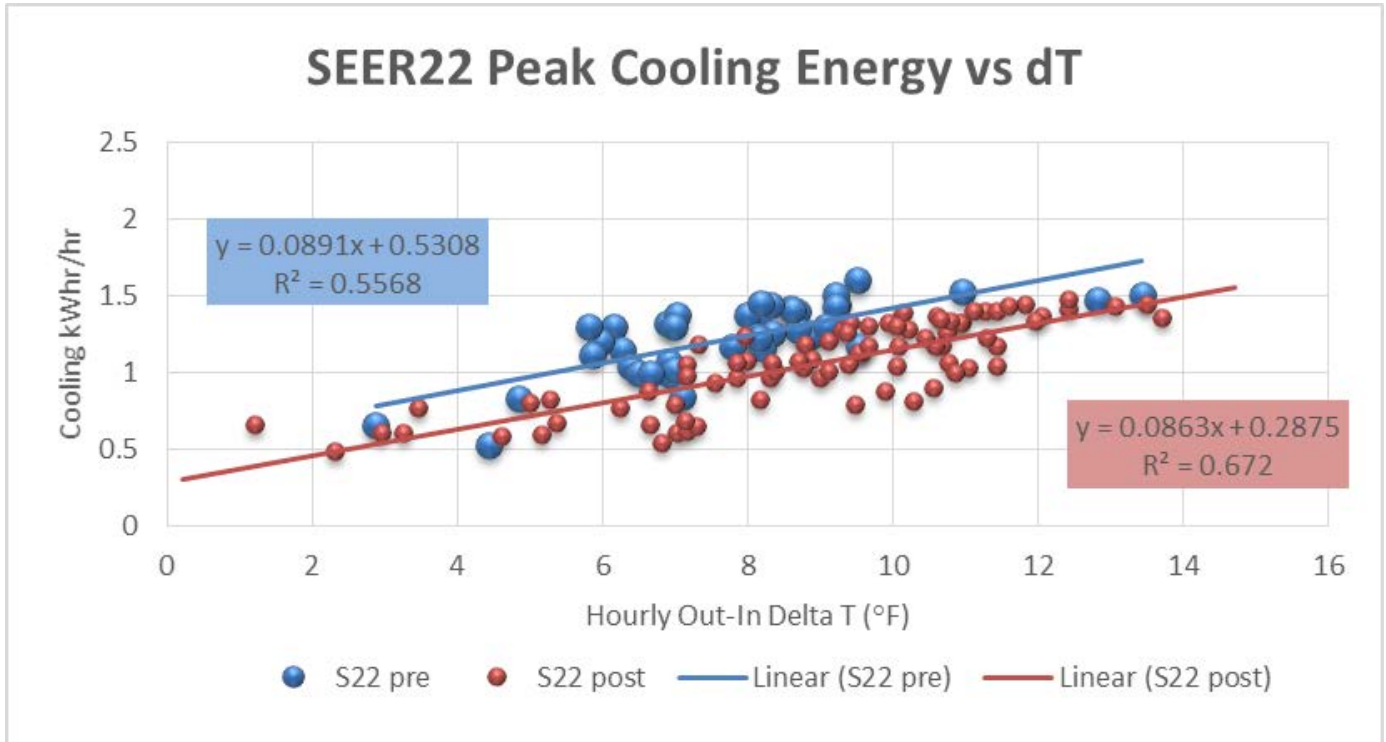

Figure 18. Least-squares regression analysis for 2 to 7 PM hourly data from hot summer days for pre- and post-duct insulation upgrade for the SEER 22 system in standard control mode

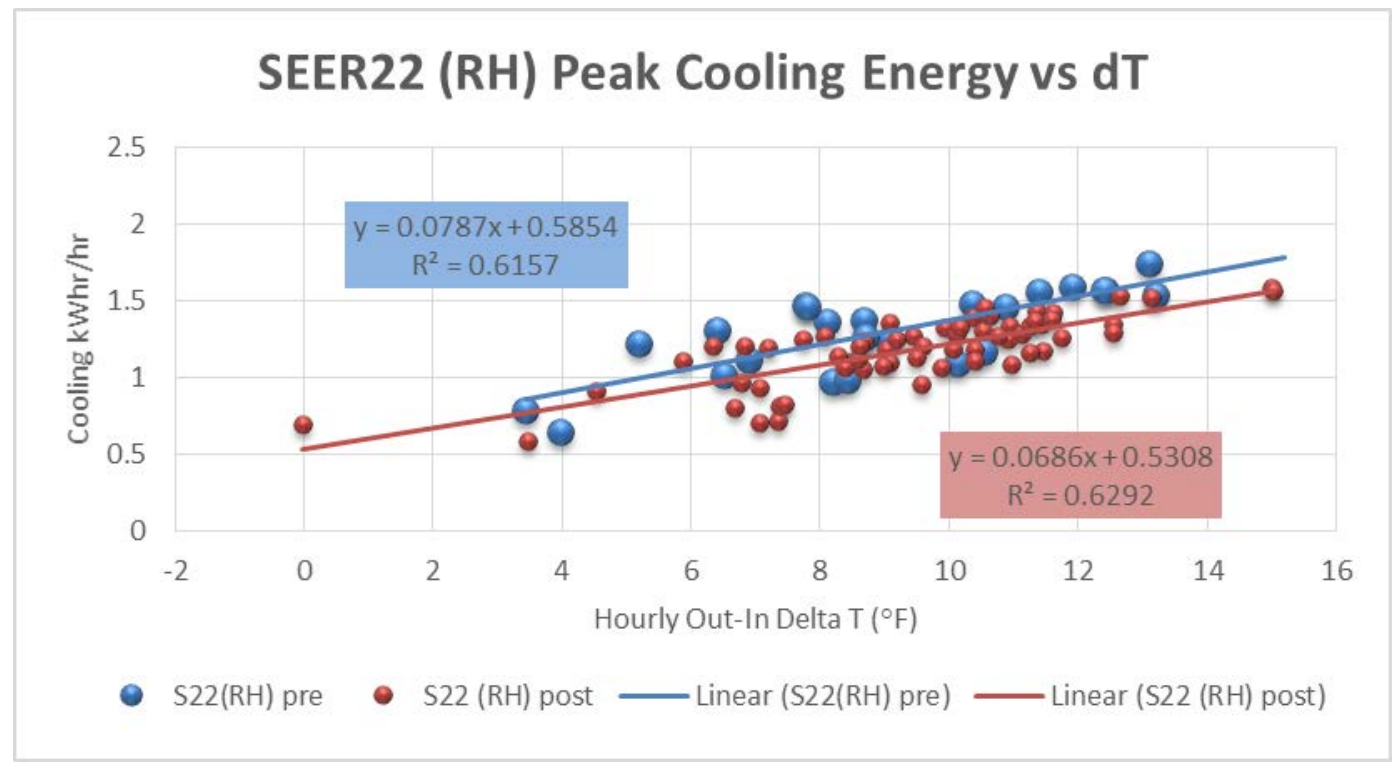

Figure 19. Least-squares regression analysis for 2 to 7 PM hourly data from hot summer days for pre- and post-duct insulation upgrade for the SEER 22 system with $45 \%$ RH control activated

\subsection{Discussion of Duct Insulation Impacts on Peak Cooling Demand}

Table 9 summarizes the regression analysis illustrated in Figures 17-19 and also shows cooling peak demand reduction resulting from duct insulation enhancement. Peak demand reductions resulting from the improved duct insulation R-values were found to be $56 \mathrm{~W}(2.9 \%), 285 \mathrm{~W}$ (15.3\%), and $206 \mathrm{~W}(11.7 \%)$ for the SEER 13, SEER 22, and SEER 22 (45\%) system configurations, respectively, for 15 degrees delta- $\mathrm{T}\left(\mathrm{T}_{\text {ambient }}-\mathrm{T}_{\text {indoors }}\right)$. On average, peak demand reduction was $182 \mathrm{~W}(9.3 \%)$ for the three test configurations. These percentages are relative to the higher and lower loads of the fixed and variable-capacity systems respectively. This is a way of isolating the dwell air effect, but does not give a sense of the absolute magnitude and 
importance of the effect. Observing the fourth row in Table 9 and normalizing the percentage savings calculations to the SEER 13 base case energy usage at $92^{\circ} \mathrm{F}$, the absolute effect of dwell air for the variable-capacity unit relative to the fixed-capacity unit ranges from $11.9 \%$ to $7.8 \%$. This indicates more importance for the dwell air effect at peak operating conditions than for the seasonal analysis however, this result is uncertain as explained below.

The statistical P-values indicate the tests to be statistically significant, however, there is a relatively high amount of uncertainty associated with the indicated savings. The standard error of all pre/post comparisons averaged $137 \mathrm{~W}$ or about $75 \%$ of the predicted average peak cooling savings of $182 \mathrm{~W}$. The SEER13 system having lowest savings of $56 \mathrm{~W}$ had a standard error of about $100 \mathrm{~W}$ which is 1.8 times the predicted savings. Given the high level of uncertainty relative to the savings, the SEER 13 savings results are not statistically significant. Further discussion on the limit in SEER 13 savings is discussed following Table 9.

The uncertainty of all peak cooling evaluations could be reduced significantly by having more data available where composite pre and post days having very similar outdoor peak conditions from which more reliable comparisons can be made. There were too few days with comparable hot weather from which these type of comparisons could be made. It is for this reason, the linear regression least squares best-fit analysis method above was chosen.

Table 9. Peak Demand Best-Fit Equation and Coefficients in the Form of $Y=A+B(X)$, for Pre- and Post-duct Wrap for Three System Configurations, Where $Y$ is the Peak Hour Cooling Electrical Energy Use and $X$ is Delta-T $\left(X=15^{\circ} \mathrm{F}\right.$ for This Example; $92^{\circ} \mathrm{F}$ Outdoors and $77^{\circ}$ Indoors)

\begin{tabular}{|c|c|c|c|c|c|c|}
\hline & $\begin{array}{c}\text { SEER } \\
13 \\
\text { Pre- }\end{array}$ & $\begin{array}{c}\text { SEER } \\
13 \\
\text { Post- }\end{array}$ & $\begin{array}{c}\text { SEER } \\
22 \\
\text { Pre- }\end{array}$ & $\begin{array}{c}\text { SEER } \\
22 \\
\text { Post- }\end{array}$ & $\begin{array}{c}\text { SEER } 22 \\
\text { (RH45) } \\
\text { Pre- }\end{array}$ & $\begin{array}{c}\text { SEER } \\
22 \\
\text { (RH45) } \\
\text { Post- }\end{array}$ \\
\hline (A) kW & 0.4898 & 0.5774 & 0.5308 & 0.2875 & 0.5854 & 0.5308 \\
\hline (B) $k W-{ }^{\circ} \mathrm{F}$ & 0.0954 & 0.0858 & 0.0891 & 0.0863 & 0.0787 & 0.0686 \\
\hline (Y) kW @ 92 F (delta-T = 15 F) & 1.9208 & 1.8644 & 1.8673 & 1.5820 & 1.7659 & 1.5598 \\
\hline Savings post- versus pre-retrofit $(\mathrm{kW})$ & & 0.0564 & & 0.2853 & & 0.2061 \\
\hline Savings post- versus pre-retrofit (\%) & & $2.9 \%$ & & $15.3 \%$ & & $11.7 \%$ \\
\hline
\end{tabular}

System run time for the variable-capacity SEER 22 system, whether in standard or RH control mode, was always $100 \%$ for the peak hours examined. For the SEER 13 system, run time was at or near $100 \%$ during all peak hours when delta- $\mathrm{T}>9^{\circ} \mathrm{F}$.

It appears the 2-ton SEER 13 fixed-capacity system was just meeting the load or had insufficient capacity to meet the cooling load for most hours when delta-T was $9^{\circ} \mathrm{F}$ and higher (that is, for hours when $\mathrm{T}_{\text {ambient }}$ was $86^{\circ} \mathrm{F}$ and warmer). The relevance is that the measured peak energy reduction may be greater than the analysis indicates if the pre period peak energy was limited by capacity during peak cooling hours. Because the SEER 13 appears to have been under capacity for only a few hours on just a few days, the seasonal energy impacts discussed earlier are not 
expected to be affected significantly. This is because when the system did not meet the peak load, average interior temperatures rose a few tenths of degrees higher than normal, thereby spreading the load out into later periods when the system could remove the previous stored load as well as current load all within the same day.

The impact on operating at or just under actual cooling load can be seen in Figure 20, which is the same as Figure 17, except that the red post-retrofit data points have been removed. As shown, a series of blue pre-repair dots are lined up in a horizontal fashion, for delta- $\mathrm{T} \sim 8^{\circ} \mathrm{F}$ and higher. The yellow line marks the points when the 2-ton fixed-capacity heat pump was operating 100\% of the time and drawing about $1700 \mathrm{~W}$. The other data points in line with the yellow line, but at $\mathrm{dT}<11^{\circ} \mathrm{F}$, are data from two very hot days where the system ran for nearly $100 \%$ of the hour. These points are also during the latter part of the day between $6 \mathrm{pm}-7 \mathrm{pm}$ when the outdoor temperature is dropping, but there is a carry-over of heat load stored in the building from the earlier part of day.

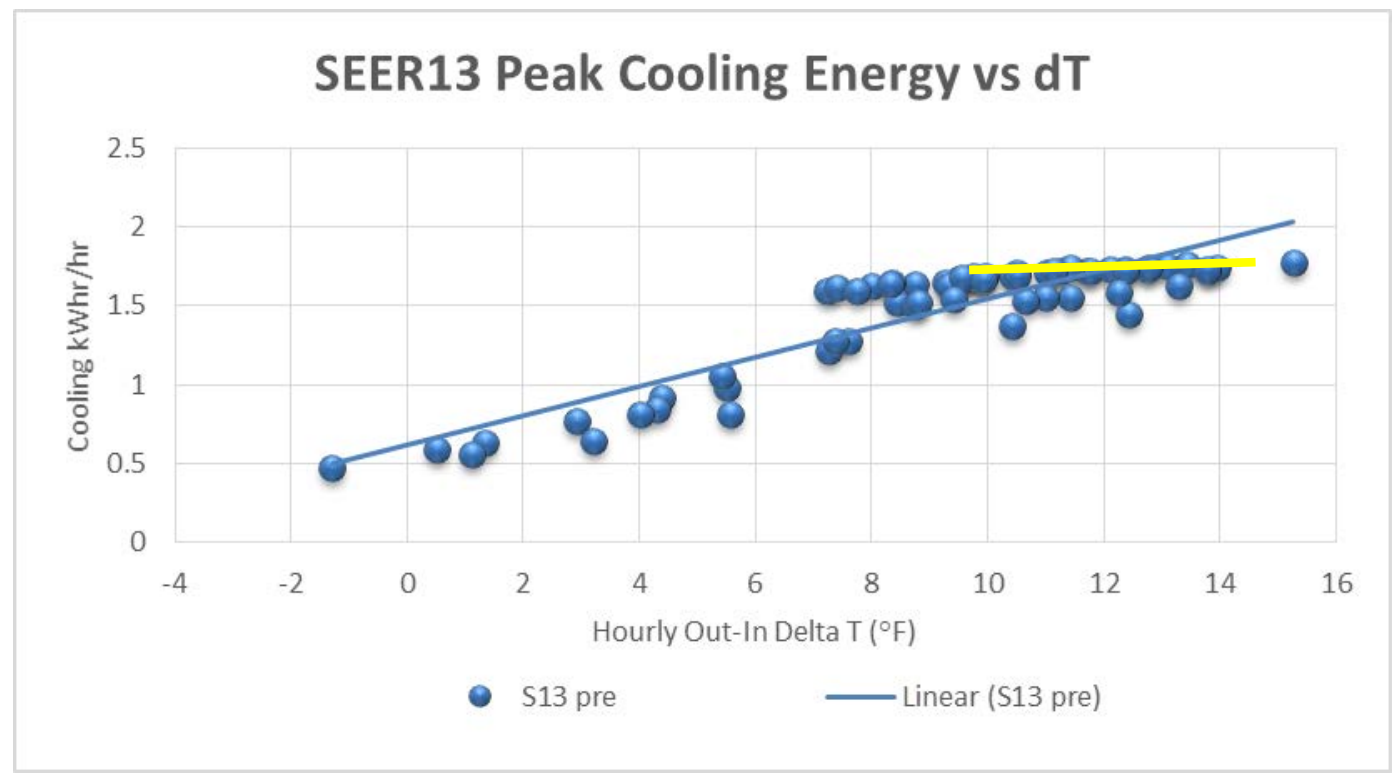

Figure 20. Least-squares regression analysis for 2 to 7 PM hourly data from hot summer days for pre-duct insulation upgrade for the SEER 13 system. Yellow line is for data at $100 \%$ run time.

There is further evidence that the SEER13 2-ton system was not able to keep up with the peak cooling load for a few hours on two of the hottest days before the ducts had insulation added. This can be seen in Figure 21, which shows interior and exterior temperatures along with run time for four consecutive days. The interior temperatures shown are from a single temperature taken at the thermostat and also from an average taken from 5 locations inside the house lab. The two days in the middle of Figure 21 are the hottest days where a noticeable rise occurs in the interior temperatures, particularly at the thermostat location. There is a distinct difference between the two outside temperatures shown. The out temperature, or "Out T", is the hourly average ambient temperature used in the delta- $\mathrm{T}$ plots, whereas the "T into cond." temperature is the run time-averaged outside air temperature drawn into the outside condenser. These outside measurements occur from two different sensors nearby each other, but at different locations. The condenser inlet air temperature is equal to or greater than the local design temperature for a couple of hours on some days. 

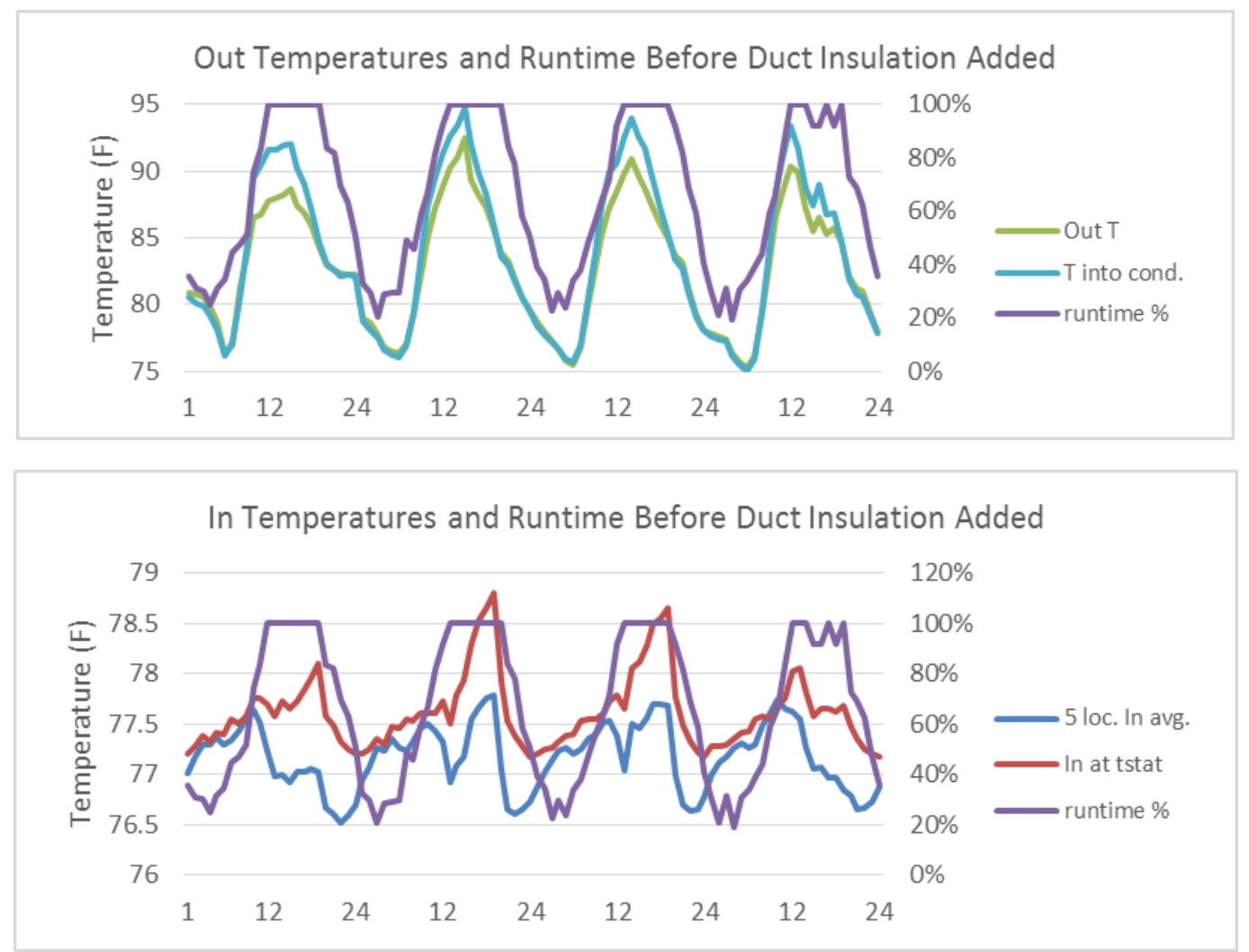

Figure 21. Outdoor and indoor temperatures with 2-ton SEER 13 system run time shown at hourly intervals before duct insulation wrap was added

While the post repair period also shows some hourly periods of $100 \%$ run time, there was no significant rise in interior temperature, particularly during those periods. Figure 22 shows the same information as Figure 21, except it is during the post-repair period. The third day of the post-repair period shown in Figure 22 has a very hot period of inlet condenser temperatures at about $95^{\circ} \mathrm{F}, 100 \%$ hourly run time, and yet the interior temperatures indicate the load is being met. 

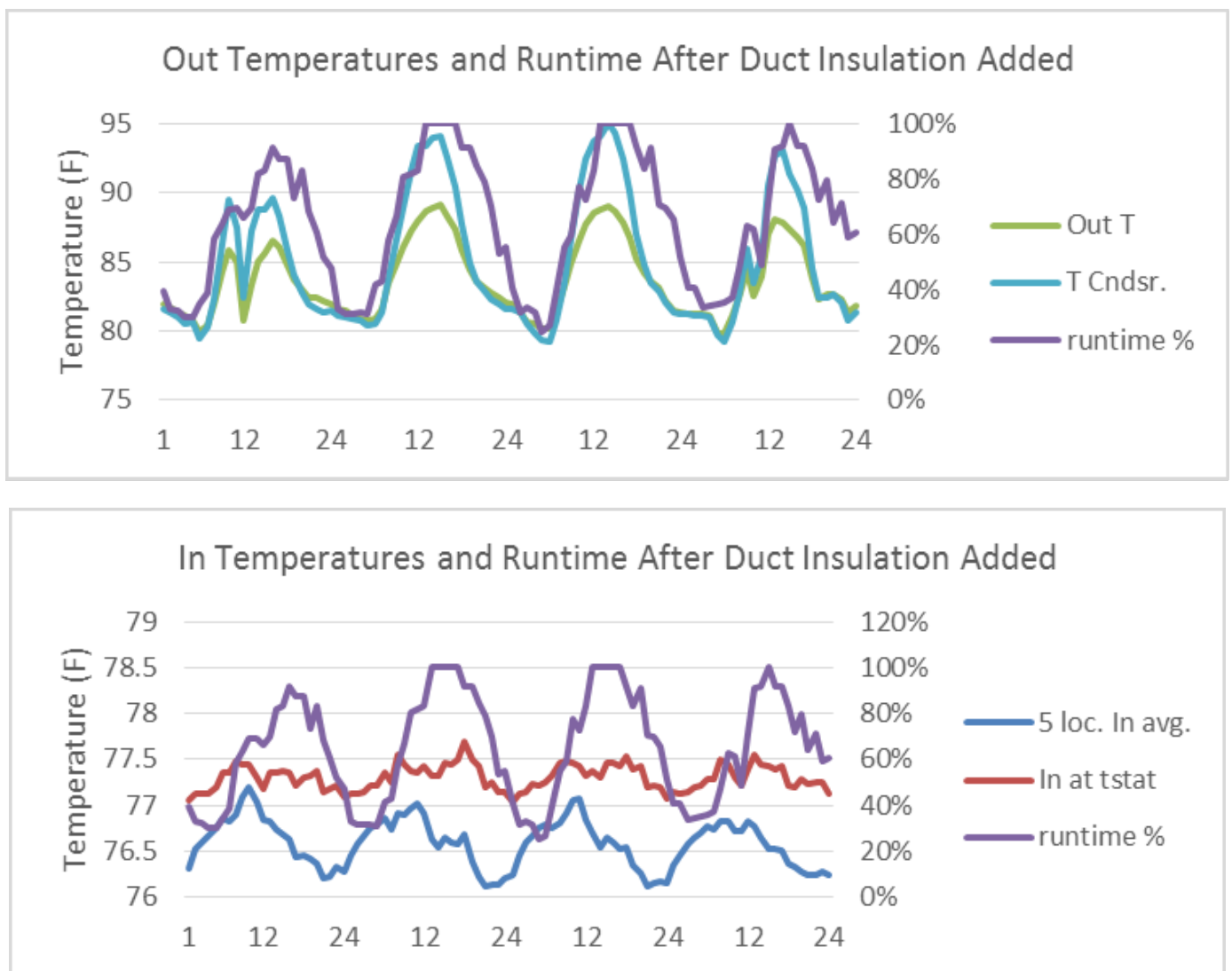

Figure 22. Outdoor and indoor temperatures with 2-ton SEER 13 system run time shown at hourly intervals after duct insulation wrap was added 


\section{Heating Season Energy}

Performance problems occurred for the variable-capacity SEER 22 heat pump during the postretrofit heating season (December 24, 2013-March 31, 2014). This followed a failure of the 2ton SEER 22 system in 2012, when it had repeated service problems and was eventually replaced in November 2012, about 12 months prior to this most recent equipment malfunction. Because of the equipment performance problems during the post-retrofit heating period, a large portion of the heating analysis that was planned for this project could not be performed. Details of the postretrofit system performance problems are presented in Section 6.1.

For the heating season experiments, the heat pump thermostats were set to $75^{\circ} \mathrm{F}$, as was done in previous experimental phases. This set point is higher than a typical winter heating set point for Floridians $\left(72^{\circ} \mathrm{F}\right.$ is believed to be more representative of a typical Florida heating set point). This elevated set-point temperature of $75^{\circ} \mathrm{F}$ was chosen to increase space heating loads and to produce longer heat pump run times, where heating degree days are limited to about 600 in an average winter (ASHRAE 2009). While the thermostat was set to $75^{\circ} \mathrm{F}$, actual indoor temperature averaged about $76.5^{\circ} \mathrm{F}$ on days when some heating was required (there are many days during the winter when cooling is needed or when neither heating nor cooling is required). The sensible internal load was also reduced during the heating experiments, from $27.7 \mathrm{kWh}$ /day to 21.1 $\mathrm{kWh}$ /day (as was done in all earlier phases), again to increase the net heating load and heat pump operation. It is important to note that the electric strip heating elements in the heat pumps were disabled so that electric resistance heating would not occur during these experiments, either as supplemental heat (in case the heat pumps had insufficient capacity) or during defrost cycles. Therefore, all of the heat produced by the heat pump system occurred as a result of compressor operation.

As before, regression analysis was used to characterize daily heating energy use as a function of daily average outdoor-minus-indoor temperature (Figure 23). As shown, heating energy for the SEER 22 system was considerably higher after the duct insulation retrofit, which of course is contrary to the expectation of heating energy use reduction after the retrofit. At a delta-T of $22^{\circ} \mathrm{F}\left(50^{\circ} \mathrm{F}\right.$ outdoors and $72^{\circ} \mathrm{F}$ indoors, a typical cold central Florida winter day), the calculated heating energy use was $12.42 \mathrm{kWh}$ /day pre-retrofit and $15.71 \mathrm{kWh}$ /day post-retrofit (based on the regression best-fit equations), indicating that the retrofit caused an $26.4 \%$ increase in heating energy use on a typical cold, Florida heating day. Clearly, there is a problem with this outcome. Either the sensor readings were in error (AHU cfm, $T_{\text {return, }}, T_{\text {supply }}$ at $A H U$ discharge, or power meter) or heat pump performance declined sharply. Environmental conditions such as attic temperatures do not provide an account for the discrepancy. The pre attic average temperature was $64.4^{\circ} \mathrm{F}$ and Post attic average temperature was $63.4^{\circ} \mathrm{F}$. A one degree difference is not adequate to account for a drop in heating performance that is discussed in Section 6.1 and illustrated in Figure 24. 


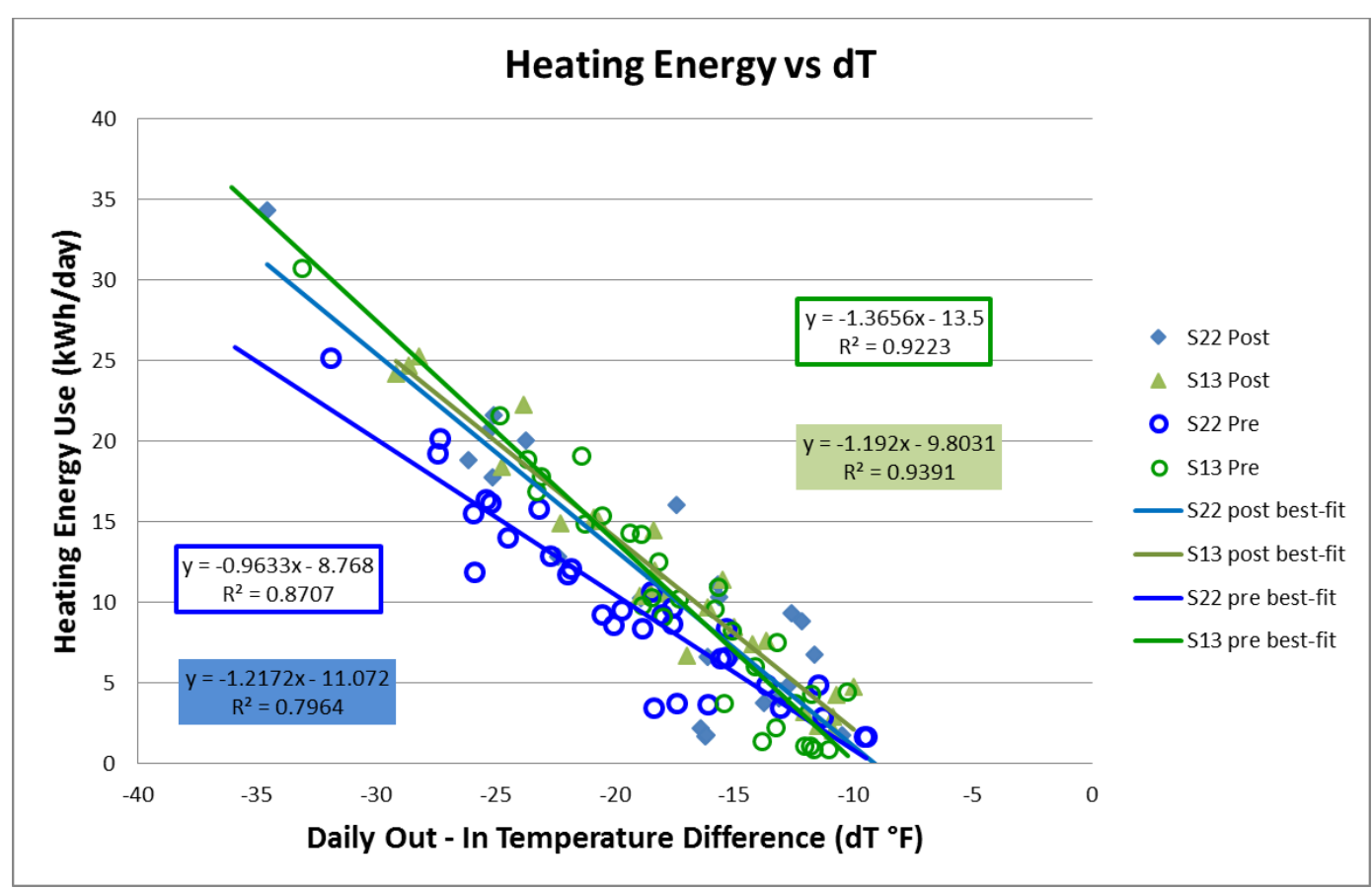

Figure 23. Daily heating energy use as a function of delta-T for the SEER 13 and SEER 22 heat pumps

\subsection{Discussion of Heating System Performance/Data Problems}

Steps were taken to check that the monitoring system (sensors and data loggers) was not the cause of the data problems. Data collected during earlier calibration checks was reviewed, and additional checks of temperatures, air flows, and power meter readings were taken. These checks revealed that sensor readings had remained stable and accurate over the approximately 15 -month monitoring period. Additionally, the SEER 22 heat pump was subsequently tested at three fixed heating capacity points (minimum, intermediate, and maximum) on April 9, 2014 (at $60^{\circ} \mathrm{F}$ ambient conditions). The test results found that the system was underperforming its ratings in terms of output by $38 \%$ and COP by $30 \%$ based on comparison to manufacturer performance tables. In the absence of any problems with the sensors and meters and with the system tests showing performance shortfall, the authors conclude that the heat pump performance declined prior to the post-retrofit heating period. (Note that there is no indication that cooling performance of the SEER 22 system was impacted.)

An alternative analysis was also used to assess the heating performance shortfall. The energy efficiency of the SEER 22 heat pump was examined for 15-minute time periods. Figure 24 presents heating EER (Btu heating output per Wh of electrical input) as a function of $\mathrm{T}_{\text {ambient. }}$. At an outdoor temperature of $50^{\circ} \mathrm{F}$, heating EER is $29.4 \%$ higher during the pre-retrofit period compared to the post-retrofit period, based on the regression best-fit equations. It can also be stated that the heating EER was $22.7 \%$ lower during the post-retrofit period. Note that the plotted EER values do not include any effect from duct system efficiency, since measured heating output (that forms the basis for the EER calculation) is based on temperature rise from entry to discharge of the AHU. Because the AHU is located in the conditioned space, losses from the AHU alone would be minimal. 


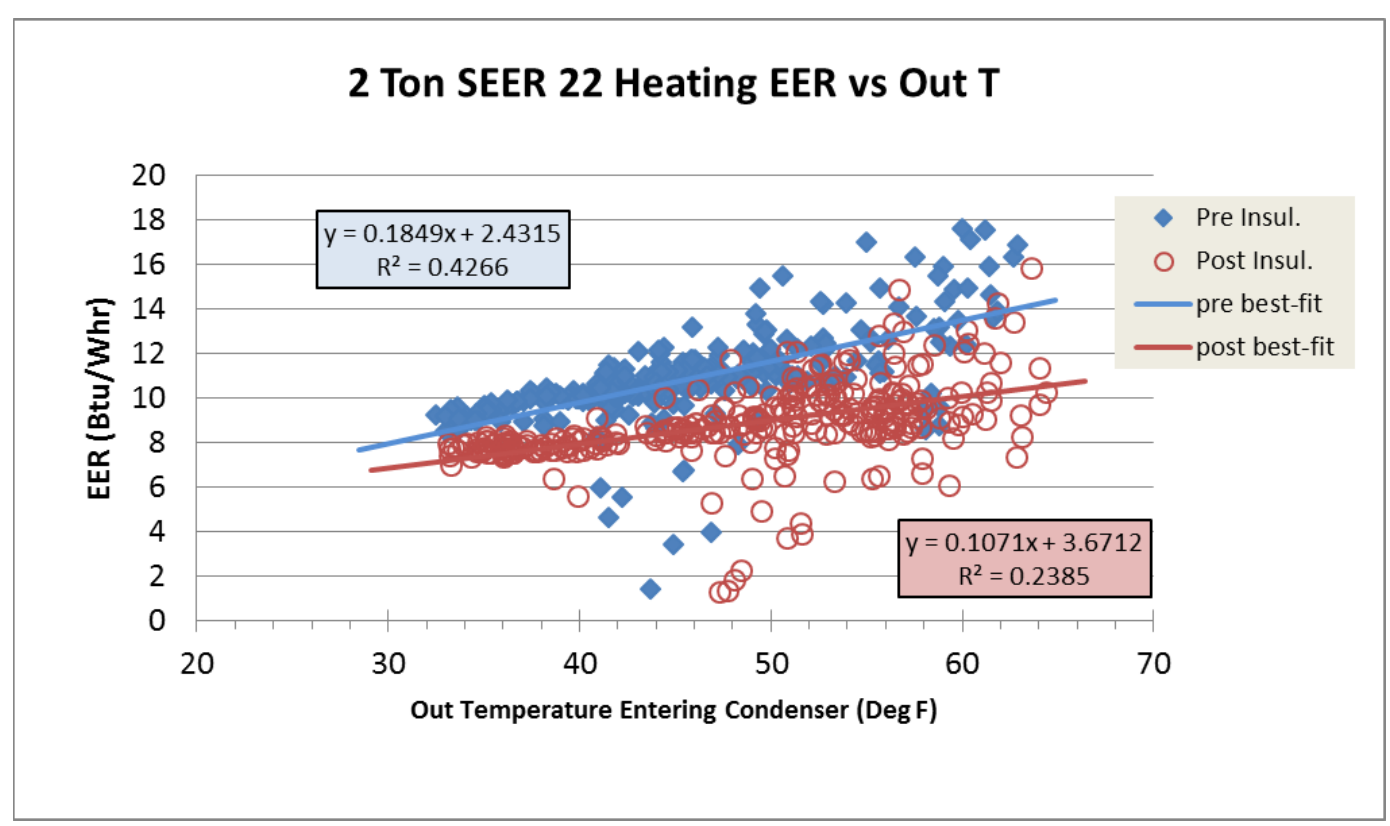

Figure 24. Heating EER for the SEER 22 two-ton heat pump for the pre- and post-retrofit periods. Data points represent 15 -minute periods with $100 \%$ AHU run time. Points falling far above the best-fit lines represent periods when system capacity was ramping down while points falling far below the best-fit lines represented either periods when system capacity was ramping up or when a defrost cycle was occurring.

If the heat pump had had the same heating EER during both the pre- and post-retrofit periods, then the post-retrofit energy use of $15.71 \mathrm{kWh} /$ day (at $-22^{\circ} \mathrm{F}$ delta-T) would have declined to $12.14 \mathrm{kWh} /$ day (calculation: $15.71 / 1.294=12.14$ ), indicating that the duct insulation retrofit caused a $2.3 \%$ reduction in heating energy use versus the pre-retrofit $12.42 \mathrm{kWh} /$ day, each at $22^{\circ} \mathrm{F}$ delta-T (calculation: $\left.(12.42-12.14) / 12.42=0.9975\right)$. This indicates that heating energy savings from the duct insulation upgrade might be about $2.3 \%$ as a result of increasing duct insulation from R-6.1 to R-11.6. There is uncertainty in this result, however, at least in part because the temperature of the supply air was about $3^{\circ} \mathrm{F}$ lower during the post-retrofit period compared to the pre-retrofit period. If the average run time-weighted temperature differential between inside the attic and inside the ductwork was $35^{\circ} \mathrm{F}$ for the pre-period and $32^{\circ} \mathrm{F}$ for the post-period, then the approximately $2.3 \%$ heating energy savings would have declined to about $2.1 \%$ savings when accounting for the smaller delta-T across the duct insulation.

While there were problems with the SEER 22 system during the heating season, there were no SEER 13 system performance problems. Therefore, heating energy savings can be calculated for the SEER 13 system. At $-22^{\circ} \mathrm{F}$ delta-T, pre-retrofit energy use was $16.543 \mathrm{kWh} /$ day while postretrofit energy use was $16.421 \mathrm{kWh} /$ day, indicating savings of $122 \mathrm{~W}(0.7 \%)$. It should be noted that at delta-T of $-32^{\circ} \mathrm{F}\left(10^{\circ} \mathrm{F}\right.$ colder than the typical cold Florida winter day), daily heating energy was indicated to be $6.2 \%$ lower as a result of the duct insulation retrofit. While savings are predicted, they are very low compared to the standard error of prediction which is about $1900 \mathrm{~W}$, and is nearly 15 times the indicated savings of $122 \mathrm{~W}$. 
In conclusion, because of the high uncertainty in predicted fixed-capacity (SEER13) heating savings and the performance failure of the variable-capacity (SEER 22) heat pump during the post-retrofit heating season, seasonal heating energy savings cannot be meaningfully obtained for the duct insulation retrofit. For the same reason, no heating peak demand savings analysis is presented either. 


\section{Summary and Conclusions}

Two primary research questions addressed by this research are (1) "How much improvement is there in system seasonal energy-efficiency results when duct insulation R-value is increased (from 6.1 to 11.6) for the fixed-capacity and variable-capacity 2-ton systems?" and (2) "How much reduction in peak demand occurs as a result of duct insulation retrofit for the fixedcapacity and variable-capacity systems?"

Note that the data obtained from this research was from weather that was typically hot and humid during cooling weather and only moderately cold during heating weather, so there will be only limited applicability to climate zones that are hot and dry or substantially cold (U.S. Department of Energy climate zones 5 and higher).

\subsection{Seasonal Cooling Energy Savings}

Because variable-capacity systems deliver cold air into the attic ducts about $55 \%-60 \%$ more hours per day than the fixed-capacity systems, and therefore experience greater duct conductive losses, it was expected that cooling energy savings from upgrading duct insulation would be greater for the variable-capacity systems. This expectation was met on a relative percentage basis, but it turned out to be a secondary effect on an absolute energy basis. Based on regression analysis of monitored data, increasing the effective duct system R-value from 6.1 to 11.6 produced greater cooling energy savings for the variable-capacity system compared to the fixedcapacity system. Savings of $6.4 \%, 6.9 \%$, and $8.2 \%$ were found (on a typical summer day with temperatures of $82^{\circ} \mathrm{F}$ outdoors and $77^{\circ} \mathrm{F}$ indoors) for the SEER 13 fixed-capacity system, the SEER 22 variable-capacity system (in standard control mode), and the SEER 22 variablecapacity system (in RH control mode with $45 \%$ set point), respectively. These percentages are relative to the higher and lower energy use of the fixed and variable-capacity systems respectively. This is a way of isolating the dwell air effect, but it does not give a sense of the absolute magnitude and importance of the effect. Observing the actual energy values (see Table 6) and normalizing the percentage calculations to the cooling energy used by the SEER 13 fixedcapacity unit with R6 ducts in the attic (the base case), the absolute effect of dwell air for fixedversus variable-capacity equipment ranged from about $2.4 \%$ to $-1.6 \%$ (0.57 to $-0.39 \mathrm{kwh} / \mathrm{day})$. In one case the effect is reversed, and adding insulation to the SEER 13 system actually saved more energy than adding insulation to the SEER 22 system. For the case that showed the maximum dwell air effect $(0.57 \mathrm{kwh} /$ day), the difference in "dwell air" effect between the variable- and fixed-capacity systems amounted to a maximum of about $\$ 20 /$ year. The savings going from a SEER 13 to a SEER 22 apparatus was much greater (4.9 to $7.3 \mathrm{kwh} /$ day) $(20 \%$ to $30 \%)$, depending on duct placement and insulation level. The next greatest effect was going from an R6 duct in the attic to an R6 duct within the conditioned space $(2.94$ to $3.51 \mathrm{kwh} /$ day) (12\% to $15 \%)$.

\subsection{Cooling Peak Demand Savings}

Because both the fixed-capacity and the variable-capacity 2 -ton systems were operating $100 \%$ of the time during peak hours (about $92^{\circ} \mathrm{F}$ outdoors), conductive losses through the duct insulation jacket would be expected to be very nearly the same for both systems. Nevertheless, regression analysis found greater peak demand reduction for the variable-capacity system: $2.9 \%, 15.3 \%$, and $11.7 \%$ demand reduction for the SEER 13, SEER 22, and SEER 22 (45\%) system configurations, respectively, at 15 degrees delta- $\mathrm{T}\left(92^{\circ} \mathrm{F}\right.$ outdoors and $77^{\circ} \mathrm{F}$ indoors $)$. 
However, peak demand savings for the SEER 13 system was depressed because the unit had insufficient capacity to meet the cooling load during the hottest hours (see discussion in Section 5.1). This would tend to increase the apparent relative importance of the dwell air effect for the variable-capacity systems. This was especially true for the pre-retrofit period.

On the other hand, if the systems had been oversized (such as the 3-ton systems in Phase 1 and Phase 2), it is expected that the benefit of upgraded duct insulation would have been greater for the variable-capacity system. In Phase 1 when 3-ton systems were in use, the variable-capacity system operated $100 \%$ of the time during peak hours, whereas the fixed-capacity system was typically only at $65 \%-70 \%$ run time. Therefore, because the fixed-capacity system was delivering cold air into the ducts for only $65 \%-70 \%$ of the time, during peak coolin, it would experience reduced conductive heat gains compared to the variable-capacity system.

\subsection{Heating Season Savings}

An unrecognized heating performance problem occurred with the SEER 22 variable-capacity heat pump during the post-retrofit winter period. (All indications are that the system was fine during the pre-retrofit heating period and during both the pre- and post-retrofit cooling periods.) During the post-retrofit heating period, it operated at 22.7\% lower efficiency compared to the pre-retrofit period (Figure 24). As a result, both seasonal and peak demand heating analysis was unavailable for the SEER 22 system.

Regression analysis for the fixed-capacity SEER 13 system found $0.7 \%$ seasonal heating savings as a result of the duct insulation retrofit. This is too small to be considered significant given the high uncertainty of prediction due to limited heating data, much of which was during mild conditions. 


\section{References}

Andrews, J. W. (2002). Duct Retrofit Strategy To Complement A Modulating Furnace. Upton, NY: Brookhaven National Laboratory. Accessed April 2014:

http:/www.bnl.gov/isd/documents/24650.pdf

ASHRAE. (2009). “Appendix: Design Conditions for Selected Locations," Chapter 14. ASHRAE Handbook - Fundamentals 2009.

ASTM C-1340. (2010). Standard Practice for Estimation of Heat Gain or Loss Through Ceilings Under Attics Containing Radiant Barriers by Use of a Computer Program. West Conshohocken, PA: ASTM International.

Cengel, Y. A. (1998). Heat Transfer: A Practical Approach. McGraw-Hill Companies, Inc.

Chasar, D.; Withers, C. (2013). Measured Cooling Performance and Potential for Buried Duct Condensation in a 1991 Central Florida Retrofit Home. NREL/KNDJ-0-40339-00. Cocoa, FL: FSEC. Accessed April 2014: http://www.fsec.ucf.edu/en/publications/pdf/FSEC-CR-194613.pdf

Cummings, J.; Withers, C. (2011). Energy Savings and Peak Demand Reduction of a SEER 21 Heat Pump vs. a SEER 13 Heat Pump with Attic and Indoor Duct Systems. NREL/KNDJ-040339-02. Cocoa, FL: FSEC. Accessed April 2014: http://www.fsec.ucf.edu/en/publications/pdf/FSEC-CR-1927-11.pdf

Cummings, J.; Withers, C. (2013). Energy Savings and Peak Demand Reduction of a SEER 21 Heat Pump vs. a SEER 13 Heat Pump when Duct Leaks are Added to Attic Ductwork. NREL/KNDJ-0-40339-02. Cocoa, FL: FSEC.

Cummings, J.; Withers, C., and Kono, J. (2014). Draft Final Report: Cooling and Heating Season Impacts of "Right Sizing" of Fixed Capacity (SEER 13) and Variable Capacity (SEER 22 and 21) Heat Pumps with Attic and Indoor Ductwork. NREL/ KNDJ-0-40339-02. Cocoa, FL: FSEC.

Hendron, R. (2008). Building America Research Benchmark Definition (BARBD). NREL/TP550-44816. Golden, CO: National Renewable Energy Laboratory. Accessed April 2014: http://apps1.eere.energy.gov/buildings/publications/pdfs/building_america/44816.pdf

James, W. L. (1988). Electric Moisture Meters for Wood. United States Department of Agriculture Forest Service General Technical Report. FPL-GTR-6.Washington, DC: Forest Products Laboratory. Accessed April 2014: http:/www.fpl.fs.fed.us/documnts/fplgtr/fplgtr06.pdf

Kays, W. M.; Crawford, M. E. (1993). Convective Heat and Mass Transfer. 3rd edition. McGraw Hill.

Nordyne Elite Training. (2009). IQ Drive Heat Pump Training Manual. Document \#303D-0409, Technical Training Division. 
Palmiter, L.; Kruse, E. (2006). "True R-Values of Round Residential Ductwork.” ACEEE Summer Study on Energy Efficiency in Buildings Proceedings. Accessed April 2014:

http://aceee.org/files/proceedings/2006/data/papers/SS06_Panel1_Paper18.pdf

Shapiro, C.; Magee, A; Zoeller, W. (2013). Reducing Thermal Losses and Gains With Buried and Encapsulated Ducts in Hot-Humid Climates. NREL/KNDJ-0-40342-00. Norwalk, CT: Consortium for Advanced Residential Buildings (CARB). Accessed April 2014:

http://apps1.eere.energy.gov/buildings/publications/pdfs/building_america/encaps ducts hothum id.pdf 


\section{Appendix A}

Performance specifications for the Nordyne iQ Drive heat pumps.

SYSTEM COOLING CAPACITIES

22 SEER - Ultra High Efficiency - Single Phase

\begin{tabular}{|l|l|l|l|l|l|l|}
\hline Outdoor Unit & Indoor Unit & $\begin{array}{l}\text { Range } \\
\text { Cooling } \\
\text { Capacity } \\
\text { FT4BI- } \\
\text { @ } \begin{array}{l}95^{\circ} \text { OD } \\
\text { BTUH }\end{array}\end{array}$ & $\begin{array}{l}\text { EER @ } \\
\text { Nominal } \\
\text { Capacity }\end{array}$ \\
& SEER & $\begin{array}{l}\text { Nominal } \\
\text { Capacity }\end{array}$ & $\begin{array}{l}\text { Range } \\
\text { SCFM }\end{array}$ \\
\hline $024 \mathrm{~K}$ & $\begin{array}{l}\text { B4VM-E24K- } \\
\text { B }\end{array}$ & $\begin{array}{l}11,300-26,900 \\
\text { B4VM-E36K- }\end{array}$ & 14.6 & 22 & 23,000 & $500-950$ \\
\hline $048 \mathrm{~K}$ & $\begin{array}{l}\text { B4VM-E48K- } \\
\text { C }\end{array}$ & $14,300-48,000$ & 12.5 & 21 & 44,500 & $\begin{array}{l}725- \\
1800\end{array}$ \\
\hline
\end{tabular}

NOTE: Each system was operated at its nominal capacity.

Indoor conditions were $80^{\circ} \mathrm{F}$ dry-bulb temperature and $67^{\circ} \mathrm{F}$ wet-bulb temperature (approx. $51 \%$ relative humidity, $95^{\circ} \mathrm{F}$ outdoor temperature

SYSTEM HEATING CAPACITIES

22 SEER - Ultra High Efficiency - Single Phase

\begin{tabular}{|c|c|c|c|c|c|c|}
\hline $\begin{array}{l}\text { Outdoor Unit } \\
\text { Model Number } \\
\text { FT4BI- }\end{array}$ & Indoor Unit & $\begin{array}{l}\text { Range } \\
\text { Heating Capacity } \\
\text { @ } 47^{\circ} \text { OD } \\
\text { BTUH }\end{array}$ & $\begin{array}{l}\text { Nominal } \\
\text { Capacity }\end{array}$ & HSPF & $\begin{array}{l}\text { COP } \\
\text { @ Nomina } \\
\text { 1 Capacity }\end{array}$ & CFM \\
\hline $024 \mathrm{~K}$ & $\begin{array}{l}\text { B4VM-E24K- } \\
\text { B }\end{array}$ & $6,500-24,100$ & 22,600 & 10 & 3.9 & $500-950$ \\
\hline $036 \mathrm{~K}$ & $\begin{array}{l}\text { B4VM-E36K- } \\
\text { B }\end{array}$ & $11,300-39,800$ & 34,000 & 9.6 & 3.4 & $\begin{array}{l}680- \\
1110\end{array}$ \\
\hline $048 \mathrm{~K}$ & $\begin{array}{l}\text { B4VM-E48K- } \\
\text { C }\end{array}$ & $11,400-47,800$ & 46,000 & 10 & 3.6 & $\begin{array}{l}725- \\
1800\end{array}$ \\
\hline
\end{tabular}


Minimum operating ambient temperature is $12^{\circ} \mathrm{F}$

NOTE: Heating seasonal performance factor, HSPF

Each system was operated at its nominal capacity.

Indoor conditions $=70^{\circ} \mathrm{F}$ dry-bulb temperature. Outdoor conditions $=47^{\circ} \mathrm{F}$ dry-bulb and $43^{\circ} \mathrm{F}$ wet-bulb temperature.

Source: Frigidaire FT4BI Series Technical Specifications.

http://www.nordyne.com/Literature/931D.pdf 


\section{Appendix B}

Procedure for Estimating "Effective" R-Value of Supply Ducts Installed in Attics from Measured Data

\section{Introduction}

The approach used to estimate the effective R-value of supply duct works from measured parameters is described. Measured parameters include: supply air flow rates, supply air temperatures, attic air and attic surface temperatures, conditioned space temperatures, and duct geometry. This method is used to predict two effective R-values; air-to-air and surface-tosurface. The former includes the inside and outside film resistances and the latter does not. The air-to-air effective R-value of a supply ductwork system is determined from total duct heat transfer rate and area weighted log mean temperature difference (LMTD) between the supply air stream and the environment. The total heat transfer rate is calculated from the measured air flow rates and supply air temperatures rise from AHU discharge to supply registers. The surface-tosurface duct R-value is backed out from the air-to-air R-value using duct inside and outside average resistances. The duct inside film thermal resistance is estimated from forced flow convective heat transfer coefficient, and the outside thermal resistance is a combined resistance of free convection and radiation heat transfer coefficients from the duct outside surface to the environment. This procedure requires that the various temperatures and flow rates are measured at a steady state condition. The following measured data are required as an input to the model:

- Supply air volume flow rate at the exit of each diffuser

- Supply air temperature at the entrance to the attic supply duct system

- Supply air temperature at the exit of each supply air diffuser

- Attic air temperature and attic surface temperatures

- Ducts system surface area and inside and outside diameters.

\section{Mathematical Model and Assumptions}

The following assumptions were made in the formulation of the procedure for effective R-value calculation:

- Steady state duct heat transfer model

- No supply duct air leakage

- Ignores thermal mass of the ductwork

- Attic space average inside surfaces temperature

- Duct buried section is coupled to the conditioned space only and is treated by specifying buried fraction.

The effective R-value is determined from area weighted log-mean temperature difference as the driving force, the duct heat transfer rate, and the entire duct outside surface area. The effective air-to-air R-Value is given by Eq. 1: 


$$
\text { RValue }_{\text {AToA }}=\frac{\text { AreaLMTD }_{\text {Tot }}}{\dot{Q}_{\text {Tot }}}
$$

where,

- $\quad$ AreaLMTD $D_{\text {Tot }}=$ Area weighted log-mean temperature difference of the ductwork, $\mathrm{m}^{2}-{ }^{\circ} \mathrm{C}\left(\mathrm{ft}^{2}-{ }^{\circ} \mathrm{F}\right)$

- $\dot{Q}_{T o t}=$ Supply air ductwork total heat transfer rate, $\mathrm{W}(\mathrm{Btu} / \mathrm{hr})$

The total duct heat transfer rate is calculated from supply air flow rates and temperature difference between air leaving the air handling unit or air entering the supply duct main trunk and supply diffuser outlets measured at a steady state condition. Schematic illustration of the ductwork layout and duct run paths are shown in Figure B-1 and Figure B-2, respectively. Five duct run paths for the supply ductwork system are shown in Figure B-1.

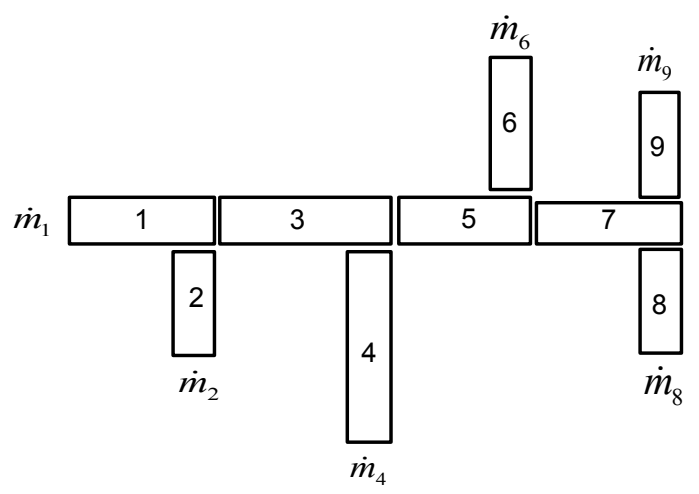

Figure B-1. Schematic of supply duct layout

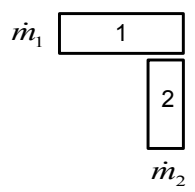

Duct Run Path-1

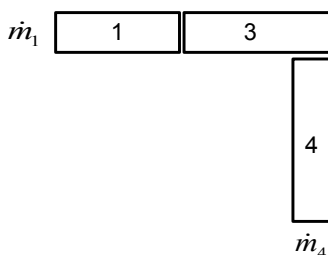

Duct Run Path-2

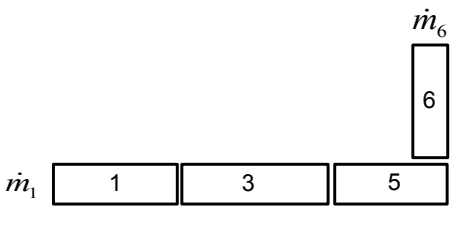

Duct Run Path-3

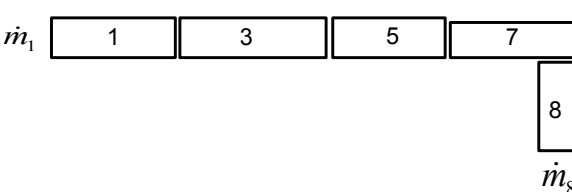

Duct Run Path-4

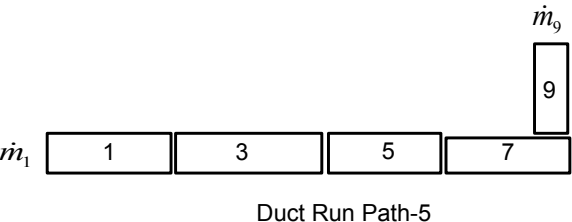

Figure B-2. Supply duct run paths

The supply duct total heat transfer rate is determined by summing the heat transfer rate along the duct run paths and is given by Eq. 2 and Eq. 3 . 


$$
\dot{Q}_{T o t}=\sum_{j=1}^{N} \dot{m}_{j} \cdot c_{p} \cdot\left(T_{\text {In }}-T_{\text {Out }, j}\right)
$$

or

$$
\dot{Q}_{\text {Tot }}=\sum_{j=1}^{N} \dot{m}_{j} \cdot\left(H_{\text {In }}-H_{O u t, j}\right)
$$

where,

- $\dot{m}_{j}=$ supply mass flow rate of the jth duct run path, $\mathrm{kg} / \mathrm{s}(\mathrm{lb} / \mathrm{hr})$

- $c_{p}=\quad$ specific heat of supply air at duct entrance, $\mathrm{J} / \mathrm{kg}-{ }^{\circ} \mathrm{C}\left(\mathrm{Btu} / \mathrm{lb}{ }_{\mathrm{m}} \cdot{ }^{\circ} \mathrm{F}\right)$

- $T_{I n}=$ air handling unit leaving or supply duct entering air temperature, ${ }^{\circ} \mathrm{C}\left({ }^{\circ} \mathrm{F}\right)$

- $T_{\text {Out }, j}=\quad$ supply air temperature at the $\mathrm{j}^{\text {th }} \operatorname{diffuser}$ outlet, ${ }^{\circ} \mathrm{C}\left({ }^{\circ} \mathrm{F}\right)$

- $\mathrm{N}=$ number of duct run paths, (-)

- $H_{I n}=$ air handling unit leaving or supply duct entering air enthalpy, $\mathrm{J} / \mathrm{kg}(\mathrm{Btu} / \mathrm{lb})$

- $H_{O u t, j}=$ supply air enthalpy at the jth diffuser outlet, $\mathrm{J} / \mathrm{kg}(\mathrm{Btu} / \mathrm{lb})$

The average log-mean temperature difference for the entire duct work is determined by summing the area-weighted LMTD of the individual duct run paths and is given by Eq. 4.

$$
\text { AreaLMTD }_{\text {Tot }}=\sum_{j=1}^{N} \text { AreaLMTD }_{j}
$$

where,

- $\quad$ AreaLMTD $D_{j}=\quad$ area times log-mean temperature difference of the $\mathrm{j}^{\text {th }}$ duct run path, $\mathrm{m}^{2}-{ }^{\circ} \mathrm{C}\left(\mathrm{ft}^{2}-{ }^{\circ} \mathrm{F}\right)$

The area weighted LMTD for each duct run path is given by Eq. 5. This equation accounts for the buried and unburied fractions of a duct section in a duct run path. The heat transfer area of main duct sections is apportioned for each duct run path according to the flow fraction. The flow fraction represents the area fraction of a duct section available for a given duct run path.

$$
\operatorname{AreaLMTD}_{j}=\operatorname{LMTD}_{j} \sum_{i=1}^{M}\left(A_{i} \cdot \frac{\dot{V}_{j}}{\dot{V}_{i}} \cdot\left(1-F_{i, b}\right)\right)+\operatorname{LMTD}_{j, b} \sum_{i=1}^{M}\left(A_{i} \cdot \frac{\dot{V}_{j}}{\dot{V}_{i}} \cdot F_{i, b}\right)
$$

where, 
- $\mathrm{M}=$ number of duct sections in a single duct run path, (-)

- $\operatorname{LMTD}_{j}=$ log-mean temperature difference of the $\mathrm{j}^{\text {th }}$ duct run path, $\mathrm{m}^{2}-{ }^{\circ} \mathrm{C}$ $\left(\mathrm{ft}^{2}-{ }^{\circ} \mathrm{F}\right)$

- $\operatorname{LMTD}_{j, b}=$ buried duct log-mean temperature difference of the $\mathrm{j}^{\text {th }}$ duct run path, $\mathrm{m}^{2}{ }^{\circ} \mathrm{C}\left(\mathrm{ft}^{2}-{ }^{\circ} \mathrm{F}\right)$

- $A_{i}=$ duct surface area of the $\mathrm{i}^{\text {th }}$ duct section, $\mathrm{m}^{2}\left(\mathrm{ft}^{2}\right)$

- $F_{i, b}=$ buried area fraction of the $\mathrm{i}^{\text {th }}$ duct section, (-)

- $\dot{V}_{j}=$ volume flow rate of supply air along the $\mathrm{j}^{\text {th }}$ duct run path, $\mathrm{m}^{3} / \mathrm{s}\left(\mathrm{ft}^{3} / \mathrm{s}\right)$

- $\dot{V}_{i}=$ volume flow rate of supply air in the $\mathrm{i}^{\text {th }}$ duct section, $\mathrm{m}^{3} / \mathrm{s}\left(\mathrm{ft}^{3} / \mathrm{s}\right)$

The log-mean temperature difference is calculated assuming a constant environment temperature as a boundary condition. Figure B-3 illustrates the thermal network representation of buried and unburied duct sections. The unburied duct surface exchanges heat with the attic air and the attic surfaces. The buried fraction of a duct is assumed to be coupled to a conditioned space air temperature below through the attic floor. A one-dimensional heat transfer representation of a buried duct is a simplification; otherwise, buried part of a duct may experience multidimensional duct conduction heat transfer. A partially buried duct is in part coupled to the attic space and in part to the conditioned space below.

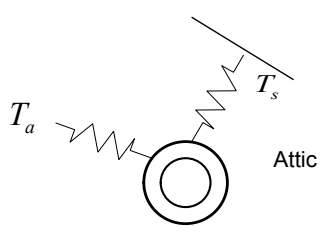

Unburied duct section

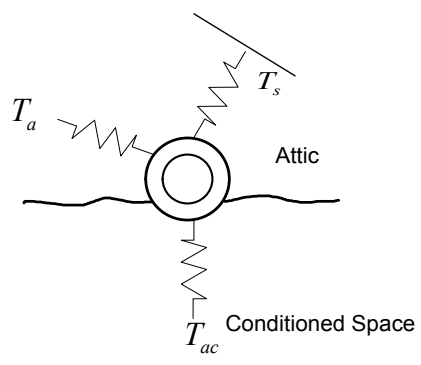

Partially buried duct section

Figure B-3. Buried and unburied ducts thermal network representation

For unburied and buried duct sections along the $\mathrm{j}^{\text {th }}$ duct run path the LMTD are given by Eq. 6 and Eq. 7, respectively: 


$$
\begin{aligned}
\operatorname{LMTD}_{j}= & \frac{\left(T_{e, j}-T_{\text {In }}\right)-\left(T_{e, j}-T_{\text {Out }, j}\right)}{\ln \left[\frac{T_{e, j}-T_{\text {In }}}{T_{e, j}-T_{\text {Out }, j}}\right]} \\
\text { LMTD }_{j, b} & =\frac{\left(T_{a c}-T_{\text {In }}\right)-\left(T_{a c}-T_{\text {Out }, j}\right)}{\ln \left[\frac{T_{a c}-T_{I n}}{T_{a c}-T_{\text {Out }, j}}\right]}
\end{aligned}
$$

where,

- $T_{a}=$ attic space air temperature, ${ }^{\circ} \mathrm{C}\left({ }^{\circ} \mathrm{F}\right)$

- $T_{e, j}=$ attic space average environment temperature of the $\mathrm{j}^{\text {th }}$ duct run-path, ${ }^{\circ} \mathrm{C}$ $\left({ }^{\circ} \mathrm{F}\right)$

- $T_{I n}=$ supply air temperature entering a duct run path, ${ }^{\circ} \mathrm{C}\left({ }^{\circ} \mathrm{F}\right)$

- $T_{\text {Out }, j}=$ supply air temperature leaving the $\mathrm{j}^{\text {th }}$ duct run path, ${ }^{\circ} \mathrm{C}\left({ }^{\circ} \mathrm{F}\right)$

- $T_{a c}=$ conditioned space air temperature, ${ }^{\circ} \mathrm{C}\left({ }^{\circ} \mathrm{F}\right)$

For the unburied duct section the effective environment temperature is the weighted average of the attic air temperature and the average attic inside surfaces temperature. The average attic inside surfaces temperature is as the arithmetic mean of the inside temperature of the different surfaces in the attic. The effective environment temperature for each duct-run path is given by Eq. 8. This equation is a simplified version adopted from ASTM C-1340 (ASTM C-1340 2010).

$$
T_{e, j}=\frac{h_{c o, j} T_{a}+h_{r o, j} T_{s}}{\left(h_{c o, j}+h_{r o, j}\right)}
$$

where,

- $T_{s}=$ attic space mean inside surfaces temperature, ${ }^{\circ} \mathrm{C}\left({ }^{\circ} \mathrm{F}\right)$

- $h_{c o, j}=$ duct outside surface convection coefficient of the jth duct run path, W/m2-

${ }^{\circ} \mathrm{C}\left(\mathrm{Btu} / \mathrm{hr}-\mathrm{ft} 2-^{\circ} \mathrm{F}\right)$

- $h_{r o, j}=$ duct outside surface radiative coefficient of the jth duct run path, W/m2-

${ }^{\circ} \mathrm{C}\left(\mathrm{Btu} / \mathrm{hr}-\mathrm{ft} 2-^{\circ} \mathrm{F}\right)$

The duct outside convective heat transfer coefficient is calculated from empirical free convection heat transfer correlation (Kays and Crawford 1993). For laminar flow the Nusselt number is given by Eq. 9: 


$$
N u=\frac{0.518 R a^{1 / 4}}{\left[1+\left(\frac{0.599}{\operatorname{Pr}}\right)^{3 / 5}\right]^{5 / 12}}
$$

For turbulent flow the Nusselt number is given by Eq. 10:

$$
N u=0.1 R a^{1 / 3}
$$

The duct outside convection coefficient is determined using Eq. 11:

$$
h_{c o}=\frac{N u \cdot k_{a i r}}{D_{o}}
$$

where,

- $\mathrm{Nu}=$ Nusselt number, (-)

- $\operatorname{Re}=$ Reynolds number, (-)

- $\operatorname{Pr}=$ Prandtl number of air, (-)

- $k_{\text {air }}=$ Thermal conductivity of air, $\mathrm{W} / \mathrm{m}-{ }^{\circ} \mathrm{C}\left(\mathrm{Btu} / \mathrm{hr}-\mathrm{ft}-{ }^{\circ} \mathrm{F}\right)$

- $D_{0}=$ Duct outside diameter, $\mathrm{m}$ (in)

- $h_{c o}=$ Duct outside convection coefficient, $\mathrm{W} / \mathrm{m}^{2}-{ }^{\circ} \mathrm{C}\left(\mathrm{Btu} / \mathrm{hr}-\mathrm{ft}^{2}-{ }^{\circ} \mathrm{F}\right)$

The radiative heat transfer coefficient between the duct outside surface and the attic space at average surface temperature is estimated using Eq. 12:

$$
h_{r o, j}=\frac{\sigma\left[\left(T_{d s, j}+273.15\right)+\left(T_{s}+273.15\right)\right]\left[\left(T_{d s, j}+273.15\right)^{2}+\left(T_{s}+273.15\right)^{2}\right]}{\frac{1}{\varepsilon_{d s}}+\frac{1}{\varepsilon_{d s}}-1}
$$

where,

- $T_{d s, j}=$ the $\mathrm{j}^{\text {th }}$ duct run path exterior surface average temperature, ${ }^{\circ} \mathrm{C}\left({ }^{\circ} \mathrm{F}\right)$

- $\varepsilon_{d s} \quad=\quad$ duct outside surface average emissivity, (-)

- $\varepsilon_{s}=$ attic inside surfaces average emissivity, (-)

The outside convective and radiative heat transfer coefficients calculation require knowledge of the duct outside surface temperature. The $\mathrm{j}^{\text {th }}$ duct run path average surface temperature derived from the calculated energy balance is given by Eq. 13. The duct exterior surface temperature is determined iteratively. 


$$
T_{d s, j}=\frac{-\dot{Q}_{j}+T_{a} \sum_{i=1}^{M} A_{i} h_{c, i}+T_{s} \sum_{i=1}^{M} A_{i} h_{r, i}}{\left(\sum_{i=1}^{M} A_{i} h_{c, i}+\sum_{i=1}^{M} A_{i} h_{r, i}\right)}
$$

where,

- $\dot{Q}_{i}=$ heat transfer rate of the $\mathrm{j}^{\text {th }}$ duct run path, $\mathrm{W}(\mathrm{Btu} / \mathrm{hr})$

- $A_{i}=$ outside surface area of $\mathrm{i}^{\text {th }}$ duct section in the $\mathrm{j}^{\text {th }}$ duct run path, $\mathrm{m}^{2}\left(\mathrm{ft}^{2}\right)$

- $h_{c, i}=$ outside convection coefficient of $\mathrm{i}^{\text {th }}$ duct in the $\mathrm{j}^{\text {th }}$ duct run path, $\mathrm{W} / \mathrm{m}^{2}-{ }^{\circ} \mathrm{C}$ $\left(\mathrm{Btu} / \mathrm{hr}-\mathrm{ft}^{2}-{ }^{\circ} \mathrm{F}\right)$

- $h_{r, i}=$ duct outside radiation coefficient of $\mathrm{i}^{\text {th }}$ duct in the jth duct run path, $\mathrm{W} / \mathrm{m}^{2}$ ${ }^{\circ} \mathrm{C}\left(\mathrm{Btu} / \mathrm{hr}-\mathrm{ft}^{2}-{ }^{\circ} \mathrm{F}\right)$

The surface-to-surface effective R-value is calculated from the air-to-air effective R-value and the ductwork inside and outside average film thermal resistances using Eq. 14. This approach assumes uniform inside and outside film resistances over the entire ductwork and is based an overall heat transfer coefficient calculated procedure taken from Cengel (1998).

$$
\text { Rvalue }_{\text {SToS }}=\text { Rvalue }_{\text {AToA }}-R_{\text {Inside }}-R_{\text {Outside }}
$$

where,

- Rvalue $_{\text {AToA }}=$ average air-to-air R-value of the ductwork given by Eq. $1, \mathrm{~m}^{2}$ ${ }^{\circ} \mathrm{C} / \mathrm{W}\left(\mathrm{hr}-\mathrm{ft}^{2}-{ }^{\circ} \mathrm{F} / \mathrm{Btu}\right)$

- $R_{\text {Inside }}=$ average inside thermal resistance of the ductwork, $\mathrm{m}^{2}-{ }^{\circ} \mathrm{C} / \mathrm{W}\left(\mathrm{hr}-\mathrm{ft}^{2}-\right.$ $\left.{ }^{\circ} \mathrm{F} / \mathrm{Btu}\right)$

- $R_{\text {Outside }}=$ average outside thermal resistance of the ductwork, $\mathrm{m}^{2}-^{\circ} \mathrm{C} / \mathrm{W}$ (hr$\left.\mathrm{ft}^{2}-{ }^{\circ} \mathrm{F} / \mathrm{Btu}\right)$

The duct inside average resistance is area-weighted average inside convection coefficients for the entire duct works. The inside convection coefficient of a duct section is calculated from empirical correlation (Kays and Crawford 1993) given by Eq. 15:

$$
\begin{aligned}
& N u=0.022 \operatorname{Re}^{0.8} \operatorname{Pr}^{0.5} \\
& h_{i}=\frac{N u \cdot k_{\text {air }}}{D_{i}}
\end{aligned}
$$

where, 
- $N u=$ Nusselt number, (-)

- $\operatorname{Re} \quad=\quad$ Reynolds number, $(-)$

- $\operatorname{Pr} \quad=\quad$ Prandtl number of air, $(-)$

- $k_{\text {air }}=$ Thermal conductivity of air, $\mathrm{W} / \mathrm{m}-{ }^{\circ} \mathrm{C}\left(\mathrm{Btu} / \mathrm{hr}-\mathrm{ft}-{ }^{\circ} \mathrm{F}\right)$

- $D_{i}=$ Duct inside diameter, $\mathrm{m}$ (in)

- $h_{i}=$ Duct inside convection coefficient, $\mathrm{W} / \mathrm{m}^{2}-{ }^{\circ} \mathrm{C}\left(\mathrm{Btu} / \mathrm{hr}-\mathrm{ft}^{2}-{ }^{\circ} \mathrm{F}\right)$

The duct inside average thermal resistance is estimated from the inside convective heat transfer coefficient using Eq. 17.

$$
R_{\text {Inside }}=\frac{1}{\bar{h}_{i}}
$$

The area-weighted average inside convection coefficient is given by Eq. 18. The diameter ratio is introduced to account for the area difference between the duct inside and outside.

$$
\bar{h}_{i}=\frac{\sum_{k} h_{i, k} \cdot\left(\frac{D_{i}}{D_{o}}\right)_{k} \cdot A_{k}}{\sum_{k} A_{k}}
$$

The duct outside thermal resistance is calculated from the combined conductance of the convective and radiative components area-weighted over the entire ductwork and is given by Eq. 19 and Eq. 20.

$$
\begin{aligned}
& R_{\text {Ouside }}=\frac{1}{\bar{h}_{\text {combined }}} \\
& \bar{h}_{\text {combined }}=\frac{\sum_{k}\left(h_{c o}+h_{r o}\right)_{k} \cdot A_{k}}{\sum_{k} A_{k}}
\end{aligned}
$$

where,

- $D_{0}=$ duct outside diameter, $\mathrm{m}$ (in)

- $\bar{h}_{\text {combined }}=$ duct outside combined average conductance, $\mathrm{W} / \mathrm{m}^{2}-^{\circ} \mathrm{C}\left(\mathrm{Btu} / \mathrm{hr}-\mathrm{ft}^{2}\right.$ $\left.{ }^{\circ} \mathrm{F}\right)$

\section{Discussion}

The effective R-Value calculation procedure was implemented in MS EXCEL spreadsheet using VBA. Input parameters such as duct flow rates, surface area, duct diameter, buried fraction, and 
measured temperature data points are specified in the spreadsheet. The program reads in the data, processes the data, performs the "effective" R-Value calculation, and returns the R-Value corresponding to each data set. The effective R-value calculated from measured parameters is the weighted average for the entire duct system including the impact of different duct sizes. Figure B-4 presents attic duct system layout.

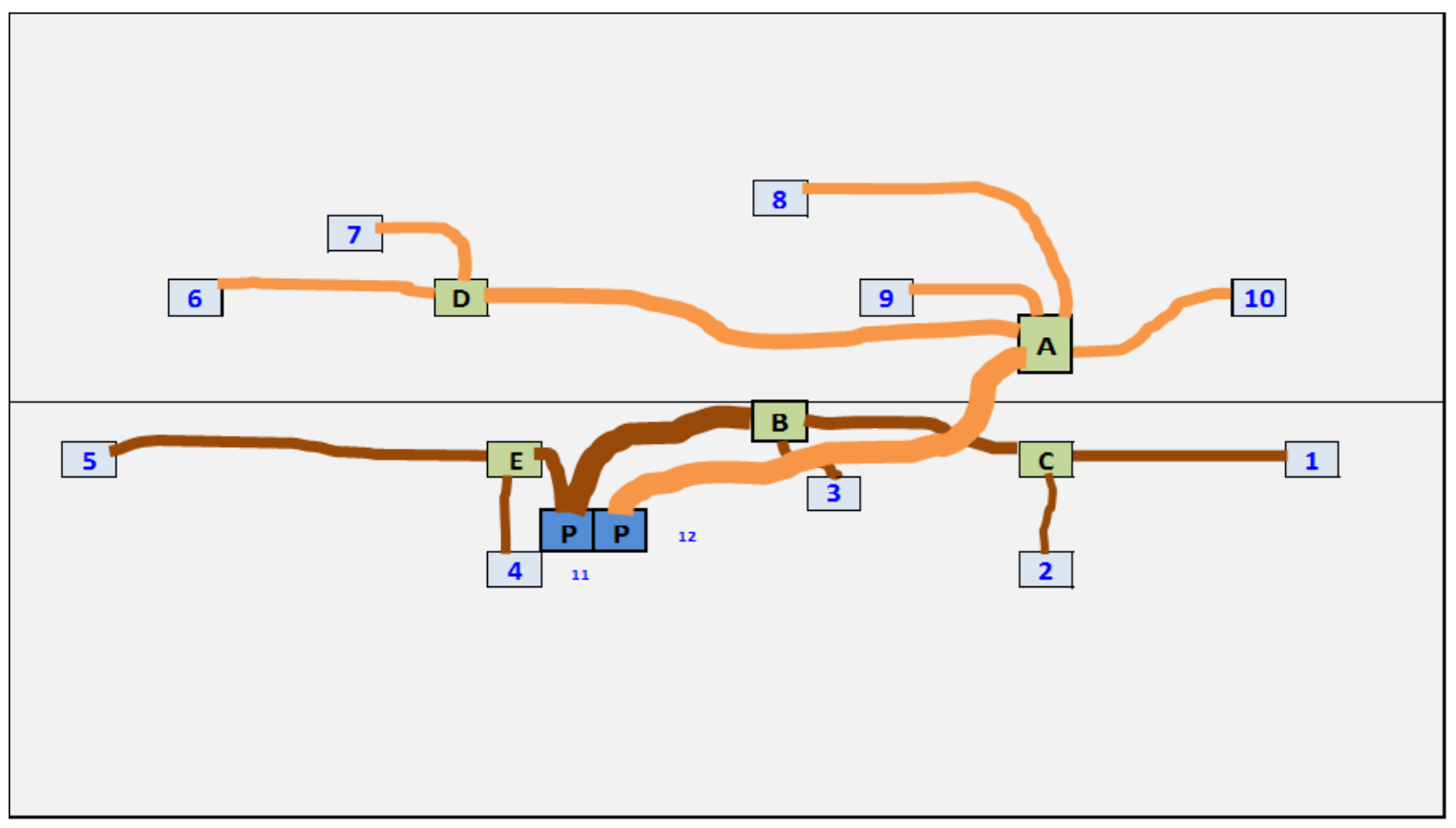

Figure B-4. Attic duct layout with element IDs shown

The following table lists the elements from the duct layout used in the calculation procedure. The Duct IDs in Table B-4 correspond to the identifiers shown in Figure B-4. The first six measured temperatures at the bottom of Table B-1 were taken before the retrofit and the last five were measured after the retrofit. 
Table B-1. The Input Elements Used in Calculating the Effective R-value of the Lab Duct System Before and After Adding Insulation to Attic Ducts

\begin{tabular}{|c|c|c|c|c|c|c|c|c|c|c|c|c|c|c|c|c|c|}
\hline $\begin{array}{l}\text { Variables Names } \\
\end{array}$ & & UNITS & & & & & & & & & & & & & & & \\
\hline Barometric Pressure & & $\mathrm{kPa}$ & 101.52 & & & & & & & & & & & & & & \\
\hline Number of Ducts & & - & 15 & & & & & & & & & & & & & & \\
\hline Duct Index & & - & 1 & 2 & 3 & 4 & 5 & 6 & 7 & 8 & 9 & 10 & 11 & 12 & 13 & 14 & 15 \\
\hline Duct ID & & - & $1 \mathrm{C}$ & $2 \mathrm{C}$ & 3B & $4 \mathrm{E}$ & $5 E$ & $6 \mathrm{D}$ & 7D & $8 \mathrm{~A}$ & $9 \mathrm{~A}$ & $10 \mathrm{~A}$ & $\mathrm{BC}$ & PB & DA & PA & $\mathrm{PE}$ \\
\hline Air Volume Flow Rate & & $\mathrm{cfm}$ & 51.0 & 31.0 & 34.0 & 40.0 & 45.0 & 76.0 & 35.0 & 39.0 & 31.0 & 41.0 & 82.0 & 116.0 & 111.0 & 222 & 85 \\
\hline Duct Surface Area & & $\mathrm{ft}^{2}$ & 18.8 & 6.3 & 7.3 & 10.5 & 45.9 & 35.3 & 9.4 & 37.7 & 13.6 & 9.4 & 36.8 & 46.9 & 84.6 & 89.2 & 12.6 \\
\hline Duct Inside Diameter & & in & 6 & 5 & 5 & 5 & 6 & 8 & 6 & 6 & 5 & 5 & 8 & 12 & 10 & 12 & 8 \\
\hline Duct Outside Diameter & & in & 9 & 8 & 8 & 8 & 9 & 11 & 9 & 9 & 8 & 8 & 11 & 15 & 13 & 15 & 11 \\
\hline Duct Buried Fraction & & - & 0.0 & 0.0 & 0.0 & 0.0 & 0.0 & 0.0 & 0.0 & 0.0 & 0.0 & 0.0 & 0.0 & 0.0 & 0.0 & 0.0 & 0.0 \\
\hline Number of Duct Run Paths & & - & 10.0 & & & & & & & & & & & & & & \\
\hline & & 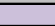 & ndex of the $d$ & Run Path foll & owed by the in & dices of the du & ts along & t t run $p$ & Index of & t run $\mathrm{pa}$ & he inde & he last $c$ & section & g a duct $n$ & path. & & \\
\hline Duct Run Path Index & & - & 1 & 2 & 3 & 4 & 5 & 6 & 7 & 8 & 9 & 10 & & & & & \\
\hline & 1 & & 12 & 12 & 12 & 15 & 15 & 14 & 14 & 14 & 14 & 14 & & & & & \\
\hline & 2 & 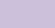 & 11 & 11 & 3 & 4 & 5 & 13 & 13 & 8 & 9 & 10 & & & & & \\
\hline & $\begin{array}{l}3 \\
4\end{array}$ & & 1 & 2 & & & & 6 & 7 & & & & & & & & \\
\hline Boundary Condition & & - & Average & & & & & & & & & & & \multirow{3}{*}{\multicolumn{3}{|c|}{ Calc-Effective-RValue }} & \\
\hline Duct Surface Emissivity & & - & 0.60 & & & & & & & & & & & & & & \\
\hline Attic Surface Emissinty & & - & 0.90 & & & & & & & & & & & & & & \\
\hline \multirow[t]{13}{*}{ Measured Data Points } & & - & Attic Air & Attic Surface & $\begin{array}{l}\text { Conditioned } \\
\text { Space }\end{array}$ & $\begin{array}{l}\text { AHU Leaving } \\
\text { Air }\end{array}$ & 1 & 2 & 3 & 4 & 5 & 6 & 7 & 8 & 9 & 10 & \\
\hline & & - & & & & & $1 \mathrm{C}$ & $2 \mathrm{C}$ & 3B & $4 \mathrm{E}$ & $5 E$ & 60 & 70 & $8 \mathrm{~A}$ & $9 \mathrm{~A}$ & $10 \mathrm{~A}$ & \\
\hline & 1 & ${ }^{\circ} \mathrm{F}$ & 108.2 & 123.3 & 78.0 & 58.6 & 66.0 & 65.4 & 63.0 & 64.1 & 69.2 & 67.8 & 67.8 & 66.9 & 63.1 & 63.4 & \\
\hline & 2 & ${ }^{\circ} \mathrm{F}$ & 108.3 & 123.9 & 78.0 & 59.2 & 66.4 & 65.9 & 63.4 & 64.6 & 69.7 & 68.3 & 68.3 & 67.4 & 63.6 & 63.9 & \\
\hline & 3 & ${ }^{\circ} \mathrm{F}$ & 109.1 & 124.4 & 78.0 & 59.4 & 66.7 & 66.2 & 63.7 & 64.8 & 70.0 & 68.6 & 68.6 & 67.7 & 63.9 & 64.2 & \\
\hline & 4 & ${ }^{\circ} \mathrm{F}$ & 109.8 & 125.1 & 78.0 & 59.5 & 67.1 & 66.4 & 64.0 & 65.1 & 70.3 & 68.8 & 68.9 & 67.9 & 64.1 & 64.4 & \\
\hline & 5 & ${ }^{\circ} \mathrm{F}$ & 110.5 & 125.2 & 78.0 & 59.4 & 67.2 & 66.4 & 64.0 & 65.1 & 70.3 & 68.8 & 68.9 & 67.9 & 64.1 & 64.3 & \\
\hline & 6 & ${ }^{\circ} \mathrm{F}$ & 109.5 & 123.6 & 78.0 & 59.6 & 67.2 & 66.5 & 64.0 & 65.3 & 70.3 & 68.8 & 68.9 & 68.0 & 64.2 & 64.3 & \\
\hline & 7 & ${ }^{\circ} \mathrm{F}$ & 111.5 & 126.5 & 78.0 & 58.7 & 63.4 & 64.0 & 61.8 & 63.2 & 66.3 & 65.3 & 66.2 & 65.0 & 62.1 & 61.7 & \\
\hline & 8 & ${ }^{\circ} \mathrm{F}$ & 110.6 & 123.2 & 78.0 & 60.6 & 64.5 & 64.6 & 63.4 & 64.6 & 67.5 & 65.7 & 66.1 & 65.5 & 63.5 & 63.0 & \\
\hline & 9 & ${ }^{\circ} \mathrm{F}$ & 110.4 & 123.6 & 78.0 & 58.3 & 62.4 & 62.2 & 60.6 & 62.4 & 66.6 & 64.3 & 65.0 & 64.0 & 61.0 & 60.7 & \\
\hline & 10 & ${ }^{\circ} \mathrm{F}$ & 113.7 & 129.5 & 78.0 & 60.1 & 64.1 & 65.3 & 63.7 & 64.0 & 66.7 & 65.5 & 66.6 & 65.4 & 63.6 & 62.7 & \\
\hline & 11 & ${ }^{\circ} \mathrm{F}$ & 112.2 & 126.4 & 78.0 & 58.1 & 62.6 & 62.0 & 60.3 & 62.5 & 66.7 & 64.5 & 65.0 & 63.9 & 60.7 & 60.7 & \\
\hline
\end{tabular}

Round duct surface areas were calculated based on measured inner diameter, outer duct circumference and outer duct length. Duct box dimensions were also measured. The calculated surface-to-surface R-value calculation results are shown in Figure B-5 and are discussed in more detail in Section 2.4. 


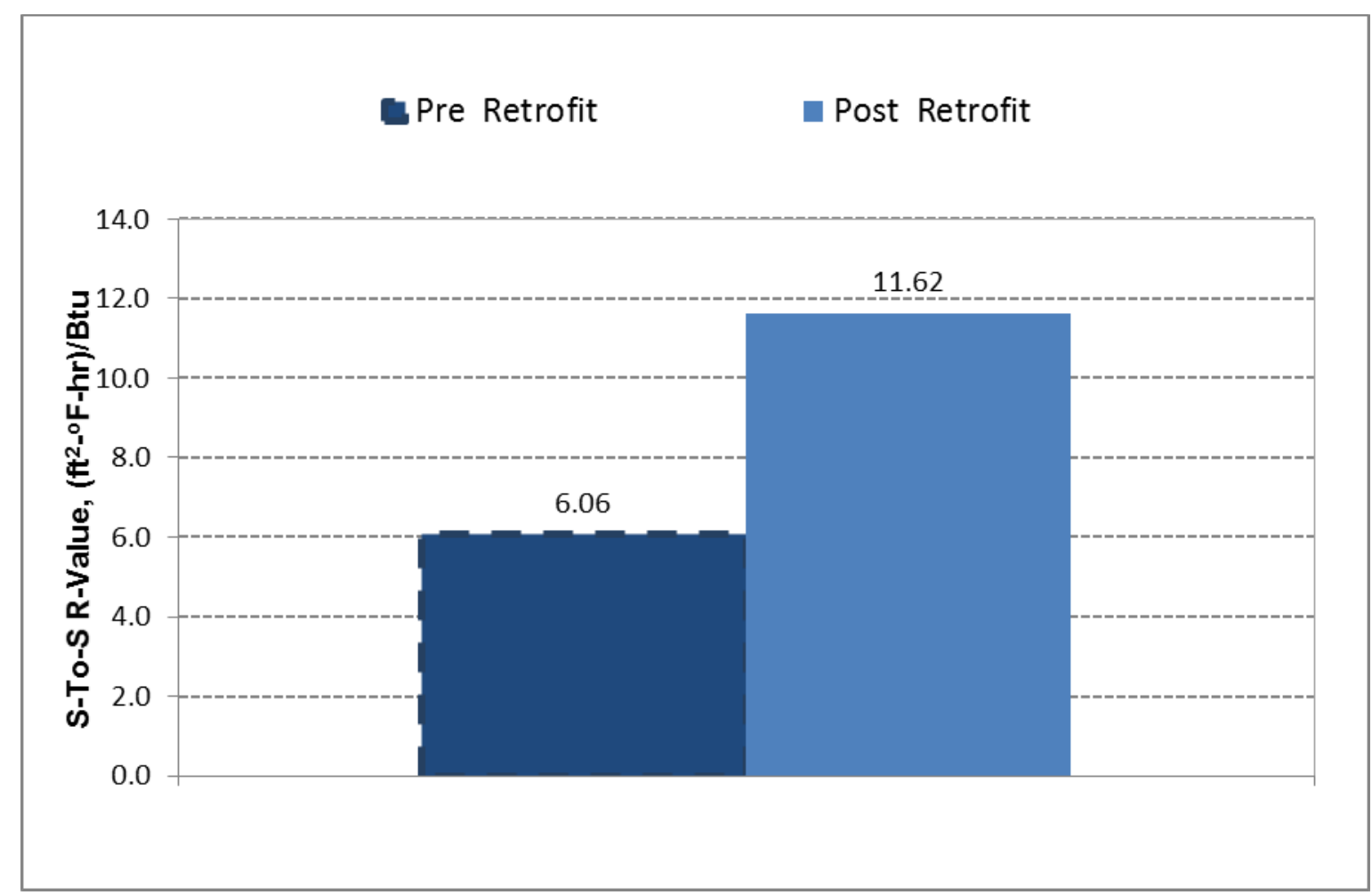

Figure B-5. Resulting calculated effective duct surface to surface R-Values before and after adding insulation wrap to attic ducts 


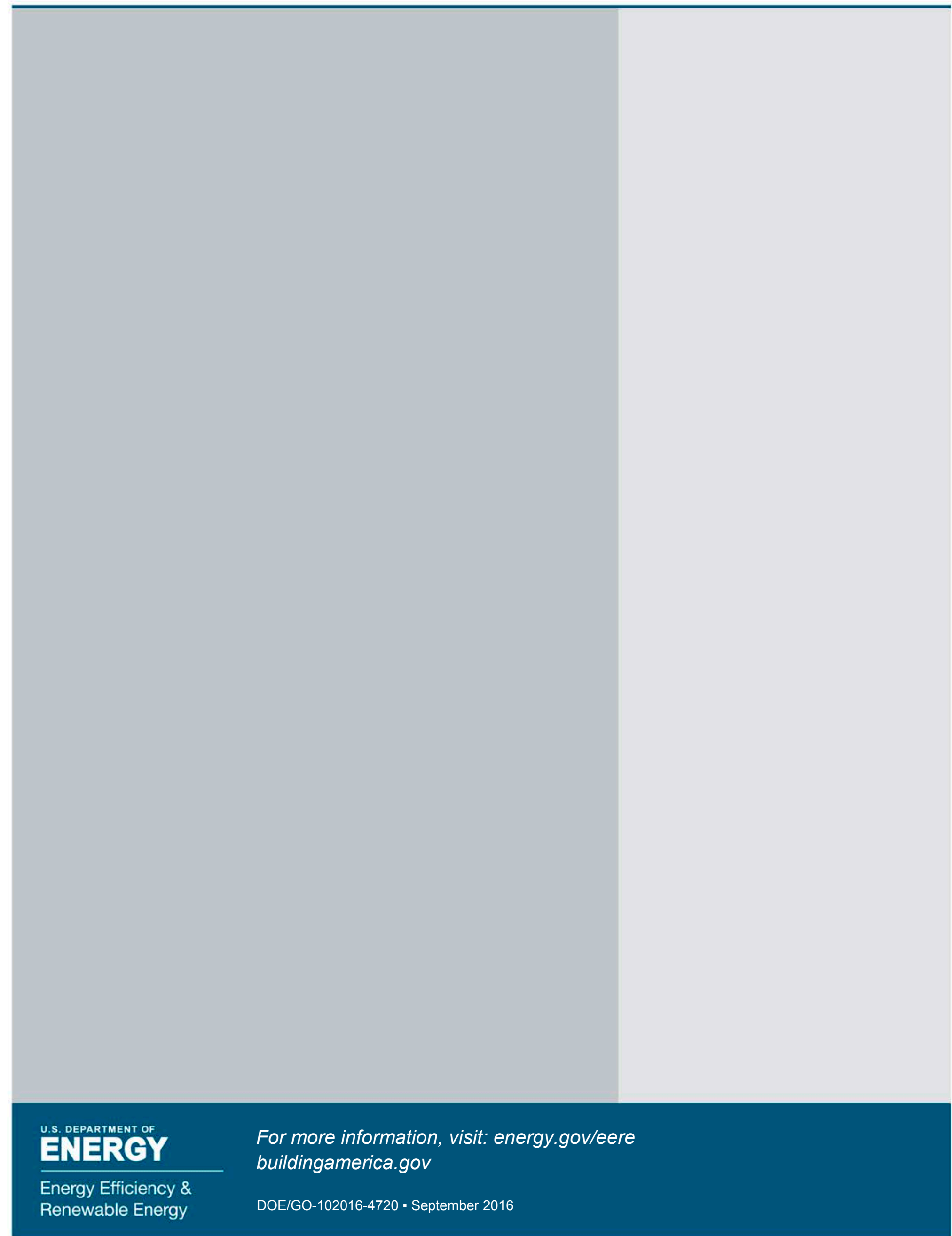

